\title{
GEOLOGY OF CASS COUNTY
}

JOHN L. TILTON 
$\cdot$ 


\section{CONTENTS}

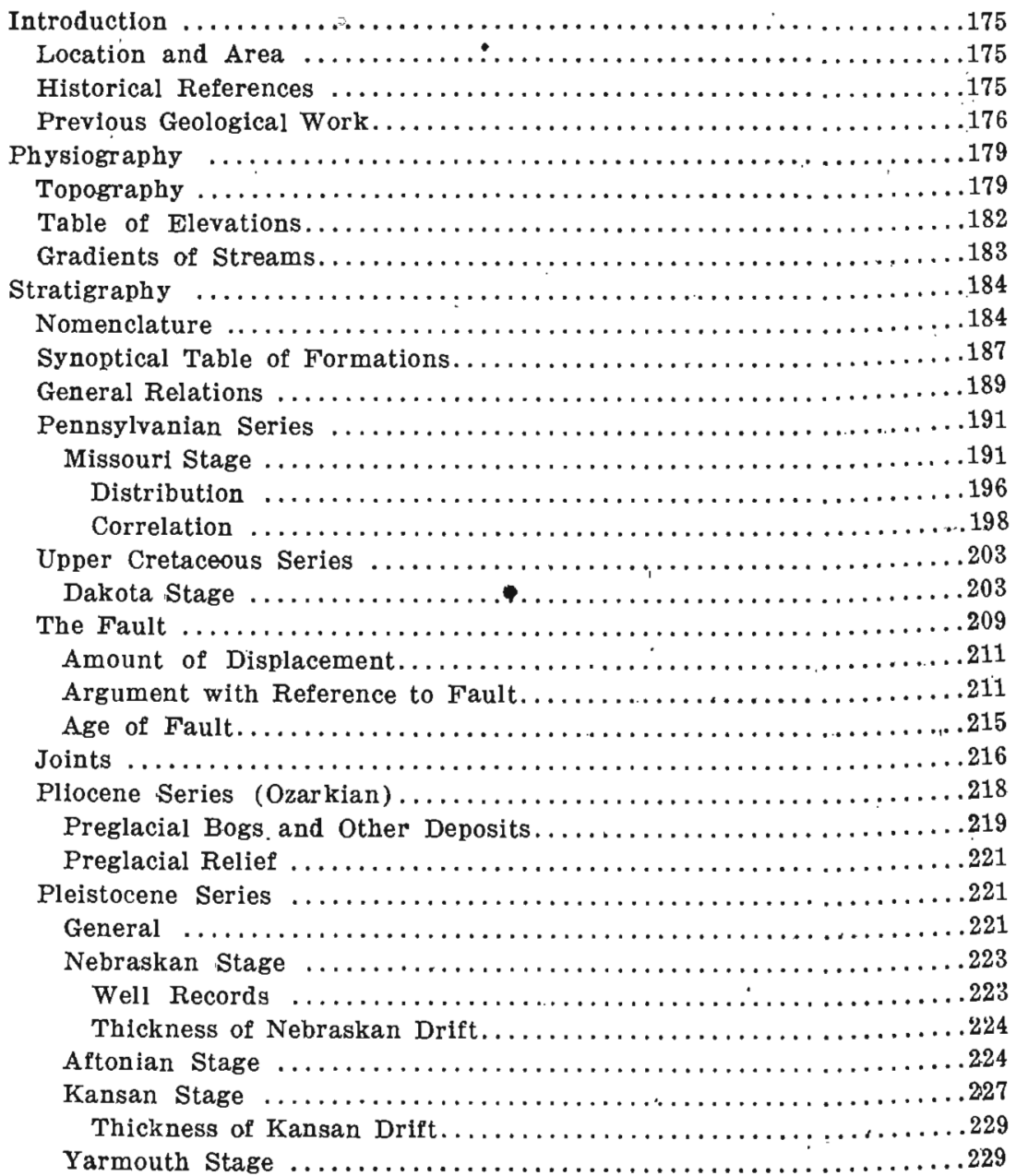

(173) 


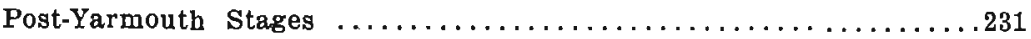

The Sand beneath the River Beds....................231

The Sand beneath the Loess. . . . . . . . . . . . . . . . 232

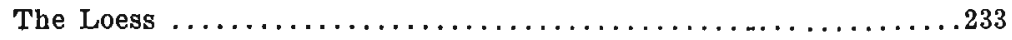

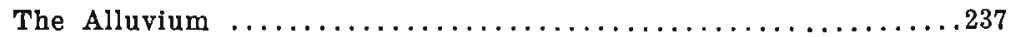

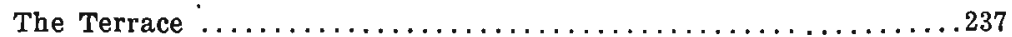

The Sequence of Post-Yarmouth Events................. 237

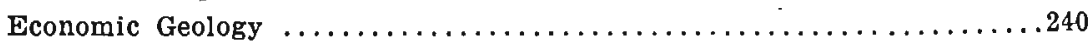

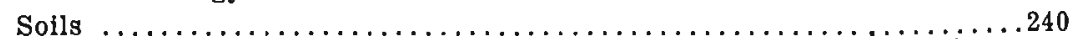

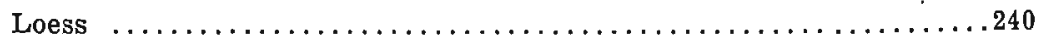

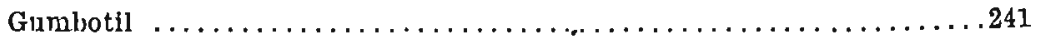

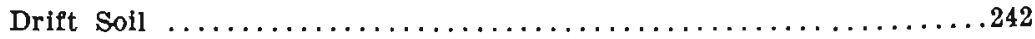

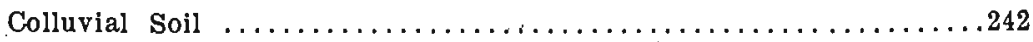

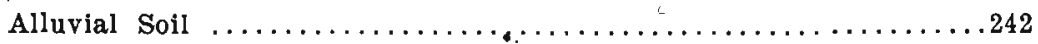

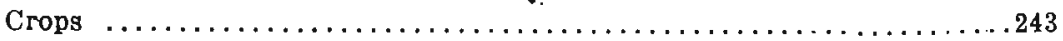

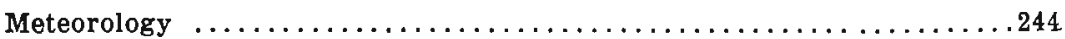

Native Flora and Fauna............................

Some of the Common Plants.......................... 248

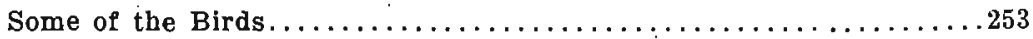

Water for Farm Use.............................. 254

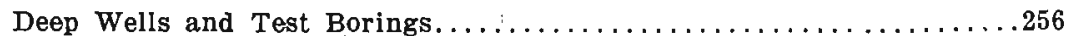

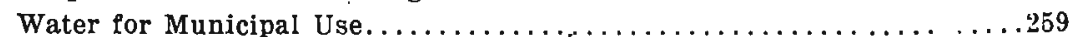

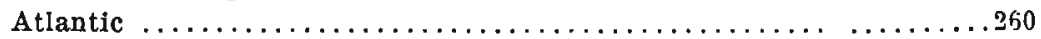

Significance of Water Analyses.......................

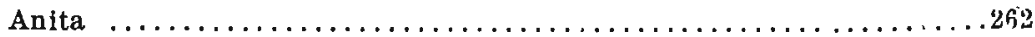

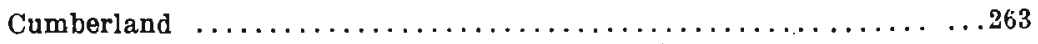

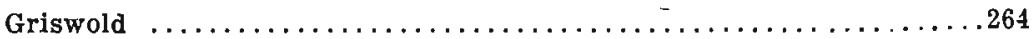

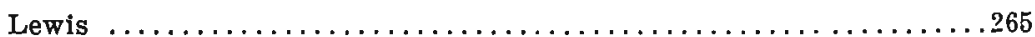

Marne ....................................

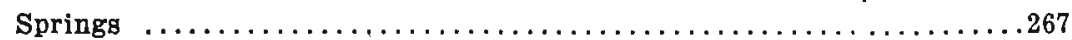

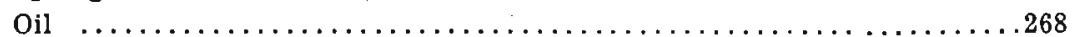

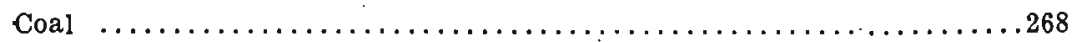

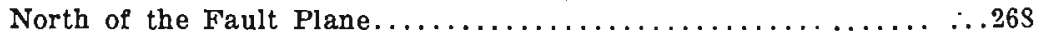

South of the Fault Plane.........................

Well Records with Reference to Coal....................276

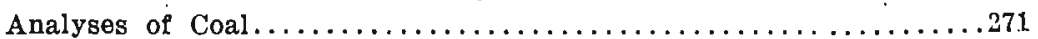

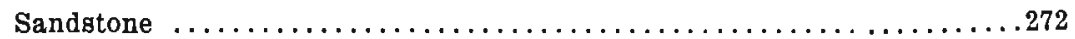

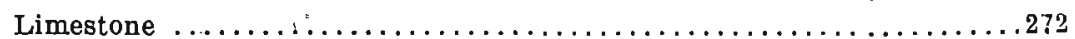

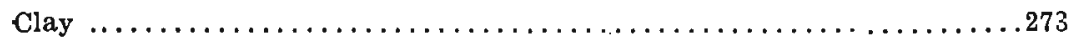

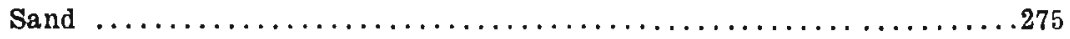

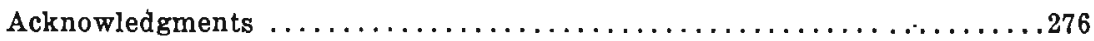




\section{GEOLOGY OF CASS COUNTY}

\section{INTRODUCTION}

Location and Area.-Cass county is the second east of the Missouri river and the third north of the Iowa-Missouri line. It includes Townships 74 to 77 North and Ranges XXXIV to XXXVII west of the Fifth Principal Meridian. Its 576 square miles divided into sixteen full townships of rich farm land surround its enterprising towns of Atlantic, Wiota, Anita, Marne, Lewis, Griswold, Cumberland and Massena, among which Atlantic has an enviable reputation as one of the best business centers between Des Moines and Council Bluffs.

Historical References.-A mile west of Lewis is the site of old Indiantown, located beside a former chief village of the Pottawattamie Indians. The former beautiful spring nearby where the Indians got their water from the base of a sandstone bluff is now a watering place in a pasture. Of the numerous graves on the hillsides scarcely a mound can now be seen. South of Lewis another beautiful center of Indian life is still a gem in scenery: Crystal Lake. Just south of the center of the county is the line of the old trail north of Cumberland, to the ford at Lewis, and then west, on toward Council Bluffs. On the hill-

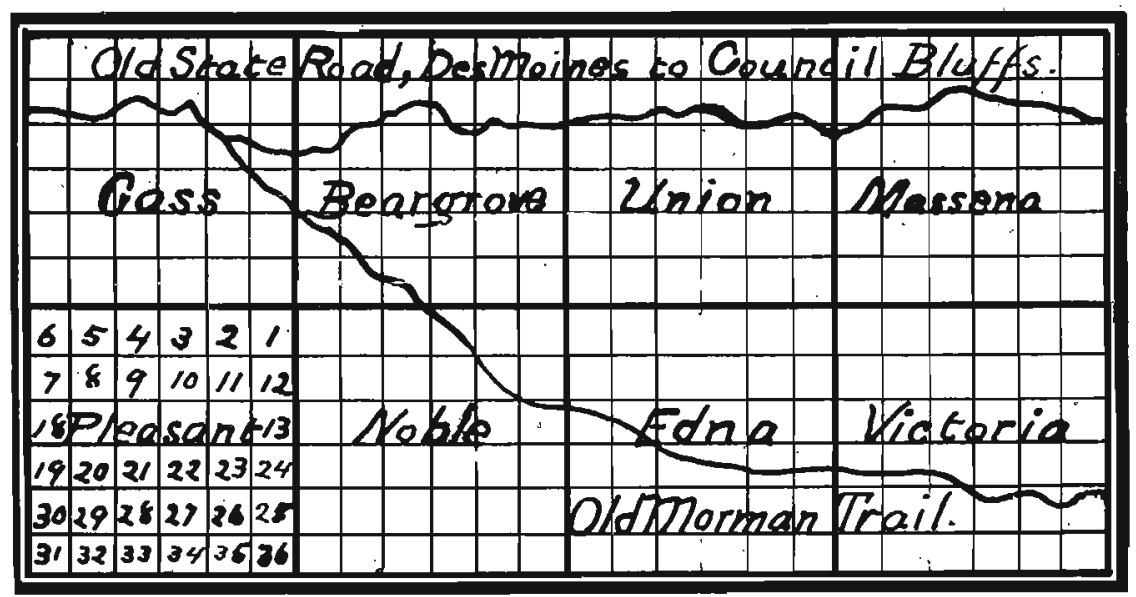
Fig. 22.- Early trails across Cass county, located by Mr. Charles H. Rhode of Cum-
berland. 
side at the ford the wheel ruts are still visible winding up the steep bank from the ford below the mill at Lewis Now this line of early travel is unused, for the main line of the Chicago, Rock Island and Pacific Railway crosses the northern half of the county.

Previous Geological Work.-When David Dale Owen had completed his trip up Des Moines river to study the formations along that river for a report to Congress he sent his party with the canoes and collections down the river from Des Moines while he himself took a hasty trip along the old trail from Des Moines to Council Bluffs. He mentions crossing North river, Middle river, Clanton creek, Grand river, two branches of the Nodaway, and the East, Middle and West branches of Nishnabotna river. It was only on the latter stream that any rock were found in place, for the old trail avoided the rough ground, where in a few places stratified rocks were to be seen. The brief mention that he gives of the soft brown sandstone and of three beds of limestone, "the intervening faces between the beds are hidden from view," make it evident that he crossed the East Nishnabotna at Lewis. In his further statement that "a light colored gritstone is found in a grove one mile east of the same stream" he undoubtedly refers to the "Crystal Lake" bluffs near Lewis.

The work of James Hall and of James D. Whitriey described in the "Report on the Geological Survey of the State of Iowa," 1858 , was chiefly upon the eastern portion of the state, work upon the western portion having been discontinued because the people were not then awake to the need and the magnitude of the undertaking. The views of those early geologists as they extended their work westward are worthy of note: "The formations throughout the southern, eastern and central parts of the state, are all of such a character as to produce soils of immense agricultural capacities; and the geological structure of the state clearly indicates that her agricultural products, her coal mines, and beds of gypsum, will constitute her greatness of resources and her future wealth." "In the preceding paragraph they also stated that, "All the intermediate rocks are

${ }^{1 H a l l}$ and Whitney, "Report on the Geological Survey of the State of Iowa," p. 145,1858 . 
more or less calcareous, affording an abundance of lime and ordinary building stone, and some of them hydraulic cement." As they glanced westward in the state they called attention to the possible relation of strata here to strata on which some work had been done in Missouri and along the eastern slope of the Rocky Mountains. Already the peculiar distribution of the flora had attracted their attention, leading to the great problems of the loess and gumbo on which problems considerable work has since been necessary to lead to an understanding of their relations. They approached their problems from a study of conditions in Michigan where the treeless areas were sites of former lakes now filled with silt, and they suspected that the prairie regions to the south and west also were of this origin, and were drained and trenched during a later upheaval. ${ }^{2}$ White in 1870 quotes ${ }^{3}$ this view of Hall, and proceeds to describe the distribution of this "bluff deposit" over western Iowa, especially along a line across the northcentral part of the state. That he recognized a "gumbo" as distinct from a loess is evident in his contrast of the upland soil of southcentral Iowa with the soil of the ground moraine in the northeentral part and the so-called "bluff deposit," or loess, of the western part of the state. His judgment was influenced by the prevailing view of the time that there was but one glacial drift, ${ }^{4}$ which was that most abundantly found in the northcentral part of the state. Evidently his thick "bluff deposit" of the western part of the state included both the loess and the upper gumbo (Kansan gumbotil).

White erroneously correlates the limestone and adjacent shale found at Lewis ${ }^{5}$ with numbers 6 to 9 inclusive of his Winterset section, ${ }^{\circ}$ and mentions the coal ${ }^{7}$ farther south as included in 6 to 10 of his Winterset section. He thought that this seam of coal, six inches thick on the average, lay in an approximately horizontal position within the area of a large triangle south of Cass county, which horizontal plane continued northward is 
near the level of the beds of the streams in southern Cass county. The plan that he outlines for determining the facts with reference to the presence of coal ${ }^{8}$ has in part been carried out, and some information is now obtainable from borings. Dr. George L. Smith has since done much toward deciphering the peculiar relation of strata in the southwestern part of the state. White's greatest contribution to the knowledge of the possible distribution of coal was his proof that the coal did not lie in a great basin bounded on the east by the Burlington limestone, and on the west by the same bed of limestone outcropping at Winterset. By a careful study of the fossils he ascertained that these limestone beds at Winterset (and farther west in the area including Cass county) were far above, and thus younger in age, than the beds at Burlington, ${ }^{9}$ and that they dipped to the south in the southern part of the state. Hence it was possible that seams of coal such as were mined near Des Moines might exist southwest beneath those limestone beds in the western part of the state, though they would be too deep for exploitation for many years.

The sandstone near Lewis White recognized as Cretaceous in age and gave it the provisional local name, "Nishnabotna sandstone, ${ }^{10}$ though on comparing it with sandstone found farther west in the country, he stated that he had no "doubt that the lowest portion of ours is equivalent to a part of their Dakota group." The name Nishnabotna sandstone persisted till Calvin brought forward the final proof and substituted the general name, Dakota sandstone, for the local name. ${ }^{12}$ Bain, at work in Guthrie county, also referred to the Dalrota sandstone, which extends eastward into that county. It was thus fully recognized that these brown and white sandstones are a part of the extensive beds that are known to exist far to the west beneath the "great plains," even to the Rocky mountains.

In volume XIX of the Iowa freolngical Survey may be found a vàluable paper by George I. Smith, M. I., on "The Carboniferous Section of Southwestern Iowa," in which outcrops to the south of Cass county are described. Farther to the south in

\footnotetext{
sIdem. Vol. I, pp. 258-263, and 314

Idem. Vol. I, pp. 243-244.

10Idem Vol. I. p. 289.

u Idem. Vol. I, pp. $2 \dot{8} 9$. See also p. 286, recognizing Jules Marcou as the first to recognize the presence of Cretaceous strata in Iowa.

${ }_{12} \mathrm{~S}$. Calvin, Amerícan Geologist, Vol. Ir, p. 300.
} 
Missouri there is a series of outcrops of these same beds which have been recently described by Hinds and Greene in volume 13 of the Missouri Bureau of Geology and Mines: "The Stratigraphy of the Pennsylvanian Series in Missouri," thus continuing the work of Broadhead. On pages 1117 to 11 ? 4 of volume XXI of the Towa Geological Survey may be found the data reported by H. E. Simpson and W. H. Norton in their work upon the "Underground Water Resources of Iowa."

As work upon the present survey progressed the study of Cass county was assigned to James Eillis Gow, who had then just completed the study of Adair county. The study of Cass county was nearly completed by Mr. Gow and the work of writing up the report had just been begun when his death occurred. So little of the manuscript was completed (five pages) that a complete resurvey was necessary. This work was assigned to the present writer, who has devoted the summers of 1916 and 1917 to the problems.

In the last few years much has been done to differentiate the various drift sheets and to study the interglacial deposits throughout the state. That which is of greatest value for use in Cass county has to do with the recognition of a Nebraskan till plain that appears on the hillsides of the deepest valleys in the counity, and with the causes that have operated to produce the Nebraskan gumbotil, and also the upper, or Kansan, gumboti ${ }^{13}$. A paper will soon be published by G. F. Kay and J. N. Pearce in which the origin of gumbotil from the standpoint of investigations in the field and in the chemical laboratory will be discussed fully.

\section{PHYSIOGRAPHY}

\section{Land Form}

Topography.-The upland of Cass county is a part of an extensive drift plain sloping gently toward the southwest and trenched by streams that flow south and southwest and mantled by loess. Each of the large valleys has a well developed flood plain bordered by a conspicuous terrace.

13Kay, George F. "Gumbotil. A New Term in Pleistocene Geology;" Science, New Serics, Vol. XLIV, Nov. 3,1916 . 
Along the east side of the county the West Nodaway and various tributaries rise close to the county line and drain the southeastern half of the county. Flarther north Turkey creek heads a rew miles east of the northeast corner of the county, along the crest of the great divide of Iowa that separates the area drained to the Mississippi from that drained to the Missouri. Troublesome creek and East Nishnabotna river rise farther away along the same divide in the east and northern portions of Audubon coupty. Indian creek, flowing south near the west county line, rises at a distance from the divide and drains the area between the East Nishnabotna and the East Fork of the West Nishna-

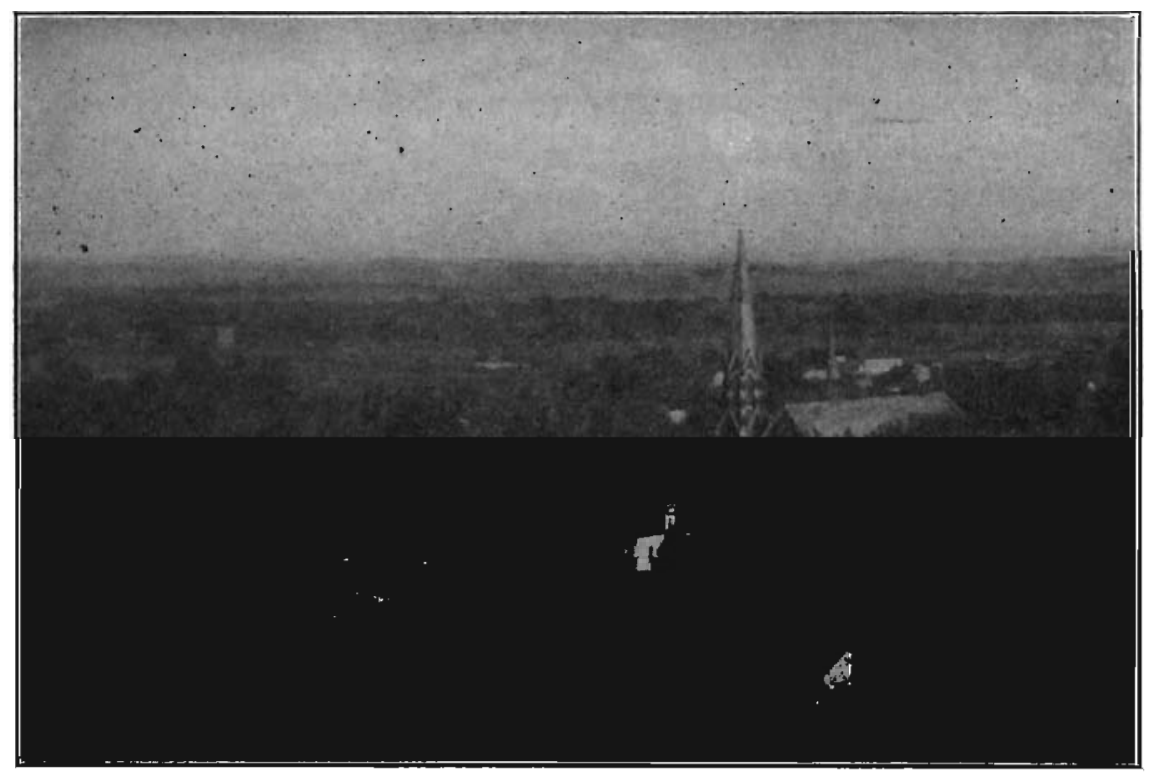

FIG. 23.-View looking northwest across the valley of Nishnabotna river from the dome of the Court House at Atlantic, Cass county.

botna. With this arrangement of streams there is a corresponding gradation in the topography. Along the eastern portion of the eounty the surface is rolling. If one follows down the streams of this region the valleys are seen to be progressively deeper and broader to the south and southwest. The deeper and broader portions of each valley contain not only a flood plain but also a low terrace, or second bottom. Along Turkey, Troublesome and Indian creeks, and especially along the East Nishna- 
botna, the chief streams of the county, the flood plain is very conspicuous and is bounded by lines tangential to the outside curves of a broad meander belt. Along East Nishnabotna river and Indian creek flooding is now diminished by drainage canals. Bordering these flood plains is a low terrace eight feet above the flood plain. South of Lewis to the county line this terrace broadens out to a conspicuous plain from one to three miles wide. North of Lewis even to the north county line it broadens out in places to a width of a mile.

The slopes from the Kansan upland plain down toward the bottom land along the rivers in the southwest third of the county

\section{Cass Councy.}

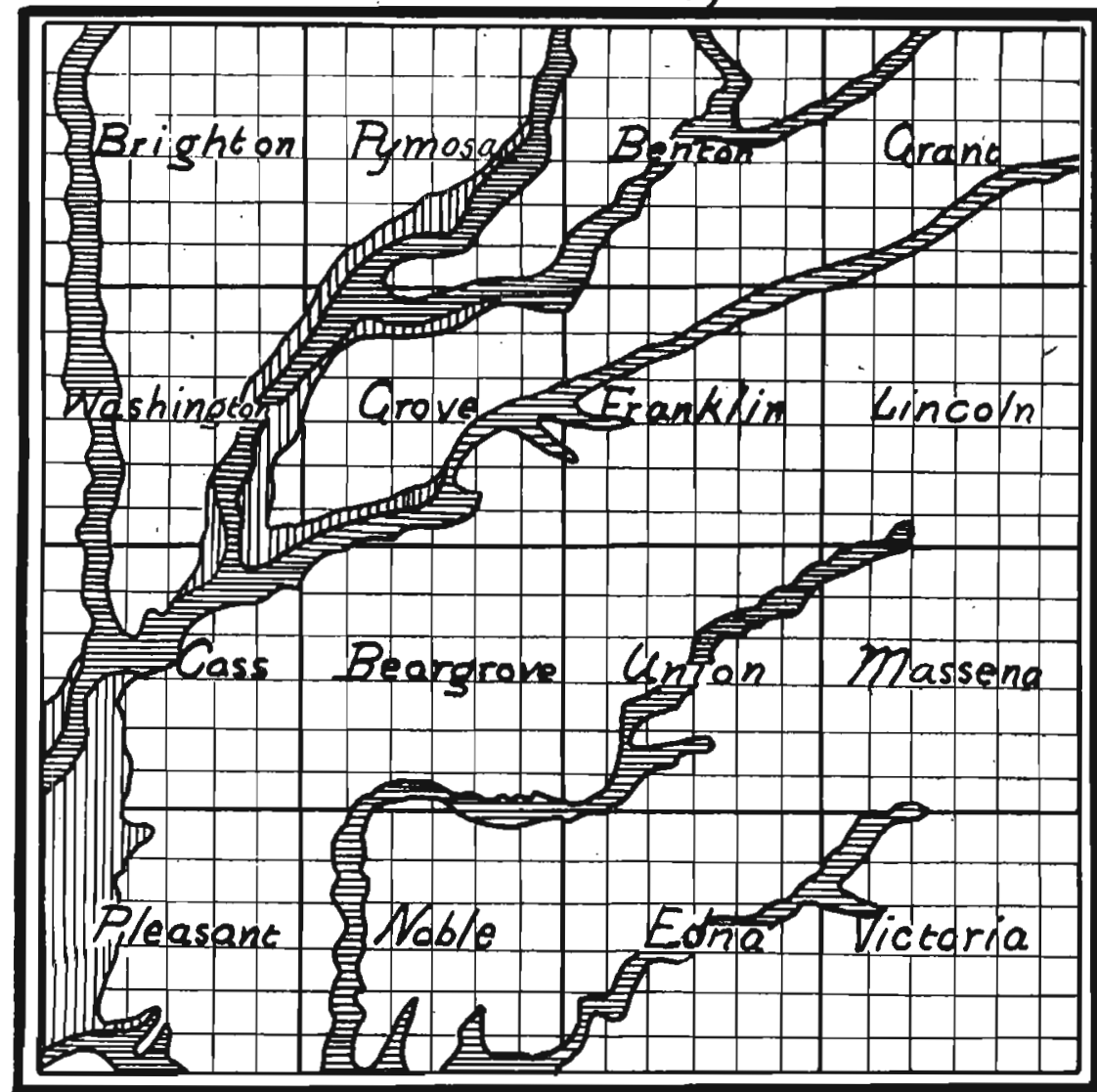

Terrace.

Fia. 24-Flood plains and terraces where these are conspicuous in Cass county. 
are broken in a peculiar and interesting manner by a few small but picturesque nooks along cliffs of sandstone, parts of a topography of a bygone age that have been brought to light by erosion of drift that had concealed them. One stretch of such scenery lies along the west side of the river west and northwest of Griswold, just west of the county line. Another is at Spring oreek, a mile west of Lewis. A third, and the most beautiful of all, is south of Lewis at Crystal Lake, and along the line of the old quarry on the east side of the road near by. A fourth is in section 33 of Beargrove township, and a fifth is in section 31 of Noble township. Several smaller outcrops of this sandstone are to be found, but these five are little gems of scemlery adding beauty to the topography by contrast. In a few places the regular profiles of valleys eroded in drift are broken by ledges of limestone that, like the sandstone, have been discovered by erosion of the drift. The most conspicuous disclosure is at Lewis, where the limestonie is the site of a dam for water power, and a mile further west where Spring creek falls over a low ledge near the road. Old quarry faces rise above the stream in saction 36 of Noble township and 31 of Edna township.

The relief for the county as a whole is about 360 feet. Along the eastern side of Lincoln township the local relief is slight. It increases in amount west and south till it reaches a maximum in the southwest quarter of the county. It is most rugged along the south county line, which crosses the streams and divides at right angles, where valleys are deepest.

TABLE OF ELEVATIONS

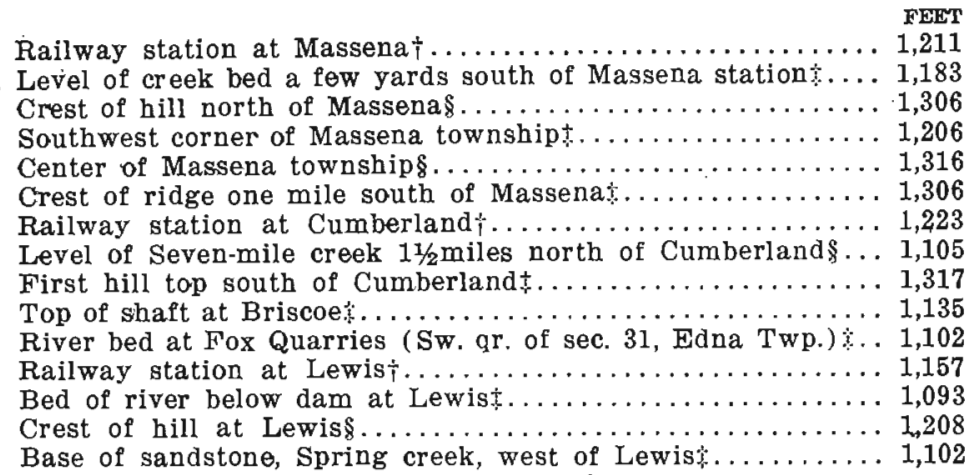


Bed of Spring creek west of Lewist..............

Railway station at Griswold $\ldots \ldots \ldots \ldots \ldots \ldots \ldots \ldots \ldots, 0, \ldots \ldots$

Bed of river west of Griswold $\ldots \ldots \ldots \ldots \ldots \ldots \ldots \ldots \ldots, 076$

Railway station at Marne*.................. 1,194

Abutment of bridge 444,3 miles east of Marne*.......

Railway station at Atlantic $\ldots \ldots \ldots \ldots \ldots \ldots \ldots \ldots \ldots \ldots \ldots, 1,160$

Bed of river west of Atlantic $\ldots \ldots \ldots \ldots \ldots \ldots \ldots \ldots \ldots \ldots, 124$

Bed of Turkey creek south of Atlantic (se. qr. sec. 28, Grove

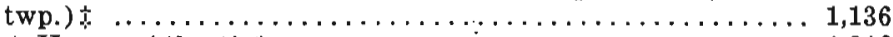

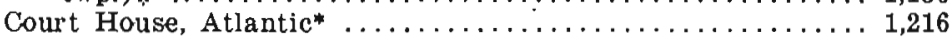

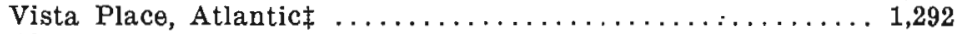

Abutment of R. R. bridge 440 , 1/2 mile east of Atlantic $\ldots \ldots$. . 156

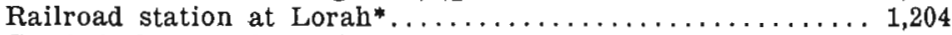

Creek bed east of Lorah $\neq \ldots \ldots \ldots \ldots \ldots \ldots \ldots \ldots \ldots \ldots, 1,184$

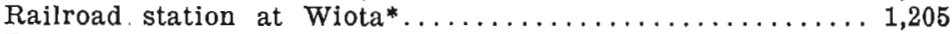

Bed of Turkey creek at Wiota.................. 1,185

Railway station at Anita*....................... 1,258

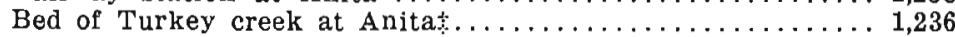

Railroad culvert one mile west of Anita* ........... 1,244

Railroad culveri three miles west of Allita ............. 1,238

Base of Missouri limestone Eureka shaft, southeast of Anita 1,198

Rellef, section 7, Brighton township $\$ \ldots \ldots \ldots \ldots \ldots \ldots \ldots \ldots$

Relief, section 1, Benton townshipt............... 125

Relief, sections 15-16, Benton township $\ldots \ldots \ldots \ldots \ldots \ldots \ldots . \ldots \ldots$

Relief, section 35, Franklin township

Relief, three miles south of Anita $\neq \ldots \ldots \ldots \ldots \ldots \ldots \ldots \ldots \ldots . \ldots \ldots$

" "Spirit Levelling in Iowa", Bull. 460, U. S. G. S

†Gannet's "Dictionary of Aititudes," Buli. 274, U. S. G. S.

Barometric data by James Ellis Gow.

$\ddagger$ Barometric data by John L. Tilton.

GRADIENTS OF STREAMS

Lorah to Atlantic

$\begin{array}{ccc}\text { DISTANCE } & \text { TOTAL FAII } & \text { FALL PEB } \\ \text { MILES } & \text { FEET } & \text { MILE, FEET } \\ 61 / 4 & 60 & 9.6 \\ 11 . & 31 & 2.8 \\ 21 . & 48 & 2.3 \\ 10 . & 17 & 1.7 \\ 21.1-3 & 50 & 2.3 \\ 7.1-3 & 29 & 4 . \\ 4 & 4 & 1 . \\ 7 & 51 & 7.3 \\ 12 . & 100 & 8.1-3 \\ 8.5 & 103 & 12.1 \\ 10.5 & 181 & 17 .\end{array}$

Atlantic to Lewis...............

Atlantic to Griswold............. 21

Lew is to Griswold ............ 10

Lew is to Stennett . . . . . . . . . . . 21.1-3

Griswold to Elliott............. $7.1-3$

Elliatt to Stennett....................

Anita to Wiota ...............

Wiota to Lewis......................... 12

$\begin{array}{lr}\text { Cumberland to Fox Quarry......... } & 8.5 \\ \text { Massena to Fox Quarry........... } & 10.5\end{array}$

The gradients of the streams given in the table are based on data from the sources named in the Table of Elevations. Dis-

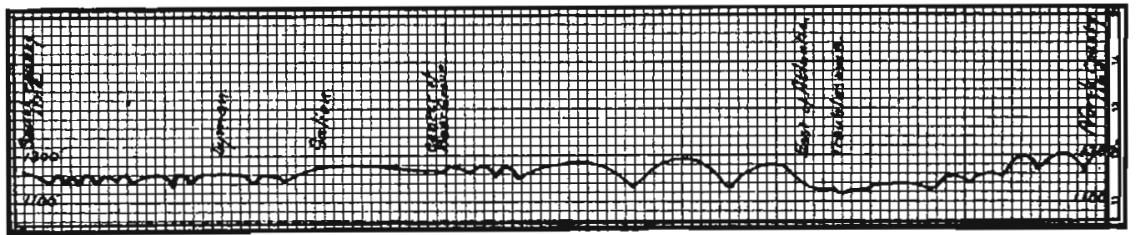

Fig. 25-An approximate profile north and south through the centers of Pymosa. Grove, Beargrove and Noble townships, Cass county. 
tances are measured along straight lines from one location to another; those along the Nishnabotna were projected on one straight line used as a base line.

The comparatively high gradient in the eastern and northeastern part of the county is partly due to the winding course of the streams, which increases considerably the actual distance the water flows, and partly due to the steeper gradient of the erosional curve in the upper course of a stream. There is but one break in the gradient, which is at the dam eight feet high at Lewis.

The origin of the topography is best considered in connection with the various deposits, especially those of the Kansan and post-Kansan stages. It should be noted that prior to the present

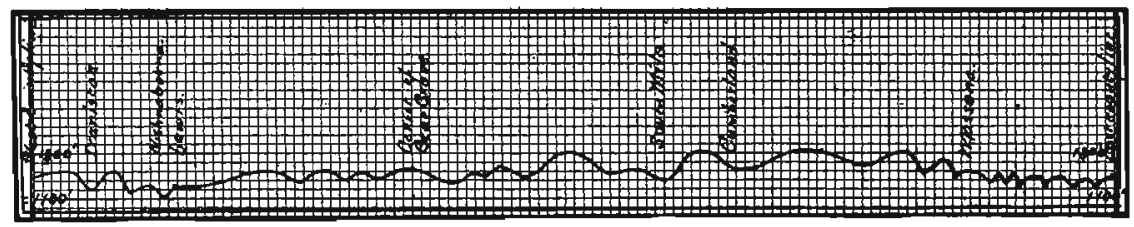

FIG. 26.-An approxlmate profle west by north on a stralght line through Massena, Cumberland, Lewis, and Iranlstan, Cass county.

landscape on which we live there have been within the limits of Cass county and on the deposits here described, three landscapes preceding the present one. These four landscapes are as follows:

1st. On the Missouri limestone and shale, that are chiefly of marine origin.

2nd. On the Dakota sandstone.

3rd. On the Nebraskan glacial drift.

4th. On the Kansan glacial drift. This, with its modification of loess, is the present landscape.

The character and relation of these deposits and the sequence of events will now be presented in order.

\section{STRATIGRAPHY}

\section{NOMENCLATURE}

The various limestones at Winterset have not as yet been directly connected through intermediate beds in Iowa with the formations of southwestern. Iowa because of the thick deposits of drift that conceal all underlying deposits except in a few local $=$ 
ities at considerable distance from each other. Fortunately, however, the formations in Madison, Decatur and Clarke counties have been connected with those at Bethany Falls, Missouri, and thus with the series of outcrops along Missouri river to Kansas City, a series first worked out by Broadhead ${ }^{14}$ and recentiy reviewed by Hinds and Greene ${ }^{15}$. To the west end of this long series of outcrops G. L. Smith has connected outcrops in southwestern Iowa ${ }^{16}$, and continued the series northeast to Stennett a few miles southwest of Cass county, and to Briscoe south of Cumberland.

Not only is the work along Missouri river in Missouri essential to work in southwestern. Iowa, but also the work in Nebraska and in Kansas, for in those states the same formations appear that are found in southwestern Iowa. The strata in these different areas must be correlated.

Because of work from different starting points different naimes have been proposed for various important sets of strata, and different groupings proposed. Charles R. Keyes in 1899, seeking to coördinate these different names, proposed a series of terms that were accepted with some modifications by G. L. Smith in his report of the "Carboniferous Section of Southwestern Iowa." Recently Hinds and Greene in reviewing the work of Broadhead and correlating strata in Missouri with those in Kansas, have presented their reasons for refusing to accept some of the names adopted by Keyes and by Smith and have given a clear, systematio arrangement of terms based not only on the Missouri section but also on the Kansas and Iowa sections. With the exception of the use of Drum liméstone instead of De Kalb limestone all the variations from previous nomenclature used in Iowa seem well grounded and acceptable. It is not the present intention to discuss the relative merits and priority of the different terms. This has been nicely done both by Keyes in his early papers, and by Hinds and Greene in their recent review of the terms in the light of the latest research. It is necessary, however, to compare the terms as used by Keyes and by Smith with those used by Hinds and Greene and by Condra and Bengtson.

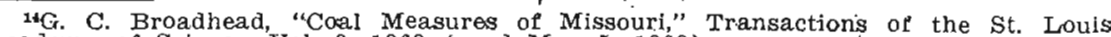
Academy of Science, $V o l .2,1868$ (read May 5, 1862).

${ }^{16}$ Henry Hinds and $F$. C. Greene, "The Stratigraphy of the Pennsylvanian Series in Missour1," Missouri Bureau of Geology and Mines, Vol. 13, Second Serles, 1915. ${ }^{10}$ George $L$. Smith, "Carboniferous Section of Southwestern Iowa," Iowa Geological Survey, Vol. XIX.
} 


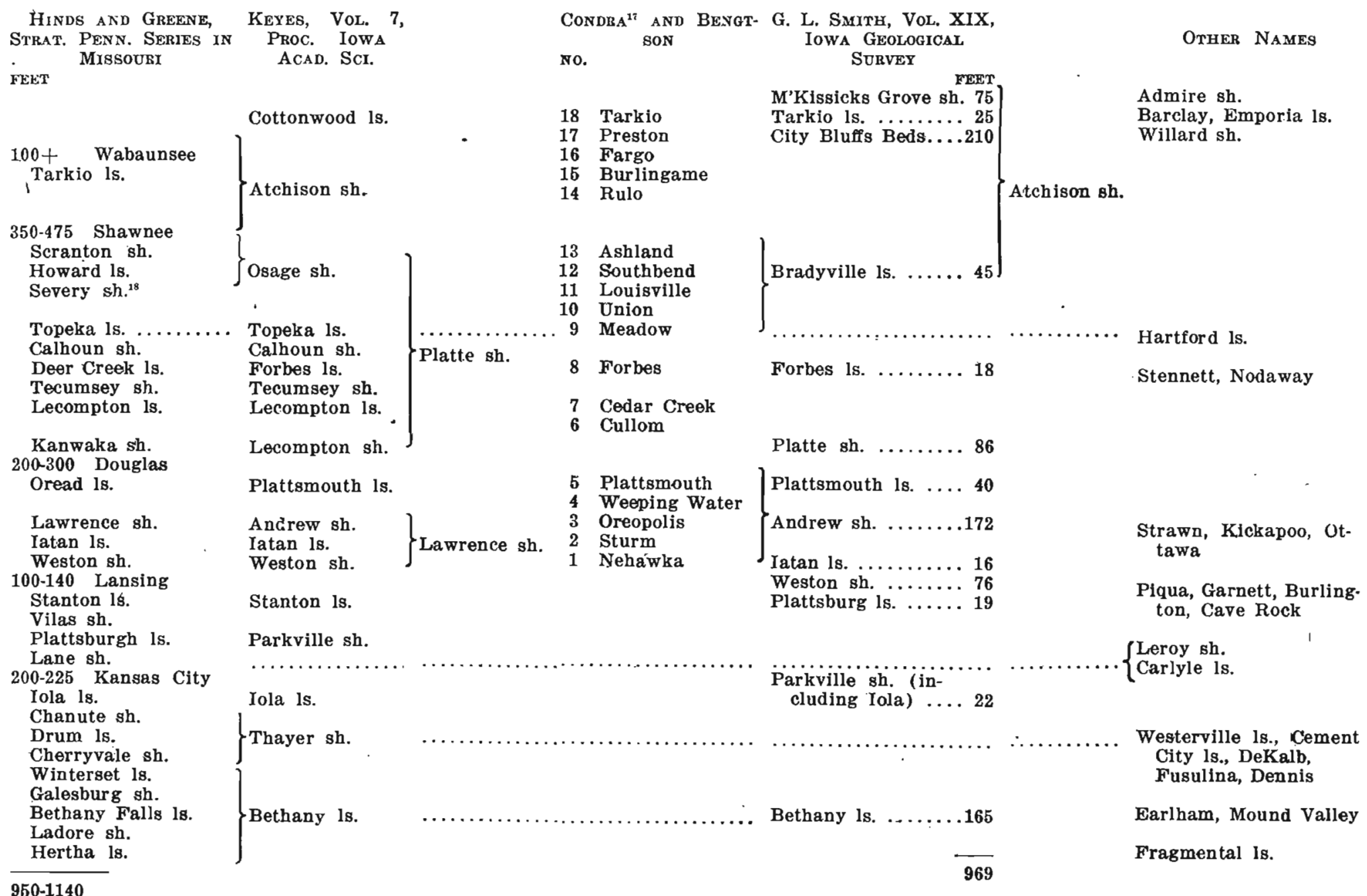


The part of the section along Missouri river that especially relates to the work in Cass county is the Shawnee formation, in which it will be seen that the Osage shales of Keyes are divided by Hinds and Greene into two divisions of shale with a limestone between. It will also be noted that G. L. Smith gives the name, Bradyville limestone, to the cap rock of the Nodaway coal, which coal in the Missouri river section is in the Severy shale, overlain by the Howard limestone. Since the name Howard limestone was proposed and defined in 1898 and the name Scranton shale in 1908 , both terms must be used in preference to Bradyville limestone and City Bluff beds, both of which terms were proposed in 1909, though they had been under consideration prior to that time. Forbes limestone as used by G. L. Smith seems in the general section ${ }^{19}$, but not in the records of core drilling; to include not only the thin beds of shale between the beds of limestone but also shale both above and below the limestones. Keyes recognizes the Forbes limestone as one of the subdivisions of the Platte shale. The other subdivisions are the same as those adopted by Hinds and Greene, excepting that Kanwaka shale supersedes Lecompton shale, the name Lecompton being retained for the limestone member.

In the table that follows Shawnee, Douglas, Lamising and Kansas City are mentioned as divisions of the Missouri stage, that the subdivisions may be listed as substages, but the beds listed as in general limestone contain partings of shale, and those listed as shale may include what is limestone.

SYNOPTICAL TABLE OF FORMATIONS

\begin{tabular}{|c|c|c|c|c|c|}
\hline GROTP & SYSTEM & SERIES & STAGE & SUBSTAGE & $\begin{array}{c}\text { CHARACTER OF } \\
\text { ROCKS }\end{array}$ \\
\hline \multirow[t]{2}{*}{ Cenozoic } & \multirow[t]{2}{*}{ Quaternary } & Recent & & & $\begin{array}{l}\text { A.luvium and } \\
\text { other surface } \\
\text { soil, clay and } \\
\text { sand. }\end{array}$ \\
\hline & & Pleistocene & Peorian & & Deposits of loess. \\
\hline
\end{tabular}

${ }^{17}$ Condra and Bengtson, "The Pennsylvania Formations of Southeastern Nebraska," Nebraska Academy of Science Publication, Vol, 9, No. 2.

The correlation here given of the subdivisions in Nebraska is by Dr. George E. Condra.

${ }_{20}$ Contains the Nodaway coal seam of Iowa, which is correlated as near the Quitman and Osage-Topeka coal seams.

${ }^{10}$ George L. Smith, "Carboniferous Section of Southwestern Iowa," Iawa Geological Survey, Vol. XIX, p. $655,1908$. 
SYNOPTICAL TABLE OF FORMATIONS-'(Continued)

\begin{tabular}{|c|c|c|c|c|c|c|}
\hline \multirow{5}{*}{ Cenozoic } & \multirow{4}{*}{ Quateruary } & \multirow{4}{*}{$\begin{array}{l}\text { Pleisto- } \\
\text { cene }\end{array}$} & \multicolumn{2}{|c|}{ Yarmouth } & & Kansan gumbotil. \\
\hline & & & \multicolumn{2}{|c|}{ Kansan } & & $\begin{array}{l}\text { Drift (bowlder } \\
\text { clay). }\end{array}$ \\
\hline & & & \multicolumn{2}{|c|}{ Aftonian } & & $\begin{array}{l}\text { Nebraskan gum- } \\
\text { botil. }\end{array}$ \\
\hline & & & \multicolumn{2}{|c|}{ Nebraskan } & & $\begin{array}{l}\text { Drift (bowlder } \\
\text { clay). }\end{array}$ \\
\hline & Tertiary & Pliocene & \multicolumn{2}{|c|}{ Ozarkian } & & $\begin{array}{l}\text { Bog and other de- } \\
\text { posits. }\end{array}$ \\
\hline Mesozol: & Cretaceous & $\begin{array}{l}\text { Upper } \\
\text { Creta- } \\
\text { ceous }\end{array}$ & \multicolumn{2}{|c|}{ Dakota } & & $\begin{array}{l}\text { Sandstone, a lit- } \\
\text { tle shale. }\end{array}$ \\
\hline \multirow{13}{*}{ 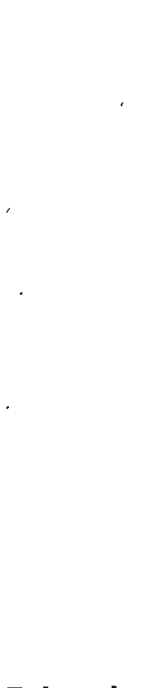 } & \multirow{26}{*}{$\begin{array}{l}\text { Carbon- } \\
\text { iferous }\end{array}$} & \multirow{26}{*}{$\begin{array}{l}\text { Pennsyl- } \\
\text { vanian }\end{array}$} & \multirow{9}{*}{\multicolumn{2}{|c|}{$\begin{array}{l}\text { Shawnee } \\
\text { Division }\end{array}$}} & Scranton & Shale. \\
\hline & & & & & Howard & Limestone. \\
\hline & & & & & Severy & $\begin{array}{l}\text { Shale; Nodaway } \\
\text { coal. }\end{array}$ \\
\hline & & & & & Topeka & Limestone. \\
\hline & & & & & Calhoun & Shale. \\
\hline & & & & & Deer Creek & Limestone. \\
\hline & & & & & Tecumsey & Shale. \\
\hline & & & & & Lecompton & Limestone. \\
\hline & & & & & Kanwaka & Shale. \\
\hline & & & \multirow{8}{*}{\multicolumn{2}{|c|}{\begin{tabular}{l|l}
$\underbrace{}_{2}$ & Lansing \\
Division &
\end{tabular}}} & Oread & Limestone. \\
\hline & & & & & Lawrence & Shale. \\
\hline & & & & & Iatan & Limestone. \\
\hline & & & & & Weston & Shale. \\
\hline \multirow[t]{13}{*}{ Paleozolc } & & & & & Stanton & Limestone. \\
\hline & & & & & Vilas & Shale. \\
\hline & & & & & Plattsburgh & Limestone. \\
\hline & & & & & Lane & Shale. \\
\hline & & & & & Iola & Limestone. \\
\hline & & & & & Chanute & Shale. \\
\hline & & & & & DeKalb & Limestone. \\
\hline & & & & Kansas & $\begin{array}{c}\text { Cherry- } \\
\text { vale }\end{array}$ & Shale. \\
\hline & & & & City & Winterset & Limestone. \\
\hline & & & & DIVIS10! & Galesburg & Shale. \\
\hline & & & & & $\begin{array}{l}\text { Bethany } \\
\text { Falls }\end{array}$ & Limestone. \\
\hline & & & & & Ladore & Shale. \\
\hline & & & & & Hertha & Limestone. \\
\hline
\end{tabular}




\section{GENERAL RELATIONS}

The formations in Cass county represent five series: the Pennsylvanian, the Upper Cretaceous, the Pliocene, the Pleistocene, and the Recent.

In the Pennsylvanian series only a portion of what is known as the Shawnee formation, or division, of the Missouri, is visible at the surface in Cass county, other divisions being concealed. The limestone was laid down when distinctly marine conditions prevailed; the shale, when shore conditions were nearer at hand. These conditions alternated back and forth a number of times. At one time the conditions were those of an extensive swamp in which the Nodaway eoal seam was laid down and then concealed by a subsidence in which first shale and then limestone were deposited, then shale again. Excepting in the southeast corner of the county all above the Deer Creek (Forbes, Stennett) limestone has been removed by erosion, and in the rest of the county many feet of the rocks below this limestone also have been removed in the long intervals that preceded the deposition of the Dakota sandstone.

During these great intervals of erosion many changes are recorded in.other parts of the country. It was in the first of these four periods, the Permian, that in the Appalachian region the strata there laid down were gradually crushed together and upheared into the Appalachian mountains, and the eastern half of the great interior of the continent was thrown into gentle folds and raised bodily above the ocean. Likewise in the southwest, as a continuation of the Appalachian folding, occurred a similar folding and uplift known as the Ouachita uplift. In the low ground of the southwest a wonderful Amphibian fauna left its impress. During the three remaining periods, the Triassic, Jurassic and Comanchian, or Lower Cretaceous, a remarkable reptilian fauna roamed over the land, swam in the waters, and even flew through the air. In the last of these three periods the sea advanced from the south as far as Kansas, and then, because of changes in level, retreated again far to the south.

It was during these long periods of erosion, while all of these changes were taking place, that the Pennsylvanian limestones 
and shales of Càss county were undergoing weathering and removal, the sediment was carried far to the southwest as valleys were eroded and a new landscape developed. Another change in level, accompanied by a downward warping of the northwestern part of the state, brought a new advance of the sea that crept farther to the east in the northern part than in the southern part of the state. This advancing Cretaceous sea spread beneath its waves the clays and sands of a submerging landscape, and then shore currents washed the sand into an extensive and thick bed that in Kansas, Nebraska and the Dakotas is the great water carrier supplying thousands of artesian wells, the Dakota Sandstone. In Cass county this sandistone is well exposed in some places, and extends beneath the glacial drift throughout a considerable portion of the county. If other Cretaceous strata, the Colorado, Montana and Laramie beds, were laid down within the confines of the county they have since been removed by erosion. Indeed, in the state as a whole remains of only the Dakota and of the Colorado deposits, the Niobrara, have been found.

During the time that what is now Cass county was beneath the border of this extensive sea there was a far different fauna and flora than had existed previous to that time. The leaves embedded in the I)akota sandstone are not like those found in Carboniferous strata, but are netted veined and somewhat modern in aspect, in contrast with the ferns and club mosses of the Carboniferous. Of animal fossils the great beds of Brachiopods of the Pennsylvanian are absent, and in their places are to be found beds of Pelecypods unlike those from the Pennsylvanian, though fossil shells have not been found in the deposits of Dakota age in Cass county, nor fossils of the remarkable reptiles of the types already mentioned that frequented the land and sea of Cretaceous time.

It was in the latter part of this the Cretaceous period that the Rocky Mountains were pushed up and the great interior sea was largely drained. During at least a part of this time, and probably all of it, what is now Cass county was again subject to erosion that continued during the periods of the Tertiary, the Eocene, Oligocene, Miocene and Pliocene, that followed, when large areas of the great West were sites of extensive lakes. Dur- 
ing this time a new landscape was here developed. River valleys were cut deep into the Dakota sandstone, and in places entirely through the sandstone into underlying limestone and shale of the Pennsylvanian strata. This erosion in a rugged country of sandstone hills continued till in Pleistocene time an advancing ice sheet, the Nebraskan, crept over Iowa. As this melted away the drift was at first deeply weathered, then somewhat uplifted and eroded ${ }^{20}$, and then the valleys were partly silted up in Aftonian time ere again an ice sheet, the Kansan, crept far to the south, and gradually melted away, this time leaving deposits that, while three different ice sheets, the Illinoian, the Iowan and the Wisconsin, invaded other parts of the state, were in Cass county constantly subjected to weathering under varying conditions of elevation, till now a new landscape meets our view, covered with the flora of the present, and inhabited by the recent fauna.

These four series of formations, the Pennsylvanian, Upper Cretaceous, Pleistocene and Recent, are thus separated by landscapes, each carved in the preceding deposits by the action of rivers, in coöperation with the other agencies such as are at work today in the formation of soil and of the hills and valleys of the present surface. The landscapes then formed deserve recognition along with the deposits themselves. Indeed, the relation of the various formations cannot be appreciated till the mind can picture the action in these long continued periods of erosion, and see these ancient hills and valleys in their relation to each other.

\section{PALEOZOIC GROUP. CARBONIFEROUS SYSTEM.}

\section{Pennsylvanian Series}

\section{MISSOURI STAGE}

The best section of Carboniferous strata to be found in the county is a mile west of Lewis, beginning with an exposure of limestone on Spring creek a few rods north of the bridge and extending up a small ravine to the west parallel to the road (west center of the northwest quarter of section 9, Cass township).

${ }^{20}$ The change in level was not very great. See discussion of Thickness of Aftonian Deposits, and Estimate of Aftonfan Retief. 
The Spring Creer Sechion a Mue West of Lewis.

\begin{tabular}{|c|c|c|c|}
\hline & & FEET & INCHES \\
\hline 13. & Soil, sandy $\ldots \ldots \ldots \ldots \ldots \ldots \ldots \ldots \ldots \ldots \ldots \ldots$ & 2 & \\
\hline 12. & Sandstone, fine-grained, thin bedded, yellowish & & \\
\hline & 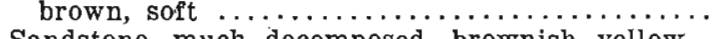 & 3 & \\
\hline 11. & Sandstone, much decomposed, brownish yellow.. & 5 & \\
\hline 0. & $\begin{array}{l}\text { Parting between beds of sandstone, like an un- } \\
\text { conformity, sloping irregularly northwest...... }\end{array}$ & & \\
\hline 9. & Sandstone, fine, yellowish, decomposed........ & 3 & 6 \\
\hline 8. & Nodules of hematite $\ldots \ldots \ldots \ldots \ldots \ldots \ldots \ldots$ & & $2-4$ \\
\hline 7. & Sand, white, unconsolidated $\ldots \ldots \ldots \ldots \ldots \ldots$ & 1 & \\
\hline 6. & Sandstone, imperfectly exposed $\ldots \ldots \ldots \ldots \ldots$ & 8 & \\
\hline 5. & Shale, imperfectly exposed $\ldots \ldots \ldots \ldots \ldots \ldots \ldots$ & 3 & \\
\hline 4. & $\begin{array}{l}\text { Shale, blue in upper portion, then dark reddish } \\
\text { brown, then yellowish and soft (yellow ochre), } \\
\text { then brownish red } \ldots \ldots \ldots \ldots \ldots \ldots \ldots \ldots \ldots \ldots\end{array}$ & 7 & 6 \\
\hline 3. & Limestone, gray, full of Fusulina............ & 5 & 6 \\
\hline 2. & Shale, gray $\ldots \ldots \ldots \ldots \ldots \ldots \ldots \ldots \ldots \ldots \ldots$ & 2 & \\
\hline 1. & $\begin{array}{l}\text { Limestone in thin layers, gray; Crinoid stems, } \\
P . \text { longispinus, } P \text {. nebrascensis, C. verneuilianus, } \\
\text { S. subtiitia, } S p \text {. cameratus and Bryozoa...... }\end{array}$ & 4 & 10 \\
\hline & & & \\
\hline & Creek & 45 & 8 \\
\hline
\end{tabular}

In this section, the lowest part (numbers 1-5) is distinctly Carboniferous (Missouri) and the upper part (numbers 6-12) is distinctly Dakota sandstone. The dividing plane is judged to lie in number 5, beneath which the shale is like water soaked Carboniferous shale, while above it sand is the chief constituent. Number 3 of this section is the stratum used in comparing elevations of different outcrops: number 7 at Stennett, numbers 8 to 9 at Fox quarry, the outerops a mile and a half south of Lewis, and those on Turkey creek three and a half miles northeast of the Spring creek outcrop.

A mile west of Spring creek, Indian creek exposes limestone and shale (southwest quarter of the southwest quarter of section 5). Here two inches of fossiliferous limestone lies over two feet of blue shale. These are parts of numbers 2 and 3 of the Spring creek section. Still farther west, near the southwest corner of section 7, but in the next county, a well in the upland is said to have reached limestone at a depth of two hundred feet with no evidence of sandstone above it.

Near the mill at Lewis, a mile east of the Spring creek section, the water falls about eight feet over a dam that is said to rest on limestone. Such limestone as is visible corresponds to number 1 of the Spring creek section. At the old quarries below the dam 
(northeast quarter of the northeasit quarter of section 9, Cass township) about six feet of this same limestone and overlying gray shale appear, above which are two feet of a yellow shale, then three feet of a washed deposit containing brown sand. The top of the limestone, corresponding to number 3 of the Spring creek section, is here seventeen feet above the water in the river and perhaps three feet above the general level of the bottom land. At present all beneath the limestone is concealed and there is no well record revealing the stratum.

The section at Lewis as it was exposed in 1870 is given by White ${ }^{21}$ :

\section{White's Section at Lewis (1870).}

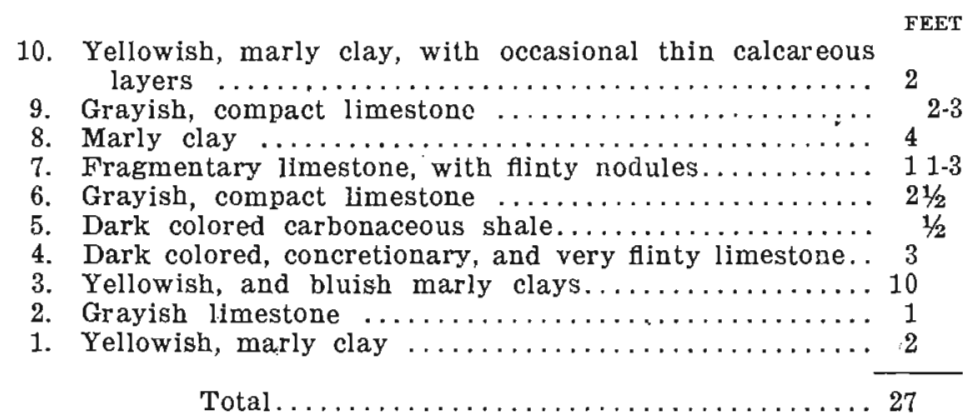

A mile southwest of Lewis a few beds of limestone and shale appear in the hillside on the south side of the river (southwest quarter of the northwest quarter of section 15).

It is said that there used to be a ford two miles north of Lewis not far from the present bridge in that locality, and that near this ford limestone was to be seen in the bed of the river. At the present time the limestone is not visible, at least when there is a considerable volume of water flowing in the river.

Near the southwest corner of section 31, Grove township, limestone is said to have been taken from the bed of the creek, but the strata are now concealed. In the south half of the northeast quarter of section 1, Cass township, three feet of limestone exposed on the side of a ravine is a mass of Fusutinas, with a light yellowish brown sandstone above. Aeross the road to the east an upper six inches of this limestone, here thin bedded, is crossed p. 374 . 
by the creek. Here may be seen Crinoid stems, Polyzoa, Chonetes verneuitianus, and many fragments not identifiable.

Close to the south county line are the Fox quarries, in which little work has been done in recent years. The following section. was obtained east of the road (northeast quarter of the northeast quarter of section 31, Edna township).

\section{Section at FoX QUARry}

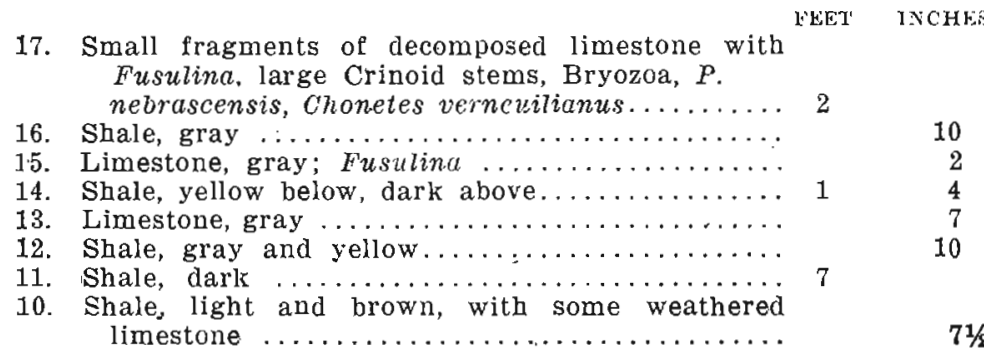

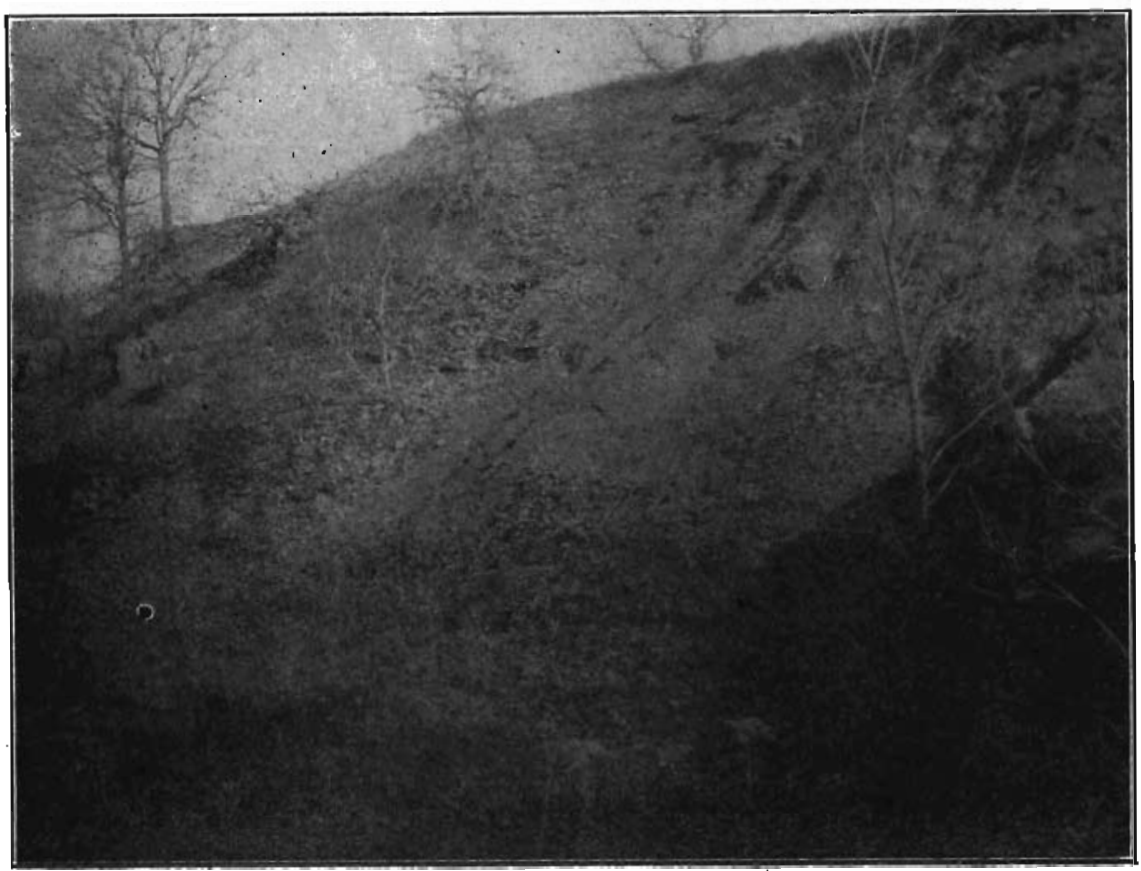

FIG. 27.-Fox quarry, east of the road. (Northeast quarter of the northeast quarter of section 31, Edna townshlp, Cass county.) 
9. Limestone, 'light gray; numerous Crinoid stems.. 2

8. Limestone, light gray, dense stratum .......... 1

7. Not exposed ....................... 2

6. Limestone, light gray, dense stratum......... 2

5. Limestone, light gray, in several thin layers; many Fusulina; dip $1^{\circ} 45^{\prime \prime} \mathrm{S} 10^{\circ} \mathrm{W} . . . . . .$.

4. Limestone, light gray; Crinoid stems, Bryozoa, Derbya crassa, Stroparollus, and many shell fragments $\ldots \ldots \ldots \ldots \ldots \ldots \ldots \ldots \ldots \ldots \ldots \ldots \ldots \ldots$

3. Limestone in two layers; ccrals: shaly parting

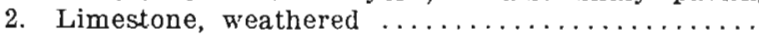

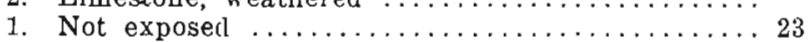

River bed, low water

In the above section numbers 4 to 6 correspond to number 1 of the Spring creek section, while numbers 8 to 9 correspond to number 3 of the Spring creek section. The crinoid stems in number 9 are more noticeable than in number 3 at Spring creek.

Across the road to the west, in section 36 of Noble township, are the same beds above described except the topmost one, which is absent; but the beds are even less exposed to observation. They were described by Lonsdale in his report on Montgomery county ${ }^{22}$, and also by G. L. Smith ${ }^{23}$ in his paper on Southwestern Iowa.

Half a mile up the river from Fox quarries ten feet of limestone bearing Fusulinas are to be found above a crinoidal limestone two to three feet thick and corresponding to numbers 6 to 9 of the Fox quarry section. The ten feet next below are not exposed. In the bed of the river is a foot of thin bedded limestone.

On Rose branch just south of the county line (opposite the southwest quarter of the southeast quarter of section 32, Noble township) are traces of an old quarry. No strata in place are now visible, but fragments at hand are of the Fusulina limestone, like that at Fox quarries not far away.

Three miles east of the Fox quarries, but in the next county south, Adams, is a coal shaft at the Briscoe mine (opposite the southeast quarter of the southwest quarter of section 34, Edna township), on which Mr. Charles Porter gives the following data:

\footnotetext{
"E. H. Lonsdale. "Geology of Montgomery County," Iowa Geological Survey, Vol. IV. pp. 393-394, 1894.

Smith, "Carboniferous Section of Southwestern Iowa," Iowa Geological Survey, Vol. XIX, pp. 627-628
} 
The dip of the coal as measured by the writer is $2^{\circ} 48^{\prime}$ to the south.

The Chapman mine near the above mine is described by C. $R$. Keyes ${ }^{24}$ and Henry Hinds ${ }^{25}$.

The section at Stennett, to which frequent reference must be made under Correlation, is described as follows by G. L. Smith ${ }^{20}$ :

The Section at StennetT.

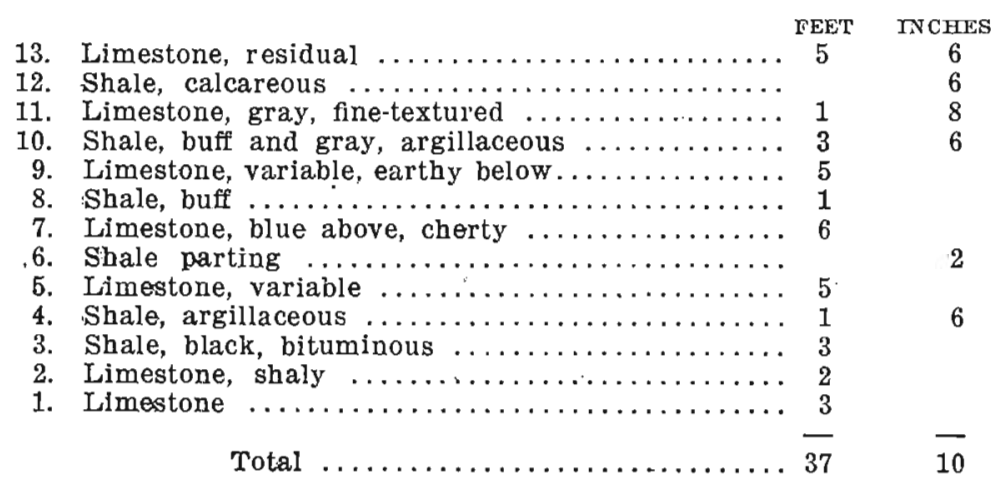

Dr. Smith states that in the above section at Stennett, "numbers 1-4 belong to the Platte shales, numbers 5-9 are the Forbes limestones (Deer creek), and that above No. 9 is the lower part of the Braddyville (Howard) limestones."

Distribution.-In the western part of the county the Missouri formations with their limestone and shale lie next beneath the glacial drift and alluvium along the valley of Nishnabotna river from two and a half miles northwest of Griswold to about five miles north of Lewis, along the valley of Indian creek as far

\footnotetext{
${ }^{24}$ C. R. Keyes, "Coal Deposits of Iowa" Iowa Geological Survey, Vol. II, p. 441. p. 392

392.

${ }^{37 \mathrm{G} .}$ L. Smith, "Carboniferous Section of Southwestern Iowa," Iowa Geological Survey, Vol. XIX, p. 636.
} 
north as the southern boundary of Washington township, and along the valley of Turkey creek to the northwest corner of Beargrove township. From well records it appears to ba next beneath the drift for a part, if not all the way, north from Lewis through section 11 of Washington township, 25 of Brighton township, and 17 and 8 of Pymosa township. The area along Turkey creek is extended south by a well record to the town of Marker (section 3 of Beargrove township). In a northeasterly direction are isolated areas in section 33 of Franklin township and 26 of Benton township, and still farther to the east in sections 10 and 15 of Lincoln township. In the southern part of the county it lies immediately beneath the glacial drift along Three Mile creek as far north as section 23 of Noble township, is beneath a thin deposit of Dakota sandstone in section 18 of Edna township, and beneath drift again in section 20 of Union.township. It outcrops in the south bank of section 36 of Noble town-

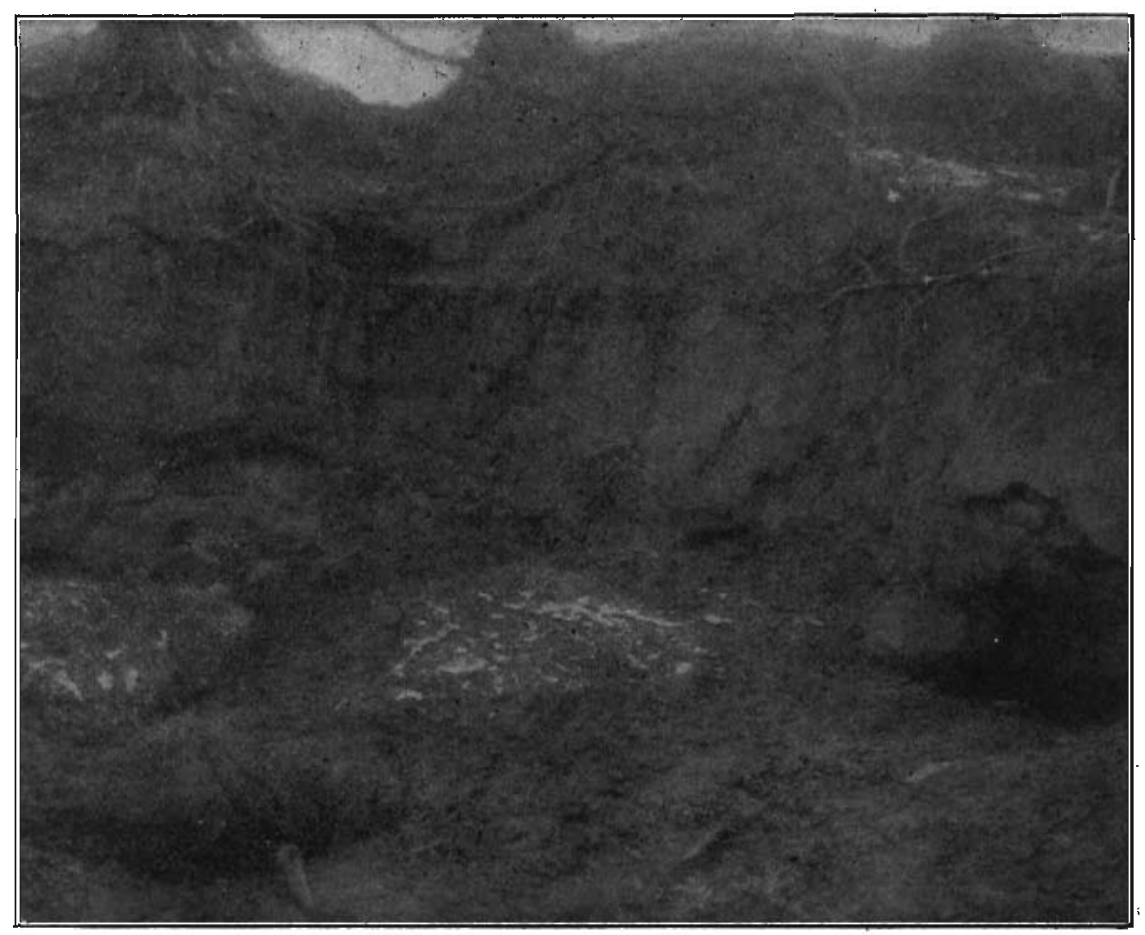

FIG. 28.-Dakota sandstone at Spring Creek. (West center of the northwest quarter of section 9, Cass township, Cass county.) Numbers 9 to 12 lorm 
ship, and 31, 30, 29 and 28 of Edna township, and has been penetrated by digging along a narrow strip south of the creek in sections 34 and 35 . To the northeast of these locations it is found beneath the drift in section 20 of Victoria township, in sections 30, 32 and 27 near Massena, and beneath a thin deposit of Dakota sandstone in sections 5 and 6 southwest of Massena.

Presumably the above named records mark the distribution of higher portions left after erosion in the great intervals of time between the close of the Carboniferous period and the beginning of the Cretaceous. Along the streams the Carboniferous strata are exposed only in places, as in the neighborhood of Lewis and Iranistan and southwest of Reno. Generally the glacial drift extends below the level of the streams. Northwest of Griswold, in Pottawattamie county, the Dakota sandstone is beneath the level of the river; and throughout the upland generally wells equal in depth to some which reach Carboniferous strata, penetrate Dakota sandstone, and do not reach Carboniferous at all.

It is also noticeable that all but one of the wells that are reported to reach the Carboniferous strike a resistant limestone, not shale; and that near Lewis and Iranistan, and along Turkey and Three Mile creeks, a resistant limestone is at or near the uppermost Carboniferous exposed, though southwest of Reno and at the mine at Briscoe, southeast of Reno, shale lies above limestone.

These exposures of the Carboniferous and the wells that reach it are largely in the southwest half of the county.

Correlation.-In testing the above correlation based on general texture, sequence and fossil content the following data have been secured from railroad levels and barometric measurements :

\begin{tabular}{|c|c|c|c|c|}
\hline & $\begin{array}{c}\text { Altitud } \\
\text { above se } \\
\text { level }\end{array}$ & $\begin{array}{l}\text { Diffe } \\
\text { en }\end{array}$ & $\begin{array}{l}\text { Dis- } \\
\text { ce tance }\end{array}$ & Dip. \\
\hline & FEET & FEET & MILES & \\
\hline Top of No. 3 , Spring creek section.... & 1109 & 0 & 0 & $3^{\circ} 45^{\prime} \quad N^{\circ} 5^{\circ}$ \\
\hline Top of No. 3 at Lewis, below dam.... & 1110 & 1 & $1 / 2$ & $45^{\prime}$ N. $5^{\circ}$ \\
\hline $\begin{array}{c}\text { Top of Fusulina limestone, Turkey } \\
\text { creek } \ldots \ldots \ldots \ldots \ldots \ldots \ldots\end{array}$ & 1123 & 14 & 4 & Horizontal \\
\hline Top of No. 7, Stennett............. & 1076 & -23 & $171 / 2$ & $3^{\circ} \mathrm{E}^{.7}$ \\
\hline Top of Nos. 7 to 9 , Fox quarries..... & 1135 & 26 & $131 / 2$ & $1^{\circ} 45^{\prime}$ S. $10^{\circ} \mathrm{W}$. \\
\hline
\end{tabular}


In this marked difference in dip there is a general plan. At Stennett and Fox quarries the dip in the limestone is toward a fault plane, the facts concerning which will be discussed later. At Lewis, northwest from this fault plane, the dip is in the opposite direction from that at Fox quarries; and at the most distant place, at Turkey creek, the beds are almost horizontal.

The second most noticeable fact is the actual difference in level between number 7 at Stennett and numbers 8 and 9 at Fox quarries, at which places it has previously been thought the same formations outcropped. ${ }^{28}$ Half way between these two levels are the limestones at Lewis and Spring creek; and three-quarters of the way up between them are the limestones at Turkey creek; but the differences in level between them all are so slight that they might be accounted for by slight local differences in dip.

The third most noticeable fact is that from Stennett to Stuart the strata go down the geological sequence; for the Des Moines formation is at the surface along ravines just north of Stuart, and was reached by a mine shaft six miles south of Adair. At present there are no data whatever of the presence of a fault extending northwest-southeast across this region ${ }^{29}$. The difference from Stuart to Stennett can be accounted for most satisfactorily by a general dip to the southwest. This, however, is not true with reference to a northeast-southwest fault at right angles to the above named northwest-southeast direction, as will be discussed at the close of the description of the stratified rocks.

In the preceding discussion the Fusulina beds at Spring creek, at Lewis, at Turkey creek and at Fox quarries are described as one and the same bed. The slight differences are accepted as possible in a region of varying dip, especially when it is noted that Spring creek, Lewis and Turkey creek are from seven and a half to eight and a half miles to the northwest of the line of reference (from Stennett to the Eureka shaft) and Fox quarries are five and a half miles to the southeast of that line. When, however, comparison is made between the dip and the level of

\footnotetext{
${ }^{25} \mathrm{G}$. L. Smith, "Carboniferous Section of Southwestern Iowa," Iowa Geological Survey, Vol. XIX. 1909, pages 627-628 and 636

couth south of Clark county. See also the report on the geology of Clarke county, by the present writer, and comments on the geology of Adair accompanying the report on Adair county,
} 
numbers 8 and 9 at Fox quarries and the dip and level of number 7 at Stennett, twelve and a fourth miles southwest of Fox quarries, the difference is not so easily aocounted for. Comparing the sequence at Fox quarries with the sequence at Stennett, it is noted that numbers 2 to 9 at Fox quarries present seven feet and eleven inches of limestone, with not over two feet of intercalated shale, and that shale is in one bed concealed; while at Stennett there are twenty-one feet of limestone and seven and a half feet of intercalated shale, divided between four distinct beds. Furthermore, numbers 3 to 4 at Fox quarries have an abundance of fossils in the lowest part with a Fusulina bed nearly two feet thick immediately above, not to mention the Fusulina bed at the top of the quarry; while near the base of the limestone at Stennett there is no such fossil horizon, nor is there such a distinct Fusulina limestone present. It therefore appears to the writer that the beds at Stennett are not ${ }^{30}$ identical with those at Fox quarries nor with those at Spring creek, Lewis and Turkey creek.

How, then, can these isolated beds of southwestern Cass county be located in the Missouri section?

Data published by the survey make it possible to determine the position of the base of the Missouri limestone to the northeast at the old Eureka shaft ${ }^{31}$ just east of the county line southeast of Anita. The base of the Missouri limestone is here close to 1,198 feet above sea level.

It is assumed that the limestone outcropping at Stennett, in the opposite direction, where it has been carefully studied, has been correctly identified by G. L. Smith ${ }^{32}$. If the Clarinda.well record from the Deer creek (Forbes) limestone down is drawn beneath the section at Stennett, the base of the Missouri limestone at Stennett is located at 471 feet above sea level. This gives a difference in level of 727 feet in thirty-four and a half miles, which is twenty-one feet per mile, which corresponds to an average dip in this direction of fifty-four and six-tenths minutes.

\footnotetext{
${ }^{30}$ Compare p. 627, Carboniferous Section of Southwestern Iowa, Iowa Geological Survey, Vol. Xix.

siNortheast quarter of the northwest quarter of section 4, Eureka townshlp, Adair county. See C. R. Keyes, "Coal Deposits of Iowa," Iowa Geological Survey, Vol., II, p. 442 , 1894 .

Town "Carboniferous Section of Southwestern Iowa," rowa Geological Survey, Vol. XIX, and further papers by Smith in volumes XXII and XXIII of the Proceedings of the Iowa Academy of Science. For the record of the Clarinda well see p. 618. of Vol. XIX, Iowa Geological Survey.
} 
Iowa Geological Survey

Plate I

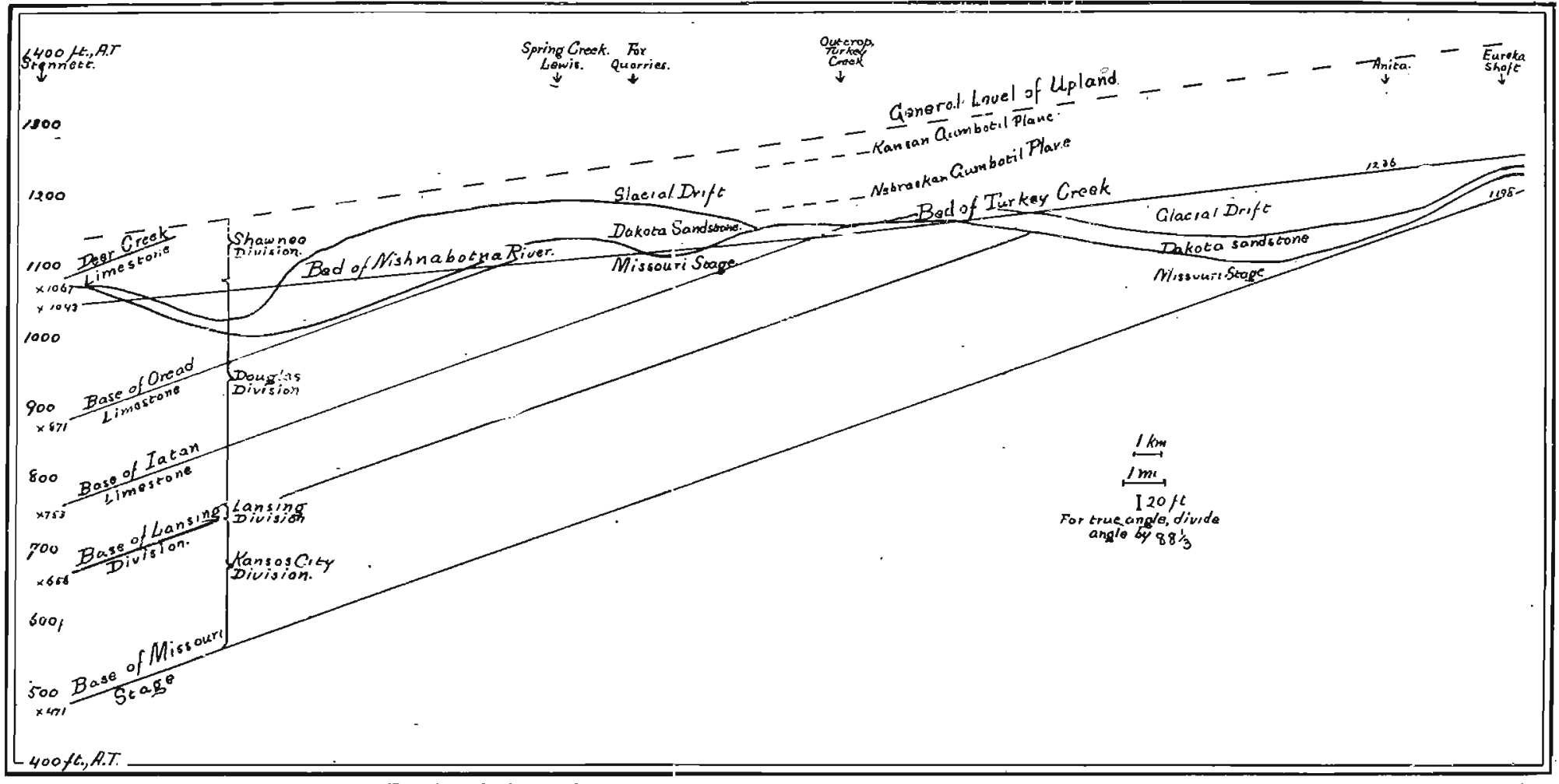

Diagram of structure from Eureka shaft southwest across Cass county to Stennett along the west ofde of the fault plane. "The 618 ), except that the Oread limestone (No. 78) is, for the reason given in the text, drawn seventy feet below the position stated in the drill record. 
The various beds below the Deer creek at Stennett should lie consecutively next beneath the Dakota sandstone or the drift between Stennett and Eureka shaft, with minor variations due to changes in dip and to possible thinning of the shaly members benleath the Oread limestone, as stated by Hinds and Greene ${ }^{38}$. An exact plotting brings a part of No. 71, a shale at a depth of 315 to 346 feet in the Clarinda section, to the surface at Fox quarry. A variation downward of about seventy feet, due to dip, to a thinning of the shale, or both combined, would bring No. 78 of the Oread (Plattsmouth) limestone to the level of the Fusulina bed at Fox quarry. A variation upward would bring the Iatan limestone to this level. The description of the Iatan limestone given by Hinds and Greene does not fit, that limestone being particularly deficient in Fusulina beds, while such beds are a marked characteristic of the Oread (Plattsmouth) limestone. In the Clarinda well record such a limestone bed is particularly mentioned (No. 78) in the base of the limestone. In Missouri such beds are mentioned as present, but they are especially characteristic of the upper portion of the formation. At Fox quarries Fusulinas are exceedingly abundant in a thin stratum of weathered limestone at the top of the excavation, and the succession of limestone and shale and the character of all the beds fits nicely the general description given of the Oread beds of Missouri. It therefore appears that the limestone in southwestern Cass county is the Oread limestone.

Since the Oread limestone outcrops in the southwestern part of Cass county the Iatan limestone must come to the plane of unconformity beneath the Dakota sandstone near Cumberland; and the Plattsburg limestone should come to this plane of unconformity about half way between Cumberland and the eastern border of Lincoln township. Consulting the distribution of the Missouri as indicated by well records it will be noted that the Missouri formation (probably the highest portions of it) was encountered immediately beneath the drift in a line from section 28 to section 3 south of Atlantic, (see accompanying map of the geological formations of the county) in section 17 northwest of Cumberland, and in two areas north of Massena. It will also

\footnotetext{
wHinds and Greene, "The Stratigraphy of the Pennsylvanlan in Missouri," p.
} 183, 1915. They state that the shale is 145 feet thinner in Iowa than in Missour. 
be noted that another area, for the Stanton, or Platısburg, limestone, appears in Lineoln township and northeast of Wiota. Apparently the intervening concealed portions stretching northwest to southeast between these areas mark the locations of the Lawrence (Andrew) shales, Weston shales and Lane (Parkville) shales. The beds of the Kansas City formation are known to lie beneath the Dakota sandstone in Eureka township of Adair county, close to the southeast corner of Grant township, Cass county; hence they lie next beneath the Dakota sandstone and the drift throughout nearly all, if not all of Grant township, the northeast half of Benton township, and the northeast third of Lincoln township.

Throughout the larger portion of Cass county, as well as of adjacent regions to the west, north and east of Cass county, these formations are concealed both by thick deposits of drift, and by deposits of Dakota sandstone. The distribution of outcrops and well records, as illustrated on the map, indicates that the northeastern boundary of each formation curves toward the west, so that in the southeastern parts the general direction is northwest-southeast, while in the northwestern parts of the county the general direction is several degrees more to the west, ten degrees in the north center of the county and nineteen degrees in the southwest portion of the county.

The above discussion applies to that portion of Cass county northwest of a line drawn northeast from where the road south from Cumberland to Briscoe crosses the county line, to the northeast corner of Victoria township. Southeast of this line the Scranton shale and Howard limestone, above the Severy shales, including the Nodaway coal, of the Shawnee division are beneath the Dakota sandstone and the drift.

\section{MESOZOIC GROUP. CRETACEOUS SYSTEM.}

\section{Upper Cretaceous Series}

DAKOTA STAGE

In the Spring creek exposure already described (west center of the northwest quarter of section 9, Cass township) a part of number 5 and all above that number are referred to the Dakota sandstone. In this particular locality there is considerable 
sand with the shale, so that the strata are described as sandstones, which in position correspond to what in other places are distinctly shales. The heavy beds of sandistone, numbers 9 to 12, form the cliff at the bottom of which are springs. In number 10 there is in the sandstone a parting sloping irregularly northwest. Crossbedding due to current action is a common feature in the sandstone.

At Crystal Lake (southeast quarter of the southwest quarter of section 15, Cass township), a mile south of Lewis, there is a delightful shady recess beneath a cliff of sandstone which rises to a height of twenty-four feet, above which is a bowlder clay sloping back to the highest ground of the upland. Water from the base of the sandstone, and just above the underlying shale, is piped into an artificial pool near at hand. The top of the shale and the base of the sandstone at the pool are thiry-eight

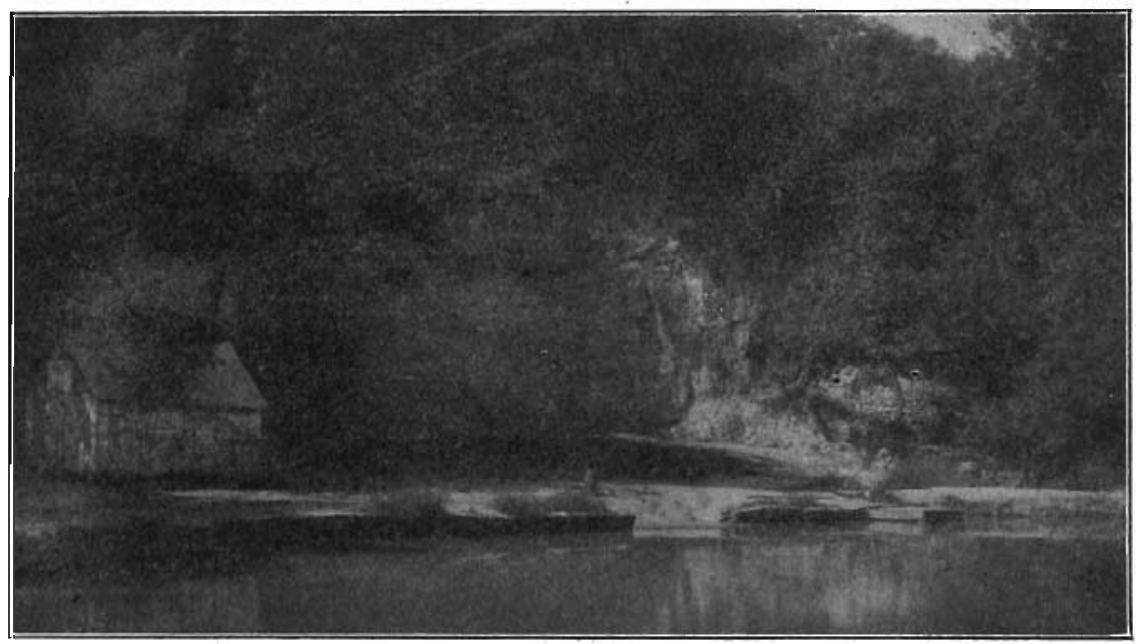

Fig. 29.-Crystal Lake is a delightful spot. The bluff of Dakota, sandstone is on the south side of the pool.

feet above the bed of the river. Near the top of the sandstone - there is a curved plane of separation between a finer stratified sand above and a coarser sand beneath and on one side of the finer sand, seemingly marking a plane of contemporaneous erosion. This is at about the level of the shale half a mile to the southeast. 
6. Bowlder clay

$\ldots \ldots \ldots \ldots \ldots \ldots \ldots \ldots \ldots \ldots \ldots$

5. Sandstone, irregularly bedded, part stained yellow 10

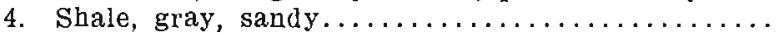

3. Sandstone, white, fine above; light buff and soft below, cross bedded, with bedding planes dipping

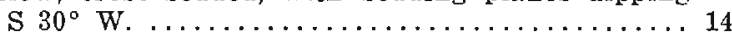

2. Apparently shale, inperfectly exposed........ 3

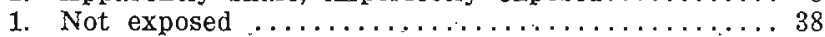

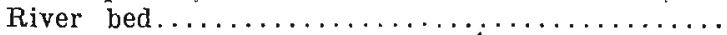

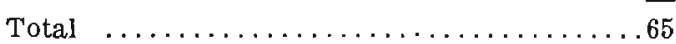

The strata in the bluff $\operatorname{dip} 6^{\circ}$ in a direction S. $30^{\circ}$ W. There are two sets of joints, one vertical, that extends N. $8^{\circ} \mathrm{W}$. The other, dipping $83^{\circ} \mathrm{N}$., extends N. $75^{\circ} \mathrm{E}$.

South from Crystal Lake the sandstone and a white shale appear by the roadside (southwest quarter of the southwest quarter of section 15). Farther south and east it appears in a small exposure by the roadside (northeast quarter of the southeast quarter of section 22). A mile to the northeast (northeast corner of section 23) about five feet of a dark brown sandstone appears in the side of a trench. By the roadside half a mile south of Lewis the dark brownish sandstone has been quarried (east half of the southeast quarter of section 15).

West of Griswold, and west of the county line, there is for half a mile along the west side of Nishnabotna river a bluff of Dakota sandstone twenty-five feet high the base of which is beneath the level of the water in the river. At the north end of this prcturesque region and just over the county line west of section 31, Cass township, is an excellent exposure of about eight feet of shale beneath the sandstone. In the upper portion of this shale iron concretions are interstratified; at the base of the exposure fragments of lignite are to be found in the shale. The sandstone above the shale is of variable thickness, and in one place slopes down northward over the shale. At a house near by the well is said to reach sandstone at a lower level than the sandstone by the river. Perhaps this shale is a lenticle in the sandstone. The lignite gives evidence that it is Cretaceous; at this place it must be close to the top of the Carboniferous. A similar shale is found in section 16 of Pleasant township. 


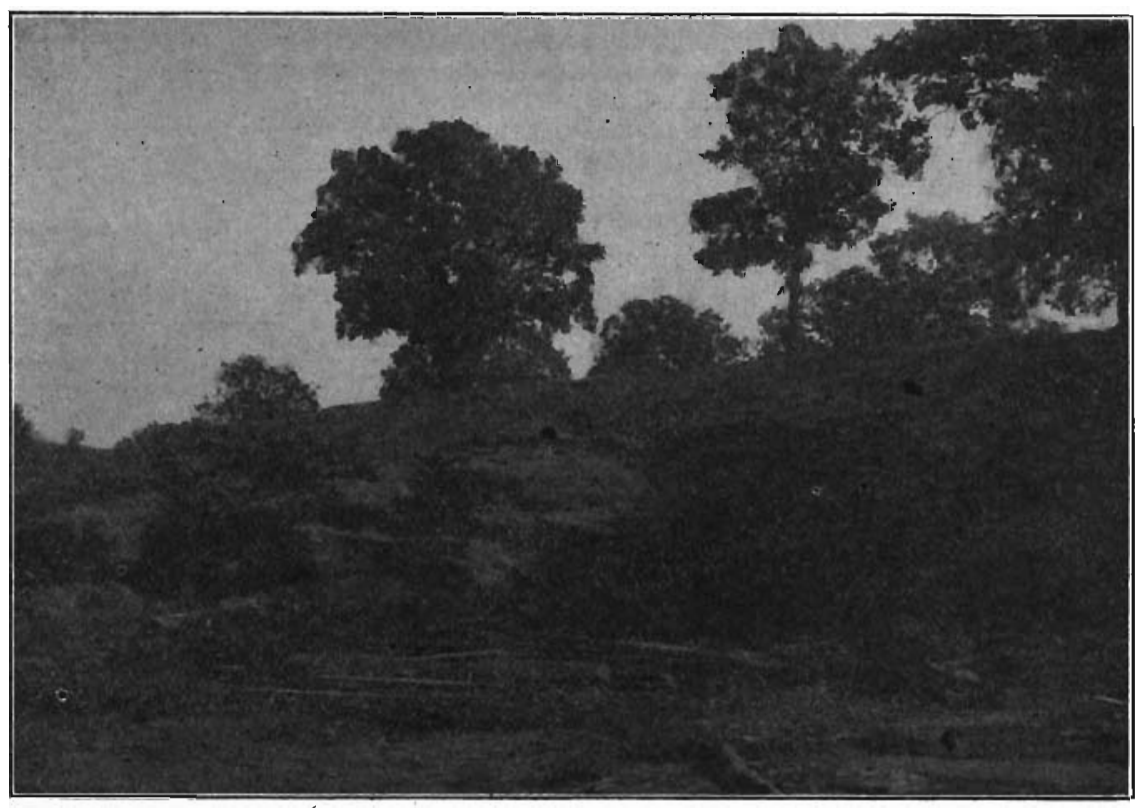

Fig. 30.- On the east side of the road a mile south of Lewis a dark brownish sandstone has been quarried.

Still another exposure of this Dakota sandstone, giving a touch of ruggedness to the general type of the topography, is located near Galion in section 35 of Beargrove township, extending for an eighth of a mile along the south side of the creek through the section. At one place there is a small amphitheater about fifty feet across, where the sandstone rises perpendicularly to a height of thirty feet. 'The base of the sandstone is' covered with mud from the adjacent creek; the lower portion that can be seen is white, and the upper portion is red.

Four miles to the south (northwest quarter of the southwest quarter of section 17, Noble township) nine feet of sof $t$ white sandstone, in a knoll twenty feet above the bed of the ravine to the west, is quarried for sand.

Three miles farther southwest (south one-half of the southwest quarter of section 31 , Noble township) the sandstone is visible close to the county line, where it evidently forms a lobe of a sandstone hill under the drift, and is exposed along small 
ravines cut in the southwest corner of the section. Here are small sandstone cliffs rising twelve feet above the bed of the ravine.

Four feet of sandstone exposed in two other places (southwest quarter of the northeast quarter and northeast quarter of the northwest (quarter of section 32, Pleasant township) mark the site of another hill of Dakota sandstone beneath the drift. In section 16 of the same township is a shale, like that already described as included in sandstone northwest of Griswold, marking the site of still another hill.

Along West Nodaway river the Dakota sandstone is visible south of Reno. In a small ravine in section 32 (northeast quarter of the northwest quarter) about six feet of brown sandstone appear in the ravine side a few rods south of the road. Near the road the fine, white, soft sandstone beneath the brown has been dug into for sand. In the southeastern quarter of section 30 there is evidence of it above the limestone. In section 17 (southwest quarter of the southwest quarter) there is the following section:

Expostue in Section 17, EDNi Townsimp.

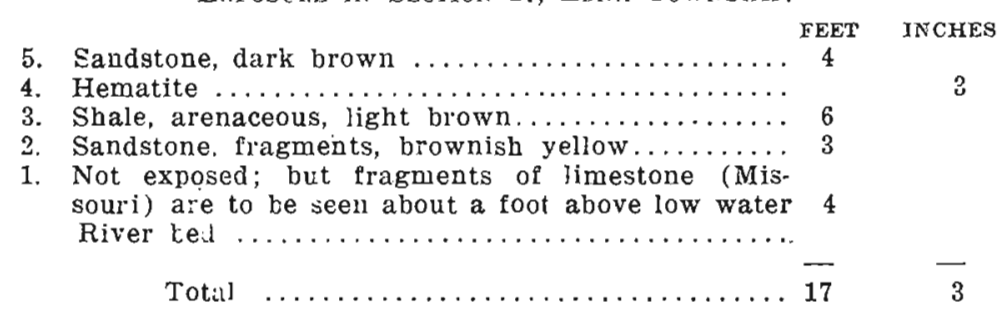

In the northern part of section 20 of the same township a brownish ycllow stratified sand is exposed in the river bank for a distance of perhaps fifty feet up to a height of twenty feet. This is unciuestionably a weathered Dakota sandstone. Likewise farther up the stream water comes from Dakota sandstone along trenches of ravines in sections $10,12,14$ and 15 . The sandstone is said to have becn exposed in section 10, but it is now concealed so that its character is not known. So, too, along this river there are numerous springs in section 6 of Victoria township and farther up nearly to Massena (seotions 32 and 33 of Massena township) though conditions here indicate that a part of the water may come from Aftonian deposits. 
Away from these exposures the records of wells that pass through the drift reveal the presence of sandstone in all directions excepting where the Missouri formation is exposed to view along river valleys as previously described. As the sandstone is an important water carrier wells do not often penetrate far into it, generally but a few feet. Of thirty-nine revealing the presence of Dakota sandstone and also passing through it, or so far into it as to make it possible the entire deposit may have been penetrated, the average thickness is forty feet, the greatest thicknesses being 120 and 147 feet. Even if the two excessive records be eliminated as possibly not correct, the remainder give a very uneven thickness ranging from three and one-half to ninety feet.

It will be noted that exposures of Dakota sandstone do not parallel the exposures of Missouri limestone and shale. The sandstone is exposed along Nishnabotna river even where the limestone is beneath the river bed. Between: the valley of this river and that of the West Nodaway it appears exposed by erosion of the drift in eight places. In the county as a whole 108 wells at or near the level of the upland give the surface of the Dakota sandstone as varying from 30 to 250 feet, with the average depth from the surface of the upland down to the surface of this sandstone as 140.8 feet. Assuming these figures to be approximately correct the maximum relief carved in the Dakota sandstone is 220 feet.

The steepness of the slopes carved in the sandstone has been mentioned in the description of outcrops. It is evident also in the well records. In Brighton township the surface of the sandstone is 220 feet below the level of the upland in the northeast part of the township and 100 feet in the southwestern portion of it. At one point eight feet of brownish sand exposed along Indian creek (northwest quarter of the northwest quarter of section 32) is thought to be from the Dakota sandstone. In Pymosa township it is at a depth of 200 feet at the county line and at a depth of 176 feet two miles south. In Grant township it is 220 feet down on the east side of the creek and 87 on the west side. In Washington township it is 31 feet beneath the upland in section 15 and 212 feet a mile and a half to the north- 
east. In section 3 of Franklin township it is 99 feet below the upland. Half a mile south it is 125 feet, and a mile east of the latter place it is 176 feet. At Lewis it is 70 feet below a low upland, and two miles east it is 170 feet. In section 10 of Beargrove township it is 52 feet beneath the upland at one point and 132 feet a few rods away. In section 10 of Union township a record on the west side of the section gives 60 feet; one on the east side gives 174 and another 200 feet. In section 6 of Massena township one record gives 175 feet and another 254 feet. In section 2 of Pleasant township it is 62 feet below the upland; a mile southward it is 144 feet. In section 8 of Euna township it is 40 feet; half a mile to the south it is 150 feet. In section 13 it is 106 feet, and a mile and a half east in Victoria township it is 200 feet below the upland.

Not far from Lewis the depth to the sandstone is generally less than 100 feet, and exposures of it are most numerous in this part of the county. In the eastern part of the county exposures would certainly be as common as they now are near Lewis if valleys there were as large and deep as near Lewis.

Ridges of Dakota sandstone are recognized concealed beneath the drift here and there throughout the county; but so complete is the dissection into steep sided valleys that there is little chance to select the lines of preglacial drainage. The general slope of the surface of the Dakota sandstone suggests a general drainage toward the southwest. Doubtless the surface of the sandstone as developed during the long intervals of erosion from - the Cretaceous to the Pleistocene was changed during Aftonian interglacial times by further erosion; but so far as can now be ascertained a rugged surface as above described is that over which the earliest ice sheet, the Nebraskan, advanced. With fainter relief, because of imperfect erosion of Nebraskan drift from hillsides and valleys, it suggests the topography over which the Kansan ice sheet also spread and left the bowlder clay now so conspicuous on the hillsides.

\section{The Fault}

A continuation of that reported near Thurman, Fremont county. In 1889 J. E. Todd" stated that "The sharp fold... . which has 34. E. Todd, "On the Folding of the Carboniferous Strata in Southwestern Iowa,"
Proceedings of the Iowa Academy of Sclence, Vol. I, Part 1, p. 61, 1889. 14 
been noted at Jones' Point (Nebraska) may become a' fault south of Wilson's (Iowa)". In 1906 he $^{35}$ again called attention to the facts that had in the meantime been overlooked, and located the fault on the Iowa side close to the south line of section 23, between Thurman and Wilson's quarry, Fremont county. G. L. Smith ${ }^{83}$ calls attention to this displacement. $\mathrm{He}$ states that, "Recent examinations of exposures at Lake Wabonsie and in the vicinity of Thurman confirm the views of Todd and show that at a short distance south of the Wilson section of White a fault of about 300 feet $^{37}$ throw with an uplift to the north is present". He further, on page 636 of the same report, states the following: "The line of disturbance if extended in a direction north of east through Jones Point on the Missouri river in Nebraska and south of the Wilson section at Lake Wabonsie in Fremont county would pass a short distance south of Stennett. The fault near Lake Wabonsie has, probably, in the eastward extension, become an anticline, and the dip to the north at Stennett would indicate that the line of disturbance lies not far to the south of this place." The facts presented in this present report prove that this "line of disturbance" does extend past Stennett and Fox quarries, and that the facts warrant the recognition of a normal fault, rather than a monocline or a symmetrical anticline, though a slight anticline does, here at least, parallel the western side of the fault.

Charles R. Keyes in his map of the "Controlling Fault Systems of Iowa (Proc. Iowa Acad. Sci., Vol. XXIII, p. 103, 1916) maps this line of disturbance as a fault line but mentions no data for considering it a fault except by referring to Todd's statement with reference to relations near Wilson in Fremont county. His discussion of the "Extent and Age of the Cap-au-Gres Fault" in the Proceedings of the next year (p. 61) is certainly of interest and importance in connection with this present discussion. The line of disturbance which he traces parallels the eastern side of the Missouri escarpment through Illinois and Missouri into Iowa. The data on age of fault here presented, and the direction of the fault are worthy of attention in comparing the two fault lines, and noting the effect on Iowa topography near their possible intersection, which is four or five miles east of Earlham.

35J. E. Todd, "Some Variant Conclusions in Iowa Geology," Proceedings of the Jowa Academy of Science, Vol. XIII, p. 184. 1906. ${ }^{38} \mathrm{G}$. L. Smith, "Carbonlferous
Survey, Vol. XIX, p. 612,1909 .

ain plate 22 he gives it as 320 feet. In the computation in thls paper I have considered it to be 300 feet. 
Amount of Displacement. ${ }^{\text {ss }}$ - The amount of displacement can be ascertained by comparing relations in the southcentral part of the county with descriptions and well records such as are given by G. L. Smith in his "Carboniferous Section of Southwestern Iowa."

At Briscoe the shaft is reported to be $1253 / 4$ feet deep. It is $1201 / 2$ feet to the bottom of the coal, which places the bottom of the Nodaway coal at this point at $1,014.5$ feet above sea level, while the top of the limestone No. $9^{30}$ in the side of the excavation at Fox quarries is at 1,135 feet above sea level, a difference of 120.5 feet, which must be added to the thickness of the strata between the two horizons as recorded in well borings and sections, noting that the limestone at Fox quarries is Oread limestone (No. 78 of the Clarinda record).

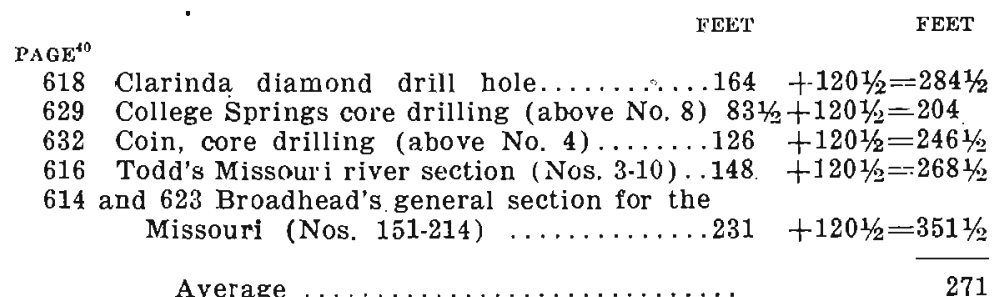

Of these places Clarinda is nearest to Cass county; so that the displacement is considered to be $2841 / 2$ feet. This happens to be near the average in the above table.

\section{ARGUMENT WITH REFERENCE TO THE FAULT.}

The question whether there is a fault or only a monocline involves 1 somewinat technical discussion that may prove oi little interest to the general reader of a county report, but the facts are so important to the geological worker that a discussion of the evidence cannot be omitted, especially when the presence of a fault in this part of Iowa has only been surmised, never substantiated. Indeed, in the literature of Iowa there is very little of exact evidence bearing on faults, except a few small ones found in coal mines. The practical importance with reference to the distribution of coal will receive further attention under the heading, Coal, in the chapter on Economic Deposits.

1. The displacement of 284.5 leet occurs within a maximum distance of two miles in a direction at right angles to the general dip through the entire region. This displacement is along the line of strike, and not due to local variation

${ }^{35}$ The facts given in the discussion of Correlation also bear on the question of lle amount of displacement.

"No. 5, used in local comparisons in a preceding chapter, is seven feet below No. !!. topages refer to G. L, Smith's "Carboniferous Eection of Southwestern Iowa." lowa Geological survey, Vol. XIX. Broadhead's section is more completely given in Hinds and Greene's "Stratigraphy of the Pennsylvanian in Missouri," pp. 112-113. 


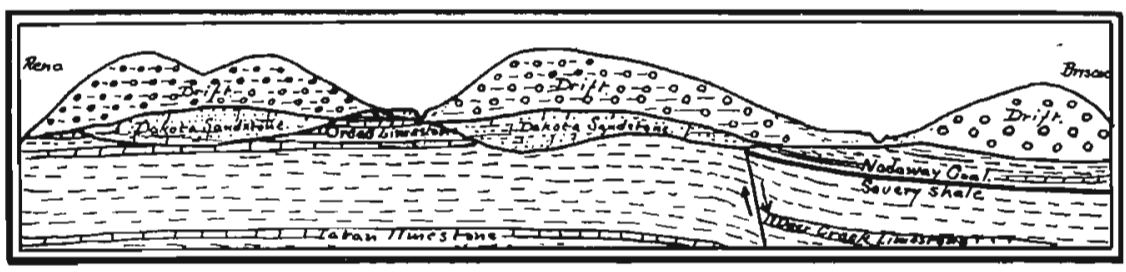

Fig. 31.-Diagram representing conditions from near Reno, Edna townshlp, Cass county, southeast to Briscoe, Adams county, across the fault plane.

in the general dip of the region. The fracture itself is parallel, or nearly parallel, to the general direction of dip, and is thus to be classed as a dip fault, or slightly oblique normal fault. Work to the northeast by the writer indicates a curve in the direction of displacement due to multiple faulting "en echelon."

2. A line of disturbance running N. $62^{\circ}$ E. between Briscoe and Fox quarries with a displacement of 284.5 feet within a maximum distance of two miles would, if the dip were uniform the entire two miles, require a slope of but $1^{\circ} 32^{\prime} 45^{\prime \prime}$, or 142.5 feet to the mile. If the dip in the strata changed from one level to another across the displacement the dip in the steepest place must be several times this amount, but the dip at the extreme ends could not, in a monocline, be several times the average dip for the whole distance.

At Fox quarries the dip is about what the average dip should be for a mono-. cline; but at Briscoe it is nearly twice too much and at Stennett, located similarly to Fox quarries with reference to the plane of disturbance, the dip is also nearly twice too much for a monocline. Under this second heading, then, the argument favors the presence of a fault, though it is not fully conclusive.

3. Stretching resulting in a monocline tends toward uniformity in direction of dip. Along a thrust fault the strata are mashed and contorted, the angle is low, and the uneroded remnants of resistant strata on the upthrow side may extend far beyond exposures of downthrow strata in the valleys. Along a normal fault the strata are not mashed and contorted, though accompanying irregular pressure may vary the direction of dip near the fault. The angle is high and the uneroded remnants of successive beds of resistant strata may zigzag across the surface, but the border does not depart from the plane of fracture.

The dips measured at the different locations do not agree in direction. The dip found at Stennett makes an angle of only $28^{\circ}$ with the general direction of the plane of disturbance and that angle is toward the east side. At Fox quarries the direction of dip makes an angle of $52^{\circ}$ with the general direction of the plane of disturbance and that angle is toward the west side. The dips at the two places thus make an angle of $100^{\circ}$ with each olher; and the dip at stennett is about at right angles to the dip at Briscoe.

At Spring creek and Lewis, about eight miles from the line of disturbance, the dip is in the opposite direction from that at Fox quarries.

Smith also records a "heavy dip to the north" at Stennett. This seems to be at some place near Stennett having a:relation to the fault plane similar 
to that at Lewis. The measurement of dip recorded in this present report was made about half a mile north of the railroad station, on thick limestone in an old quarry close to the track.

4. If a fault is present the Nodaway coal seam, wherever it is below the level of the Dakota sandstone and the preglacial surface, stops against the fault plane. If there were a monocline instead of a fault, the coal would come to the Dakota sandstone or to the glacial drift, between Briscoe and Fox quarries. The absence of evidence of coal along this line favors the presence of a fault; but the lack of well records in this area and the presence of high ground a part of the way leave evidence here far from satisfactory.

It is not possible to apply this test to the east and west of the above named location because of the following relation: A mile west of Fox quarries the Nodaway coal outcrops along Williams Branch ${ }^{41}$ where it was formerly mined. Here it has risen fifty-eight feet above the level of its position at Briscoe. only three miles away, and it is not reported further west in "Montgomery county. Here, on the south side of the fault, the strata have a large component of their dip, or all of it, in an easterly direction, from Williams Branch toward Briscos, where the dip found is to the south. In the opposite direction from the Briscoe-Fox quarry region, northeast of Briscoe, the Nodaway coal is still deep in the ground up to the fault plane across the southeast half of Victoria township, Cass county. On to the northeast the strata rise till the base of the Missouri appears near Winterset.

5. The dip at Williams Branch has not been measured; but from the relation between conditions at Williams Branch and those at Briscoe it is clear that there is at least a large component of dip straight east, at right angles to the dip at Briscoe three miles away. This is an extreme of irregularity.

6. The dip of $3^{\circ} \mathbf{E}$. at Stennett has a component of five-sixths of that amount toward Williams Branch. This component of $2.5^{\circ}$ would give a displacement of 253.6 feet, which is five times too much for the actual displacement between Deer Creek limestone at Stennett and Nodaway coal at Williams Branch. This again indicates some cause of excessive local dip--slipping rather than monocline.

7. Comparing relations between conditions at Williams Branch with those at Fox quarries the argument is still more conclusive. These places are only a mile apart in a direction diagonal to the plane of disturbance and making an angle of $27^{\circ}$ with it, giving a distance of half a mile as measured perpendicularly to the plane of disturbance. Within this half mile lies the plane of disturbance having a displacement at this point of close to 232 feet, which would require an average dip of $5^{\circ} 8^{\prime} 27^{\prime \prime}$, which is uearly three times the dip found at Fox quarries and nearly two times the dip found at Briscoe.

In the above, 1 is strongly for the presence of a fault, 2 is somewhat of value, 4 is worthy of notice but of little value in evidence, and 3 , supported by 5 , 6 , and 7 , forms a strong argument in favor of a fault.

8. If the plane of disturbance were vertical the plane would outcrop across the country with direction independent of the topography. If the plane dipped to the northwest, the plane at the more resistant strata on the northwest side

"E. H. Lonsdale, "Geology of Montgomery County," Iowa Geological Survey, Vol. IV, p. 403. 
would curve southeast, and the plane at the outcropping of less resistant strata on that side would curve to the northwest of the general direction of the line of disturbance, the amount of variation from the general direction depending on the angle of dip of the fault plane. With the downthrow on the southeast side this relation would be that of a thrust fault. If the plane dipped to the southeast the plane of resistant strata, the preglacial high ground on the southeast side, would curve northwest, and the plane at the outcropping of the less resistant strata, the preglacial low ground on the southeast side, would curve southeast of the general direction of the line of disturbance, in amount inversely to the angle of dip.

In the fleld it seems clear that the line of outcrop does not vary much from a straight line, or one that gradually curves, which corresponds to conditions where the angle is high.

With the downthrow on the southeast side, and with excessive folding and crushing absent though there is local variation in direction of dip at different points along the plane, it is evident that the fault is a normal fault, with the fault plane between Briscoe, or the old coal mine on Williams Branch on one side and Fox quarries on the other, with fault plane not far from vertical, and dipping steeply to the southeast. This judgment can be tested whenever the operators of the Briscoe mine care to extend their entries sufficiently far to the northwest, apparently 2,454 feet, to find out how the coal ends in that direction. Unfortunately there are some conditions common to both possibilities. If there were a monocline the coal would thin out with stretching, breaking and weathering, but not reach sandstone because of weathering in pre-Dakota time. Possibly it might reach bowlder clay at points where the sandstone and. Missouri strata have been removed by erosion in preglacial time. With a fault plane present the coal may end squarely against the fault plane, or, with coal either weathered or not weathered, end against sandstone or bowlder clay south of the fault plane; but it would not thin out with stretching and breaking.

Todd"2 states, "A careful comparison of sections on both sides of the (Missouri) river shows two anticlines, the higher with its crest near Plattsmouth, and the other about one and a fourth miles above Jones' Point." G. L. Smith distinctly figures a normal fault on the Iowa side in Plate $22^{45}$, but represents a thrust fault on page 649. Assuming the fault to be a normal one at Thurman, as seems probable, and with throw of 300 feet recorded by Smith, this fault continues northeastward with little diminution through the space between Fox quarries and Briscoe, where the throw is $2841 / 2$ feet on the same side as at Thurman. To the northeastward the fault line crosses the county line at the northeast corner of Victoria township, but no more data with reference to it are at present obtainable in Cass county. In the next county east, Adair, it lies close north of Bridgewater, passes close to Fontanelle, and, bending slightly northward, lies a short distance northwest of Greenfield and of Arbor Hill $^{44}$. It seems to be completely concealed beneath the Dakota sandstone and the drift in this part of the state.

\footnotetext{
${ }^{2} \mathrm{~J}$. E. Todd, "Some Variant Conclusions in Iowat Geology," Proceedings of the Iowa Academy of Science, Vol, XIII. p. 184, 1906.

Iowa Geological Survey, Vol. XIX, p. 646.

"In the report on the Geology of Adair County, Iowa" may be found a continuation of this discussion based on data found in that county.
} 
Southeast of this fault line the coal found at Bridgewater is correlated with the Nodaway coal; and the successive limestone beds outcrop farther to the east than the same beds outcrop on the northwest side of the line. Northwest of this fault line the Eureka shaft (section 4, Eureka township, Adair county) had a depth of 212 feet below the upland and passed completely through the Missouri stage into the Des Moines stage. The Des Moines stage itself comes to the surface three miles beyond Stuart, ${ }^{40}$ and the northern boundary of the Missouri stage curves off to the west.

If the throw along the fault plane were to continue, to diminish at the same small rate with which it diminishes between Thurman and Fox quarries, and - the direction were to hold as constantly, the fault would continue northeastward beyond the limits of the state. It would pass five miles east of Earlham, would lie four or five miles north of Des Moines, in which region it may at some time be encountered in mining for coal. Possibly uear the surface it dies out rapidly in the Des Moines shales. Possibly it may meet an extension of the Cap-au-Gres faul, which Keyes thinks extends northward from Missouri to Leon, and both may die out abruptly near their intersection. Here are problems in Iowa Geology for future study, with important bearing on the question of depth and continuity of coal seams.

Note also the northeastward extension and high position of the Winterset and other limestone in Madison county. Heretofore it has been recognized as an uneroded remnant; but why its peculiar attitude? This has been a puzzle. The presence of the limestone and accompanying shale so far to the northeast in Madison county is explained by its relation to the Thurman iault plane whatever bearing future developments may have with reference to an extension of the Cap-au-Gres fault. The limestone and shale are not an uneroded mass of uplifted strata, but are the uneroded remnant of a mass of limestone and shale on the downthrow side, left high and further to the northeast because of the greater erosion and peneplanation on the upthrow side to the northwest and north, in which directions erosion brought to the preglacial surface. the less resistant shales of the Des Moines stage. We must await further evidence with reference to conditions in the drift-filled valleys along the eastern side of the escarpment.

To the northeast, along the general direction of the fault plane described in this report, there are pecullarities in the distribution of the Devonian, Silurian and Ordovician strata that need explanation. It cannot at present be affirmed whether the fault, or a series of-parallel faults is responsible for that distribution, or whether the disturbance there becomes a symmetrical anticline. .

\section{AGE OF' THE FAULT.}

Since the Dakota sandstone lies on both sides of the fault plane and rests on the truncated surface of various strata of the Missouri stage with no evidence of a fault scary beneath the Dakota sandstone, it appears that the faulting began in the

\footnotetext{
${ }^{45}$ Charles $R$ Keyes, "Coal Deposits of Iowa," Iowa Geological Survey, Vol. II, p. 442 ; also, Henry Hinds, "The Coal Deposits of lowa," lowa Geological Survey, vol. Xix, p. 379

${ }^{8} \mathrm{H}$. F, Bain, "Geology of Guthrie County," Iow.a Geological Survey, Vol, VII, Map.
} 
interval between the deposition of the Missouri strata and the deposition of the Dakota sandstone, that the fault scarp was well removed before the subsidence that accompanied the deposition of the Dakota sandstone, and that any additional faulting since that time has not been very pronounced. That there has been some later movement is evident, since at Crystal Lake the sandstone strata are found to dip in the general direction of the dip of the Missouri limestone. If there was any movement along the fault plane any escarpment formed at the surface of the sandstone has since been removed by erosion.

Variations in dip of the sandstone that correspond to variations in dip of the limestone along the fault plane have not been detected. It therefore appears from this argument also, that about all faulting with accompanying disturbance was completed before the Dakota sandstone was laid down. In this interval of time there was one marked age of disturbance, the Permian. In distant regions, the Appalachian and Ouachita mountains, the faulting was of the reversed type. Here it is of the normal type. The reversed faulting of the Permian may have been accompanied or followed by relaxational movements in the same or the next period. To this interval of time (Permian-Triassic) it seems at present necessary to refer the major part of the faulting and perhaps all of it.*

\section{Joints}

In the Dakota sandstone at Crystal Lake, a mile south of Lewis, two sets of master joints are to be seen in the sandstone, the first of the two sets being the more prominent:

Direction of joint plane N. $75^{\circ}$ E., with dip of $83^{\circ}$ in a direction N. $15^{\circ} \mathrm{W}$.

Direction of joint N. $8^{\circ} \mathrm{W}$., with dip of plane vertical.

The sandstone is crossbedded, but included shale dips $6^{\circ}$ in a direction $\mathrm{S} .30^{\circ} \mathrm{W}$.

A simple movement bringing the shale into a horizontal position would throw the vertical joint plane $2^{\circ} 32^{\prime}$ out of plumb and leave the other plane with a dip of $86^{\circ}$.

* See also John L. Tilton, "The Thurman-Wilson fault through southwestern Iowa and its Bearings": The Journal of Geology, Vol. XXVI, pp. 383-390, 1919. 
A depression in a direction N. $8^{\circ}$ W., the direction of the vertical joint, sufficient to bring the direction of dip in the shale into a horizontal plane would require a depression of $10^{\circ} 23^{\prime}$, the axis (strike) of the movement lying $\mathrm{N}$. $82^{\circ} \mathrm{E}$, and would give the shale a dip to the northwest. This depression is $2^{\circ} 45^{\circ}$ too much to bring the other plane into a vertical position, and would at the same time change the direction of the strike slightly toward the north. This approximate adjustment is so close that if a part of the dip of the shale had been due to a slight local variation in amount or direction, or both, the chief need would be met. This local variation seems possible where the shale is between crossbedded sandstones, as at Crystal Lake. To further effect an adjustment a variation in the neture of a warping also seems necessary. The conclusion seems warranted tnat, reversing the movement for the above adjustment, these joints in the Dakota sandstone were caused by uplift toward the northwest, the direction of which changed in warping from a westward toward a northward direction (N. $15^{\circ}$ W. to N. $8^{\circ}$ W.) Such an estimate based on present dip includes not only post-Cretaceous movement but also such later movements as may have occurred. Uplift toward the northwest might not only affect, in the underlying limestone, Joints at right angles to this direction but even lead to some additional faulting along the faul plane.

In the Missouri stage limestone at Spring creek two miles northwest of Crystal Lake, the directions of the joints were found to be as follows: N. $391-3^{\circ}$ E. and N. $202-3{ }^{\circ}$ W., where the dip of the limestone was found to be $3^{\circ} 45^{\prime}$ in a direction $\mathrm{N}$. $5^{\circ} \mathrm{E}$. If these limestone beds were subjected to the same movement that was suggested for the overlying sandstore the dip of the limestone would be increased. Furthermore, the dip of the limestone is found to be different in places distant from each other. It is therefore evident that the limestones were subjected to movement prior to those that affected both the limestone and the sandsone.

The two sets of joints in the limestone do not correspond exactly to those in the sandstone, but are even more closelv related to the direction of the fault plane, and to the uplift toward the northeast. The joint that extends N. $391-3^{\circ} \mathrm{E}$. is nearest in direction to that of the fault plane, which locally extends N. $62^{\circ}$ E., and to the direction of the uplift, that is northeast. The joint that extends N. $202-3^{\circ} \mathrm{W}$. is approximately at right angles to this general direction of the fault plane and the uplift.

The jointing in the Missouri stage thus seems related to the faulting and to the Permian uplift toward the northeast, while the jointing in the sandstone is related to the post-Cretaceous uplift toward the northwest, though it is affected by the presence of the fault plane and the existing joint planes, and also affects those planes. 


\section{CENOZOIC GROUP. TERTIARY SYSTEII.}

\section{Pliocene Series (Ozarkian)}

The last part of the Tertiary Period is marked by uplift and accompanying erosion, both in the East and in the West. In eastern Iowa it is marked by valleys 100 to 200 feet $^{47}$ below the level of the present stream beds. In southcentral Iowa it is marked by valleys sixty-five feet ${ }^{* \mathbf{s}}$ below the present stream beds, containing deposits that were recognized as preglacial. In Cass county it is marked by valleys that are twenty-five feet below the present stream beds. In some of these deep valleys are silts that are beneath Nebraskan drift and hence are of preglacial deposition. Whether they were laid down long prior to the advancing continental glaciers, or were laid down immediately in front of the advancing Nebraskan ice sheet, cannot be affirmed; but certain it is that as the Nebraskan ice advanced it covered up in these old valleys bodies of silts which were rich enough in vegetable matter to become sources of abundant carbon dioxide even to the present time, and hence are recognized as bogs beneath Nebraskan drift, and at too great depth to be Aftonian deposits.

Ten wells (numbers $2,4,5,9,10,11,12,13,17,18$ in the table below) reach boglike deposits beneath Nebraskan drift or at depths that seem undoubtedly to lie beneath the level of Aftonian deposits. Two other wells (numbers 7 and 8 ) in Franklin township which lie close to wells that undoubtedly reach the base of the Nebraskan drift and which appear to reach the same deposits though at different depths, are included as reaching preglacial deposits. In the other records there is not the degree of certainty that there is in the above twelve, as the depths are not so great: In some of them there appears to be a distinct record of the presence of a weathered clay beneath the waterbearing sand and gravel. Though a pocket of sand within drift might prove a fairly good water-carrier, an abundance of water

\footnotetext{
${ }^{47}$. H. Gordon, "Burjed River Channels in Southeastern Iowa," Iowa Geological Survey, Vol. III p. $239,1893$.

Charles $R$. Keyes, "Geology of Lee County," Iowa Geological Survey, Vol. III, Plate 28,1893

J. Erinest Carman, "The Mississippi Valley between Savannah and Davenport," Bull. No. 13, Illinois State Geological Survey, p. 28, 1909.

James H. Lees, "Earth Movements and Drainage Lines in Iowa," Proceedings of the Iowa Academy of Science, Vol. XXI, pp. 176-177, 1914.

"John L. Tilton, "lhe Pleistocene Deposits of Warren County, Iowa," p. 16, 1911.
} 
would indicate that the sands are extensive, and generally either preglacial or Aftonian. Because of the depth at which abundant sands were encountered it is thought best to list these wells also with those that reveal the presence of preglacial deposits.

PREGLACIAL BOGS AND OTHER DEPOSITS

\begin{tabular}{|c|c|c|c|}
\hline No. & Twp. & Section & Data \\
\hline 1 & Pymosa & $\begin{array}{l}\text { Ne. 1/4 of the Se. qr. } \\
\text { of section } 17 .\end{array}$ & $\begin{array}{l}12 \text { feet of red sand are beneath } 177 \\
\text { feet of yellow and blue clay, on yel- } \\
\text { low clay. }\end{array}$ \\
\hline 2 & Benton & $\begin{array}{l}\text { Ne. } 1 / 4 \text { of the Sw. qr. } \\
\text { of section } 9 .\end{array}$ & $\begin{array}{l}\text { Gas comes into water in a well } 263 \\
\text { leet deep. }\end{array}$ \\
\hline 3 & Benton & $\begin{array}{l}\text { Ne. } x / 4 \text { of the Nw. qr. } \\
\text { of section } 26 \text {. }\end{array}$ & $\begin{array}{l}18 \text { feet of quicksand are under } 174 \\
\text { feet of yellow and blue clay; and } \\
\text { rest on yellow clay. }\end{array}$ \\
\hline 4 & Grant & $\begin{array}{l}\text { Ne. } 1 / 4 \text { of the Ne. qr. } \\
\text { of section } 5 \text {. }\end{array}$ & $\begin{array}{l}\text { Wood said to be "petrifed" at depth } \\
\text { of } 87 \text { feet, in white sand beneath } \\
\text { blue clay and above hard rock. } \\
\text { Much gas bubbles out, and water } \\
\text { seems oily in the winter time. } \\
\text { Water rose } 50 \text { feet. }\end{array}$ \\
\hline 5 & Grant & $\begin{array}{l}\text { Anita, old city well, } \\
\text { Nw. 1/4 of the Se. qr. } \\
\text { of section } 21 \text {. }\end{array}$ & $\begin{array}{l}\text { "Mineral" water at } 180 \text { leet, just } \\
\text { below the blue clay. The water } \\
\text { may come in part from Dakota } \\
\text { sandstone. }\end{array}$ \\
\hline 6 & Washington & $\begin{array}{l}\text { Se. } 1 / 4 \text { of the } \mathrm{Nw} \text {. qr. } \\
\text { of section } 11 \text {. }\end{array}$ & $\begin{array}{l}\text { Coarse gravel and sand are under a } \\
\text { thick blue clay in a well that is } 187 \\
\text { feet deep. }\end{array}$ \\
\hline 7 & Franklin & $\begin{array}{l}\text { Se. } 1 / 4 \text { of the } N w \text {. qr. } \\
\text { of section } 23 \text {. }\end{array}$ & $\begin{array}{l}12 \text { feet of sand are beneath } 155 \text { feet } \\
\text { of yellow and blue clay; and on } \\
\text { clay. }\end{array}$ \\
\hline 8 & Franklin & $\begin{array}{l}\text { Se. } 1 / 4 \text { of the Ne. qr. } \\
\text { of section } 23 \text {. }\end{array}$ & $\begin{array}{l}\text { The well stops at } 167 \text { feet in water- } \\
\text { bearing sand on clay. }\end{array}$ \\
\hline 9 & Franklin & $\begin{array}{l}\text { Sw. } 1 / 4 \text { of the Sw. qr. } \\
\text { of section } 24 \text {. }\end{array}$ & $\begin{array}{l}\text { There was a strong flow of gas as } \\
\text { the operator struck the sandstone } \\
\text { at a depth of } 175 \text { foet. }\end{array}$ \\
\hline 10 & Franklin & $\begin{array}{l}\text { Se. } 1 / 4 \text { of the Sw. qr. } \\
\text { of section } 36 \text {. } \\
\text { also } \\
\text { Ne. 1/4 of the Nw. qr. } \\
\text { of section } 36 \text {. }\end{array}$ & $\begin{array}{l}\text { Gas troubled them as they left the } \\
\text { blue clay (at } 178 \text { feet) and entered } \\
\text { what is supposed to be limestone. } \\
\text { The water appears oily after stand- } \\
\text { ing. The gas puts out the flame of } \\
\text { a lantern (carbon dioxide). }\end{array}$ \\
\hline 11 & Lincoln & $\begin{array}{l}\text { Se. } 1 / 4 \text { of the Sw. qr. } \\
\text { of section } 3 \text {. }\end{array}$ & $\begin{array}{l}\text { Ends in sand beneath } 232 \text { feet or } \\
\text { blue and yellow clay. The water } \\
\text { is hard and stands at } 120 \text { feet deep } \\
\text { in well. }\end{array}$ \\
\hline 12 & Lincoln & $\begin{array}{l}\text { Se. } 1 / 4 \text { of the Nw. qr. } \\
\text { of section } 4 .\end{array}$ & $\begin{array}{l}\text { The well stops in } 20 \text { feet of sand } \\
\text { below } 220 \text { feet of yellow and blue } \\
\text { clay. }\end{array}$ \\
\hline
\end{tabular}




\begin{tabular}{|c|c|c|c|}
\hline No. & Twp. & Section & Data \\
\hline 13 & Lincoln & Center of section 35 . & Quicksand and gas were found. \\
\hline 14 & Beargrove & $\begin{array}{l}\text { Nw. } 1 / 4 \text { of the Nw. gr. } \\
\text { of section } 11 .\end{array}$ & $\begin{array}{l}12 \text { feet of sand and gravel are be- } \\
\text { neath } 160 \text { feet of yellow and blue } \\
\text { clay, and rest on a clay. }\end{array}$ \\
\hline 15 & Union & $\begin{array}{l}\text { Se. } 1 / 4 \text { of the Ne. qr. } \\
\text { of section } 9 .\end{array}$ & $\begin{array}{l}\text { Well ends in sand and gravel at a } \\
\text { depth of } 100 \text { feet. }\end{array}$ \\
\hline 16 & Union & $\begin{array}{l}\text { Creek bed, sections } \\
10 \text { and } 11 .\end{array}$ & $\begin{array}{l}\text { For two miles the creek bed has } \\
\text { springs in it, and there are springs } \\
\text { in the low ground. }\end{array}$ \\
\hline 17 & Massena & $\begin{array}{l}\text { Sw. } 1 / 4 \text { of the Sw. qr. } \\
\text { of section } 4 .\end{array}$ & $\begin{array}{l}\text { Well 250 feet deep; stopped in } \\
\text { something that had oak in it. }\end{array}$ \\
\hline 18 & Massena & $\begin{array}{l}\text { Sw. } 1 / 4 \text { of the Se. qr. } \\
\text { of section } 6 .\end{array}$ & $\begin{array}{l}\text { The well ends in sand and gravel } \\
\text { beneath } 254 \text { feet of yellow and blue } \\
\text { clay. }\end{array}$ \\
\hline 19 & Edna & $\begin{array}{l}\text { Sw. } 1 / 4 \text { of the Nw. qr. } \\
\text { of section } 21 .\end{array}$ & $\begin{array}{l}14 \text { feet of quicksand are under } 114 \\
\text { feet of yellow and blue clay, and } \\
\text { rest on yellow clay. }\end{array}$ \\
\hline
\end{tabular}

Some of the above wells mark two areas where there are bogs covered by drift. One group is near the southeast corner of Franklin township; the other, in the northeast corner of the county, in an area apparently extending into both Audubon and Adair counties. They also mark areas where shale rather than limestone is beneath the Dakota sandstone, where the latter is present, and the drift (see geological map of the county), thus marking preglacial low ground. Because of this relation it seems very possible that the "clay" recorded in several instances as beneath the water-bearing sand is not bowlder clay but water-soaked shale.

In section 36 of Franklin township a lighted lantern lowered into the covered pit above the well was quickly extinguished, proving that the gas would not burn ${ }^{49}$ nor support combustion.

From the amount of decomposition that has led to an abundant flow of carbon dioxide in this region (sections $24,25,35$ and 36 , Franklin township) it is evident that here is the site of an ancient bog.

In the northern part of Grant township the two wells where gas was reported and two others in which logs were encountered at or near the level at which gas was found, indicate a consid'?

19For fear of possible explosion the writer did not consent to this test till he was informed by those present that they had taken a lantern Into the plt before that time when at work upon the well. 
able distribution of such conditions. Apparently a bog extends into Audubon county on the north and into Adair county on the east.

In northern Union township also there are conditions that can be satisfactorily explained only by the presence of deposits similar to those in the above named regions. Here for two miles (sections 11 and 12) the trench of the creek was well supplied with water from springs in and close to the creek bed during hot weather when all else was dry. That it was not entirely the drift that supplied this water seems evident, for the owner of one of the springs said he had pushed a twelve-foot pole down into one of the springs without reaching the bottom of the mud. This spring is but two miles southwest of the well where the gas was tested, and at the same level as the beds that supplied the gas.

Southwest of Massena for a distance of six miles there are numerous springs of water that make the West Nodaway an unfailing stream, the water coming from sand and Dakota sandstone at the base of the drift.

Preglacial Relief.-WThe highest hills of Dakota sandstone that have been noted are fifty feet below the level of the upland, and the lowest preglacial deposit found is in a well 254 feet deep. This gives a maximum preglacial relief of 204 feet. It may have been somewhat greater because of Aftonian erosion of exposed hills.

\section{CENOZOIC GROUP. QUATERNARY SYSTEM.}

\section{Pleistocene Series}

General.-The bowlder clay, or drift, is composed of a mixture of clay, sand and gravel with pebbles and bowlders in it here and there that were left in a confused mass by continental glaciers of former times. Material of this character may be seen in many of the ravines in all parts of the county, particularly in such parts as have been gullied in time of rain. The material of the drift stands in marked contrast with the stratified limestone, shale and sandstone above which it lies. While it varies greatly in its composition from place to place, in some places containing lenses of sand, in others being almost free 
from sand and pebbles, and in still others being full of pebbles and of clay cemented with iron oxide, it may generally be recognized as simply an intimate mixture of clay and many kinds of pebbles. To this there is one important exception. Where the drift has undergone long continued weathering ${ }^{50}$ without disturbance of residue, the product is called a gumbotil. ${ }^{51}$ The planes of gumbotils are marked horizons, indicating the upland portion of the particular drift considered (Nebraskan or Kansan for Cass county).

The average thickness of Pleistocene deposits beneath the upland as found in 108 wells that reach through these deposits is 150 feet. The separate records vary from 30 feet in Grant and Edna towuships to 250 feet in Grant and Massena townships and one of 254 feet in Massena township, and are very variable throughout the county. The averages by townships vary from 111 feet in Cass township, to 195 feet in Massena township.

In Iowa as a whole there are materials representing five distinct glacial stages, separated by evidences of four interglacial stages. The relation of these is expressed in the following table, in which the oldest is at the bottom:

Wisconsin stage (glacial).

Peorian stage (interglacial).

Iowan stage (glacial).

Sangamon stage (interglacial).

Illinoian stage (glacial).

Yarmouth stage (interglacial).

Kansan stage (glacial).

Aftonian stage (interglacial).

Nebraskan stage (glacial).

Of the glacial stages but two are represented in Cass county: the Nebraskan and the Kansian. Of the interglacial stages but two can be distinctly recognized: the Aftonian and the Yarmouth. Deposits of the other stages are found elsewhere in the state. In Cass county the various post-Yarmouth changes are

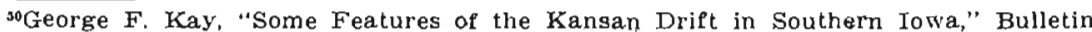

Geological Society of America, Vol. 27, pp. 115-117. Series, Vol. 44, 1916. See also Iowa Geological Survey, Vol. XXVI, p. 217.
} 
marked by valley cutting and filling, affording a means of correlation of events here with events in the central and eastern parts of the state, and also in other parts of the country.

\section{NEBRASKAN STAGE}

The first ice sheet that is recognized is the Nebraskan, ${ }^{52}$ whicn, gradually accumulating and pushing southward, brought to the confines of the county its load of mingled. soil, clay, sand, gravel and bowlders from the north, mixed with local material gathered from nearer at hand. After the melting of the ice the surface material that was left behind was subjected to long-continued chemical change without marked disturbance of material, so that a gumbotil was developed. Since this long-continued weathering, changing the surface deposits of a glacial drift into a gumbotil, occurred in Aftonian time, the gumbotil is considered an Aftonian product of weathering, and is not classified as $\mathrm{Ne}$ braskan drift. ${ }^{53}$.

The general body of the Nebraskan drift is well exposed along the east and west road a mile south of Atlantic (south of section 8, Grove township). Here beneath the Nebraskan gumbotil the blue Nebraskan drift contains pebbles of red quartzite, greenstone, light granite and quartz, such as are found in the Kansan drift, except that no dark decomposed granites were seen, and at this point the yellowish, oxidized upper portion was absent. The Kansan drift is here present above the Nebraskan gumbotil, but the Kansan gumbotil has been eroded away.

Well Records.-All of the wells listed as presenting evidence of the presence of preglacial deposits also contain evidence of Nebraskan drift below the level of the Aftonian stage. To that list may be added two other records that reveal the presence of this deep-lying drift without evidence as to the character of the preglacial deposits, though the inference is certain that the wells derive water either from preglacial deposits or from the Dakota sandstone beneath the drift.

\footnotetext{
"3:B. Shimek, Aftonian Sands and Gravels in Western Iowa," Geological Society of America, Vol. 20,1909 , p. 408 .

${ }^{3} W$. C. Alden and $M$. M. Leighton. "The Iowan Drift. a Review of the Evidences of the Iowan Stage of Glaciation," Iowa Geological Survey. Vol. XXVI, p. 57, 1915.
} 


\begin{tabular}{|c|c|c|c|}
\hline No. & Twp. & Section & Data \\
\hline 20 & Grant & $\begin{array}{l}\text { Se. } 1 / 1 \text { of the Ne. qr. } \\
\text { of section } 2 \text {. }\end{array}$ & $\begin{array}{l}\text { Went through a "stump" far down } \\
\text { in a well } 252 \text { feet deep. }\end{array}$ \\
\hline 21 & Washington & $\begin{array}{l}\text { Ne. } 1 / 4 \text { of the Ne. qr. } \\
\text { of section } 7 .\end{array}$ & $\begin{array}{l}50 \text { to } 60 \text { feet of sand and gravel lie } \\
\text { between two blue clays in a well } \\
\text { that is } 210 \text { feet deep. }\end{array}$ \\
\hline
\end{tabular}

Thickness of Nebraskan Drift.-The Nebraskan drift extends from about ninety feet below the upland, just beneath the $\mathrm{Ne}$ braskan gumbotil, to twenty-five feet, or a little more, below the river beds, a maximum for the county of about 176 feet. Six of the wells that reach the bottom of it give thicknesses varying from 120 to 173 feet, with an average of 148 feet. The minimum thickness is zero, where the hills of Dakota sandstone reach above the Nebraskan gumbotil plane, and where, especially along the river and larger creeks, erosion has proceeded to such an extent as to remove the Nebraskan drift. Because of the irregular preglacial surface, and also because of post-Kansan erosion, the present thickness of the Nebraskan drift differs greatly from point to point.

With a maximum thickness of 176 feet the drift would not completely obliterate a preglacial relief of 204 feet and control the early Aftonian topography. The difference between the two, twenty-eight feet, would mark here and there depressions in the early Aftonian surface, to guide the early drainage in a general way along preglacial lines, or mark swamplike depressions (kettles).

\section{AFTONIAN STAGE}

After the disappearance of the Nebraskan ice sheet the upper part of the drift left by the ice was subject to weathering and later to erosion till the advance of the Kansan ice sheet. The interval of time is known as the Aftonian interglacial age. In this time the upper part of the Nebraskan drift lost its small pebbles by solution, and the large ones were reduced till there were left only small smooth ones of the more resistant rock, such as quartz, chert and greenstone. During the same time the clayey portion of the drift was weathered to a gray to drab colored 
tenaceous clay called gumbotil. ${ }^{54}$ This gumbotil is now exposed here and there as a result of later erosion.

In the present stage of erosion the Aftonian upland surface of Nebraskan gumbotil can be seen along the roads well down the hillsides of large ravines where there are freshly cut ditches, revealing the horizontal dark band of gumbotil in contrast with the bowlder-bearing drift above and below. It outcrops by the roadside between sections 25 and 26 of Brighton township, along the southern boundary of sections 2, 3, 4 and 7 of Pymosa township, the east sides of sections 7, 18 and 25 and the south side of 23, Benton township, the east side of sections 29,32 and 33 and the south of 19 , the center of 28 and the north center of 29 , Grant township. In the next tier it is seen in abundance in the northwest part of Washington township in sections $5,6,7,8,17$, 18 and 19. In Grove township it was detected in sections 8 and 17, and sections 25 and 26. In Franklin it appears in the northern part of section 10. In Cass township it is seen in the southeast quarter of section 7. In Union township it is exposed along the west and north sides of section 24 ; in Pleasant township along the north side of section 36; and in Victoria in the southeast quarter of section 6 . These are by no means all the places, but they are sufficient to reveal the distribution. Exposures are, of course, wanting where the road is above the level of the gumbotil and where loess and washed material is banked in upon it, and the character of the material is doubtful in places not here included, where the road is at the level of washed material from the hillsides. It is only where the cut is deep enough to reveal the horizon of soil-like material that exposures are clear. In some of the places where it was not found it may have been removed in erosion during the Aftonian initerglacial interval.

In the southern part of the county the level of the Nebraskan gumbotil is approximately 80 feet below the common level of the upland. Immediately south of Atlantic it is 58 feet below a low upland, and is here at 1,234 feet above sea levell. At Cumberland it is at 1,228 feet above sea level, and at Bridgestee the previous general discussion of the Pleistocene Series. A further discussion of gumbotil is presented under the Yarmouth Stage. The Nebraskan gumbotil. here discussed, was first recognized by Professor George F. Kay, State Geologist, and traced across a considerable portion of the state. 
water it is at 1,218 feet above sea level. In the county as a whole it is at approximately 1,220 feet above sea level. It appears to be higher in the northwestern part of the county than in the southeastern part. ${ }^{.5}$

In wells that reached deposits of sand or muck with an abundance of water the deposits are definitely preglacial, or so closely related to that horizon that variations in depth seem dependent on variations in level of the preglacial surface. There are two wells ${ }^{\text {bo }}$ in which quantities of sand were found at about the horizon of the Aftonian stage, but these deposits are local. There are elsewhere extensive bodies of sand, but they are found to be post-Yarmouth in age, and are described under that heading. No sections of Aftonian bogs have been recognized where the surface of the Nebraskan drift and gumbotil are exposed.

For the Aftonian surface, then, we are left in this county with evidence only of the horizon of the Nebraskan gumbotil. The measurements from the general level of the upland mark this as a plane gently sloping to the southeast, but the conditions of measurement are not such as to record in this county such undulations and valleys as may have existed in the Aftonian surface. No evidence of the presence of former kames and gravel ridges associated with the Nebraskan gumbotil has been detected. All such features seem to have disappeared in the weathering to which the surface of the Nebraskan drift has been subjected.

For comparison it may be noted that two miles west of Murray, Clarke county, there is an extensive Aftonian bog. The Nebraskan gumbotil is at a level of sixty feet below the level of the upland, the top of the bog deposits ninety feet, and the bottom of the bog about one hundred eighteen feet. This gives a final Aftonian relief of thirty feet, and a valley filling of twenty-eight feet, a total of fifty-eight feet. There are no beds of limestone or sandstone that rise above the level of the gumbotil plain.

At Indianola, Warren county, the gumbotil plain, as seen in a valley northwest of the city, is forty-four feet below the top of the Simpson College well, in which, at a depth of one hundred twelve feet, a foot of water-bearing gravel and pebbles rests on limestone and lies beneath twenty-five feet of Aftonian

\footnotetext{
Whis seems to correlate with the general uplift to the northwest, as described by $G$. $K$. Gilbert for the area of the Great Lakes.

\$6 Washington township, Ne. qr, of the Ne. qr. nf section 7: 50-60 feet of sand lis between two blue clays, deep in a well that is 210 feet deep. Franklin township. Se. qr. of the Ne. qr. of section 36: There is a gravel at 70 feet with large volume of water. It is beneath yellow and blue clay.
} 
muck. Here the well is at or near the deepest portion of the Aftonian valley. This gives a final local Aftonian relief of forty-three feet, and a valley filling of twenty-five feet, a total of sixty-eight feet, under conditions that mark an erosional valley rather than a constructional depression.

\section{KANSAN STAGE}

Following the Aftonian age $\mathrm{e}^{57}$ there came again an age in which an ice sheet advanced not only over the county but also over the whole of the continent to the north and pushed its way far to the southward into northern Missouri and into Kansas. On melting, the ice left over the Aftonian topography which it had concealed, a deposit of mingled clay, gravel, pebbles and bowlders, known as the Kansan drift, completely mantling the Aftonian topography.

The upper portion of the deposit for more than twenty feet above the typical drift has been so altered by subsequent chemical action, which converted it into the Kansan gumbotil, that this portion will be classed under the Yarmouth stage, and there considered, just as the Nebraskan gumbotil was considered under the Aftonian stage.

The Kansan drift sheet is the conspicuous one to be seen all through the upper portion of the hilly parts of the county. It is this drift which, from thirty to eighty feet below the upland, contains the numerous pebbles and bowlders of all sizes up to three feet in diameter, and of such variety as to attract attention by the exceedingly miscellaneous character of the assemblage. There are granites of many kinds, including especially a dark granite so decomposed by long continued weathering that it crumbles in the hand. Other granites, especially the light colored ones, are of a more resistant character. With these are various quartzites, among which those of a reddish color are most noticeable. Other very resistant rocks are of a dark greenish color and are known as greenstones of various kinıds, generally diorites. With these are pebbles of quartz, chert and schist of various kinds, material from distant sources mingled with fragments of shale and sandstone of more local 
origin, all scattered heterogeneously through a mixture of clay, sand and gravel, everything that an ice sheet could scrape up as it moved over hills and valleys.

The upper, oxidized portion of the typical drift is stained yellowish red. Where this has been subjected to erosion other than weathering the finer material is washed away leaving an accumulation of the more resistant gravel, pebbles and bowlders, such as may be seen along ravines where stream action is vigorous in time of rain. Beneath the filling of the large valleys there are undoubtedly such bowlders and pebbles from both the Kansan and Nebraskan drifts as were too large for transportation by water when the valleys were excavated; but since their excavation the deposition of sediment has concealed the bowlders that are left.

Beneath the zone where weathering has been marked the Kansan drift is progressively darker in color, till deep beneath the surface it is deep blue in color, generally with sand, gravel and bowlders scattered through it, though the mixture is far from uniform. In places it is dense and dark, almost free from grit; in other places it is less dense, and of a more sandy texture.

The largest bowlders noted along the hillsides are chiefly of granite and of red quartzite, of the following dimensions:

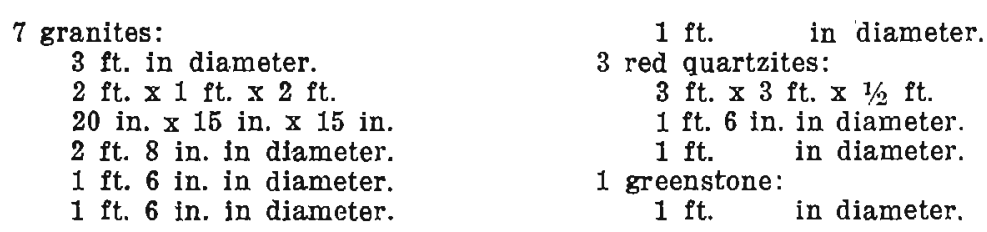

Of these but one, the greenstone, had striations (scratches due to glacial action) still preserved, though polished surfaces and subangular shapes were present.

The following pebble count was made east of Lewis about fifty feet below the upland (southwest quarter of the southeast quarter of ection 12, Oass tơnship) : 

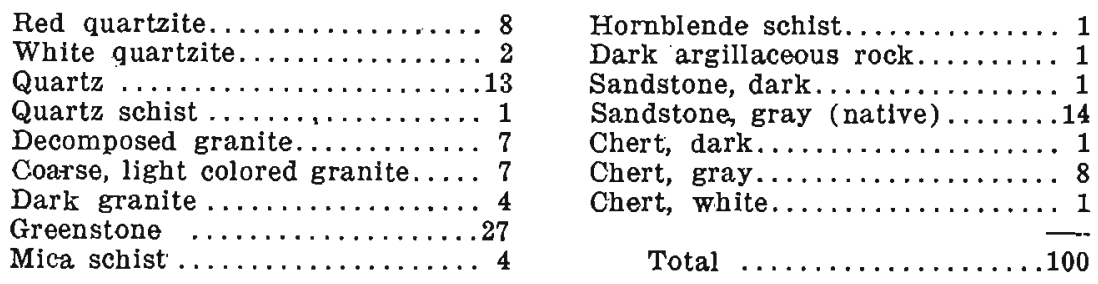

Thickness of the Kansan Drift.-The typical Kansan drift lies between forty feet below the upland, just below the Kansan gumbotil, and the level of the Nebraskan gumbotil, which is about eighty feet below the upland. In such relation the Kansan drift has a thickness of forty feet. It is wanting along all the rivers and large creeks, and along all the smaller ones wherever they have cut down into the Nebraskan gumbotil and drift.

\section{THE YARMOUTH STAGE}

It has long been recognized that the surface of the Kansan drift presented a series of flat topped divides ${ }^{88}$ reaching across southern Iowa from near the Mississippi on the east to the Missouri river on the west. The trend of these divides changes with the direction of stream erosion across the state, so that in the eastern half the divides appear more like a series of steps, while in the western part the divides slope more uniformly toward the west. They clearly mark a dissected Kansan plain; but why should that extent of glacial plain present no evidence of kames, kettles, drumlins and gravel ridges, such as are to be found in younger ground moraines; even within a few miles to the north within our own state? Such features were sought in vain. The uniformly fine material through the upland was loess in the east near the Mississippi river and in the west near the Missouri river. It was also loess in places in the center, and was likened unto loess in other portions. A careful examination of this upland "gumbo", as it was called, revealed that in the divides it was a part of the Kansan drift" into which it graded. Even if composed of surface material from the Kan-

BSee physiographlc descriptions in volumes IV to VIII, Iowa GeologIcal Burvey, chlefly by H. F. Bain; also p. 448 of Vol. VI.

"John L Tilton, "A New SectIon South from De Moines, Iowa," Sclence, Vol. 88, July $25,1913, \mathrm{p}, 133-135$. 
san ice sheet, why did it not contain bowlders such as are found in the oxidized drift so commonly seen by the roadside? This absence of bowlders presented a difficulty that led to emphasis upon the superglacial material that a glacier might carry; and - the various washed sands and gravel along valley: seemed related to the drainage lines formed immediately on the melting of the Kansan ice sheet. ${ }^{60}$ Still there was no explanation for the complete absence of bowlders from the surface. It was at this stage that Professor Kay took up the problem and interpreted the small pebbles found here and there in this deposit as the remnants of former bowlders, the remainder of them having been dissolved away in the course of a long lapse of time in which the surface of the drift was converted into a "gumbotil". ${ }^{61}$ To further test this conclusion a series of analyses of this gumbotil from the surface downward was undertaken by Professor J. N. Pearce, ${ }^{n 2}$ with results revealin'g clearly that the soluble portions, the lime and potash, were dissolved from the upper portion of the drift, to be redeposited lower down. The amount of insoluble material, such as aluminum oxide, is greater in the gumbotil than in the underlying drift. Clearly in the course of a long lapse of time even such quartzite, greenstome and granite bowlders as were in this drift before it was converted into a gumbotil have been dissolved away.

There are places in which bowlders are more abundant than in other places, but no knolls of bowlders have been located rising above the level of the upland. In the eastern and western portions of the state such knolls could easily be concealed by beds of loess; but along the divides, away from struams in southcentral Iowa, regions free from accumulations of loess, no such topographic features are known to exist. The lime in the bowlder clay as it was dissolved out, and the lime and potash from the weathering of the feldspar and mica in the granite, furnished the very alkali material necessary to dissolve the silica, even of quartzite bowlders. A portion of the undissolved silica is still to be found in portions of the gumbotil.

\footnotetext{
wIt was for these various deposits that the name Dallas Deposit was suggested before the significance of the weathering of the drift had been worked out. John L. Tilton, Proceedings of the Iowa Academy of Science, Vol. XX, $p .218$.

"'George F. Kay, "Some Features of the Kansan Drift in Southern Iowa," Bulletin of the Geological Society of America, Vol. 27, pp. 115-117; also "Gumbotil, a New Term in Pleistocene Geology," Science, New Series, Vol. 44, 1916.

arThe analyses are soon to be published.
} 
This explanation of the conversion of the surface deposits of a bowlder clay into a gumbotil emphasizes the length of time required in the Yarmouth stage for the gumbotil to develop before the advance of the next ice sheet, the Illinoian, for the Kansan gumbotil plane is traced eastward beneath the Illinoian drift, and northward beneath the Iowan and the Wisconsin dritt sheets. While the gumbotil is chiefly the result of weathering of drift, the change to a gumbotil is the important feature that. needs emphasis; consequently this deposit is classified as Yarmouth in age. ${ }^{63}$

In Cass county this Kansan gumbotil may be seen in cuts along the edge of the upland, and the gradation may be noted from the surface soil, through the subsurface soil and subsoil to the more distinct drift below, where slumping and creeping have not obscured the gradation, and where loess has not covered the surface. Its lower limit is approximately thirty feet below the level of the upland, down to which level it is a common feature. Low uplands along valleys have been eroded below the horizon of the Kansan gumbotil.

\section{POST-YARMOUTH STAGES}

After the surface of the Kansan drift had been converted into a.gumbotil stream action was hastened by uplift till valleys were finally cut beneath both the Kansan and Nebraskan gumbotils to a depth even a little greater than the present level of the streams (about twenty feet), and an erosional topography was well developed with broad flood plains and gently sloping valley sides. On this surface there are four classes of deposits that claim attention: the sand beneath the river beds, the sand beneath the loess, the loess itself, and the alluvium.

The Sand Beneath the River Beds.-As the drift sheets were eroded the clay was transported away by the rivers, but a part of the sand and gravel, mingled with other sand from eroded Dakota sandstone, was worked along the stream channels and is now beneath the river beds. Sand which was dredged from the river near Griswold was largely of rounded quartz grains, ap-

\footnotetext{
as previously stated the explanation of the Kansan gumbotil was applied to the surface of the Nebraskan drift, leading to the discovery of the Nebraskan gumbo:il plane.
} 
parently derived from Dakota sandstone. Above this is another sand of a fine yellowish character, that is related to the sand found beneath the loess.

The valley filling thus consists of three parts: the lower sand, the fine yellowish sand, and the alluvium.

The Sand Beneath the Loess.-Near Atlantic there is a sheet of yellowish sand of considerable extent. It is well exposed it - the southwestern part of section 28, Pymosa township, in the bluffs along Troublesome creek. Here, five feet above the creek bed and just above Nebraskan bowlder clay, rise bluffs of horizontally stratified sand twelve feet high, brown in general color, gray in places, containing pebbles of light colored quartz, red and gray chert and red quartzite. Wells to the north, northwest and northeast in neighboring sections appear to reach this same sand. In section 33 (northeast quarter of the northeast quarter), Pymosa township, yellow sand appears in abundance by the roadside. Across the valley of Troublesome creek to the south and just east of the Fair Grounds the Rock Island Railroad Company has an extensive excavation for ballast (southeast quarter (f) the southeast quarter of section 4, Grove township). These beds of sand lying exposed in a northwest-southeast direction seem to have been connected formerly, though now separated by the valley of Troublesome creek, and to lie in a valley eroded in Nebraskan drift. They are at a somewhat higher level than the river sand at the city pumping station, and are covered with loess. .

In section 10, Grove township (northeast quarter of the uorthwest quarter), close to the west gate of the Atlantic cemetery, about three feet of a lignt yellowish sand may be seen in the ditch by the roadside. Though somewhat higher than the sand near the railroad, the base of this bed lies at about the levcl of the topmost layers at the pit. Here also the top of the sand is covered by loess. On the opposite side of the city (northeast quarter of the northeast quarter of section 7) lies a similar deposit of sand, at the same level and beneath the loess. Between these two points wells in the city reach a similar bed of sand. In the ravines immediately south of the city Kansan drift ap. pears in the hillsides without sand either above or below it. It 
is thus not between the two drifts, that is, it is not Aftonian, but extends down over the sides of two drifts, and is most abundant in sballow valleys carved in the Nebraskan drift, at too low 9 level for the Aftonian horizon.

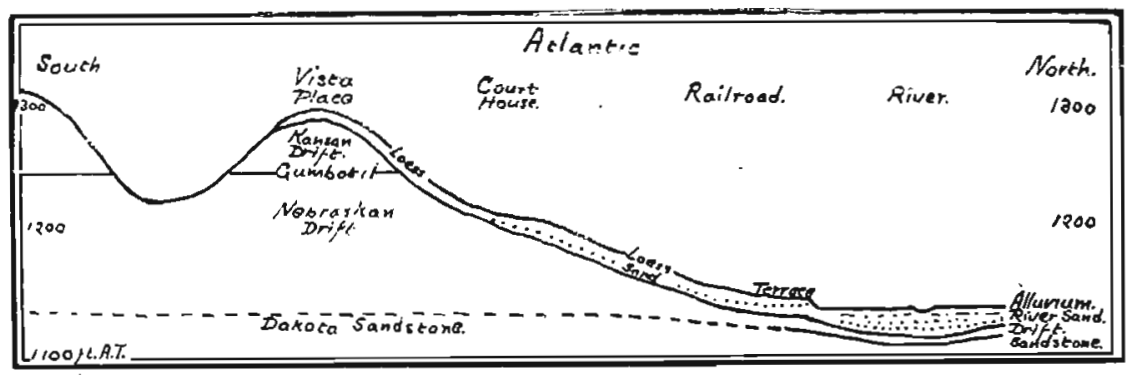

Frg. 32.-Interpretation of relations found at Atlantic, Cass county.

This sand is not river sand, even if it is continuous with that deposit. It appears to have been blown from early river flats out on the side of the post-Yarmouth valleys, and washed into the drainage lines of the region.

The Loess.-Lroess is a wind deposit of fine dustlike material High winds blowing over local hills and river flats and over dry plains farther west sweep into the air from soil of all kinds clouds of dust that settles chiefly along the valleys and on the edge of the upland. In general character the deposits are clayey, though rendered porous by an abundance of minute flakes of quartz whose partly rounded chipped edges and points are evidence of wear as it was blown along. The material contains considerable lime and iron, so that later when it is deposited in beds the upper portions weather further into a light yellowish porous deposit free from lime, while the material two or three feet beneath the surface is less weathered and has a reddish cast due to a larger proportion of the oxide of iron. In deep portions the loess has a grayish tinge of color, where there is considerable lime and where the iron is not oxidized. In many localities the loess is free from shells and especially is this true of the weathered iness, where the shells have been dissolved out. But in some places it contains an abundance of minute and delicate 
shell $s^{e-1}$ generally like those of animals that still live near by and feed in sheltered places upon vegetation at the ronts of grasses and weeds. Often there are found lime concretions which are composed of lime brought in solution from elsewhere, generally in the loess of this region from higher up in the loess.

Loess is most in evidence in the west half of the county. The southwesterly winds that for ages have blown up the valleys of Nishnabotna river and Indian creek have left deposits at many places where deposition has been favored and erosion prevented. At the railroad station at Marne is the most typical bed to be found in the county. The part that is exposed is twenty-seven

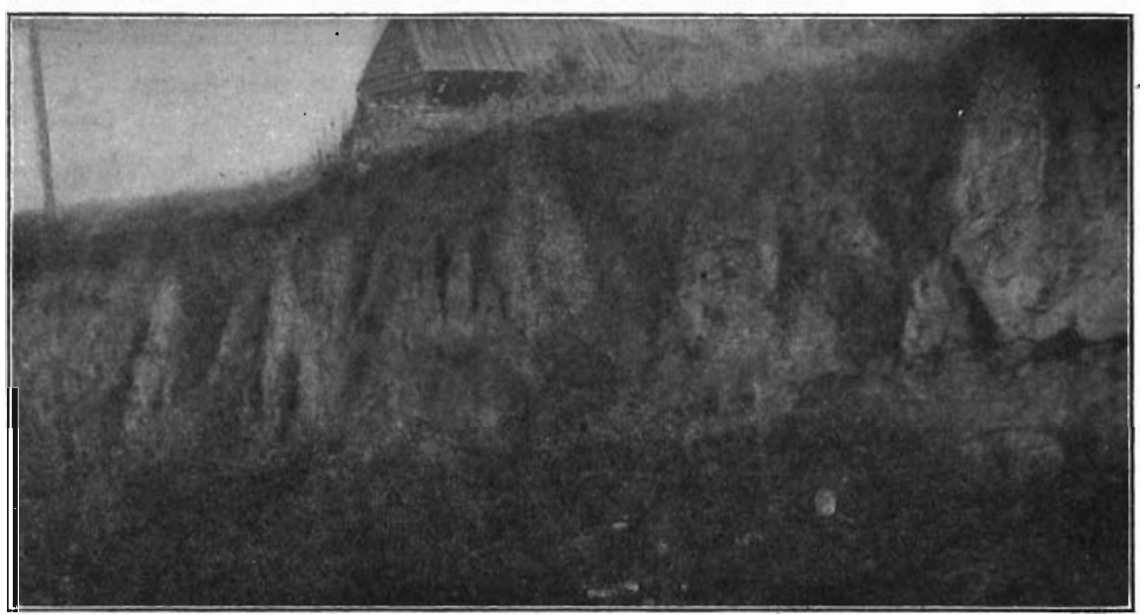

Fig. 33.-The bed of loess near the railroad station at Marne, Cass county.

feet thick, laminated, fossiliferous, and bearing concretions. It possesses the mealy character, the vertical cleavage, and the porosity common to loess found in the bluffs along Missouri river. The upper eight or ten feet is of a brown color; that in the lower, unoxidized portion is of a gray color.

A mile west of Marne the upper eight feet of the railroad cut consists of brownish weathered loess; which is here free from lamination and from lime concretions and shells. So, too, in

\footnotetext{
"For a discussion of loess fossils see B. Shimek, "The Significance of Pleistocene Mollusks," Science, $N$. S. Vol. 37, April 4, 1913, pp. 501-509; "Alluvial Fossils and Modern Drifted Shells," Supplement to the address of the chairman of section F, Geology, American Association for the Advancement of Science, Cleveland, Ohio. 1912; "Geology of Harrison and Monona Counties," Iowa Geological Survey, Vol. XX, 1909, pp. $395-8$.
} 
the cut between Indian creek and the west county line, the uppermost portions are composed of loess, which is now mostly grassed over. A mile and a half east of Marne, at the highest point in the divide, a gray loess is found for six feet below the grass. It is free from lamination, from fossils and from concretions, and is sandy. On lower ground north and west the sides of a gully are distinctly not loess.

At Atlantic the pit ten feet deep for the base of the soldiers' monument was dug in loess that showed lamination up to four feet from the soil. It here contains no fossils and no concretions. The excavation for the basement of the new high school building is in loess of the same character. At Vista Place loess caps the upland; only toward the bottom of excavations for the roadway does the weathered Kansan drift with a few pebbles appear. At the clay pit west of town the deposit is a loess, though very clayey and free from fossils and concretions. The lamination noted seemed due to slumping. So, too, at Lewis the clay pit is in a gray loess banked in on the west side of the valley and rising ten feet above the second bottom. This loess is noted along the western slope of the Nishnabotna, and along the highest ground to the east, as in section 24 of Cass township (southeast quarter of the southeast quarter) and section 26 (southwest quarter of the southwest quarter); in section 6 of Beargrove township (northwest quarter of the northwest quarter), section 7 (southeast quarter of the southeast quarter) and section 27 (southeast quarter of the southeast quarter); section 11 of Pleasant township (southwest quarter of the southwest quarter) and section 13 (northwest quarter of the northwest quarter); section 18 of Noble township (northeast quarter of the northwest quarter) and section 27 (southeast quarter of the southwest quarter). On the other hand it is not recognized as a distinct loess deposit on the highest ground in the northwestern part of Pymosa township, nor in the various cuts from Atlantic along the railroad to the east county line, nor in the divides in the eastern half of the county.

In general the loess is banked in on the east side of the valleys of Indian creek and of the Nishnabotna as far as Atlantic, and against the highest ground half way across the county, espe- 
cially the highest ground facing the west and southwest. From Atlantic northward along the river valley the west side of the valley is favored with loess because of the turn in the valley by which the west side is brought into the line of air movement of the prevailing southwesterly winds up the valley. The same is true along the northern side of Turkey creek in the lower part of its course; but in the northeastern part of the county the eastern side of the valley is more favored by deposition. ' Loess is abundant south and southwest of Adair. Along the west branch of the Nodaway and its tributaries the deposition of loess is not so pronounced.

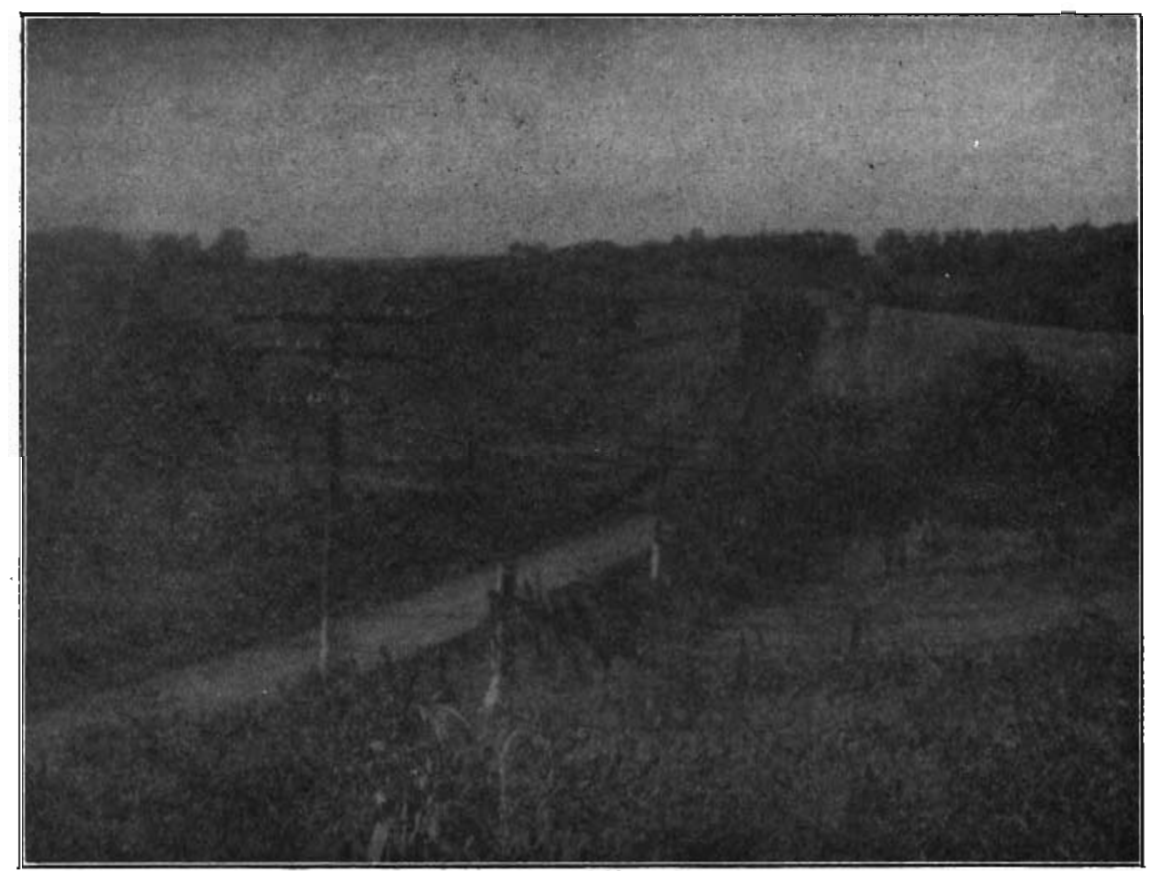

Fig. 34.--Where the loessial topography ends and the erosional topography in the upland begins. View southeast from Vista Place, Atlantic, Cass county.

Along ravines everywhere, except where they emerge near low ground close to the Nishnabotna, loess has been eroded away if it was ever deposited.

It is possible that on the high ground to the east of Troublesome creek and to the southeast of Turkey creek there are beds concealed in favored places, and that loess forms an inconspic- 
uous portion of the soil. As traced from one divide to another east from the creeks the loessial characteristics became less distinet, and in the place of loess was noted a deposit of indefinite character that may result from gumbotil or from a thin loesslike deposit, the two forming black soils that are much alike.

From Atlantic southwest along the east side of the Nishnabotna the loess seen was completely leached of its lime through the action of ground water. This, with the loss of silica and iron carried away in solution, would account for the especially clayey character where the action of ground water has been pronounced.

The Alluvium.-A considerable area of bottom land along Nishnabotna river and Indian, Troublesome and Turkey creeks, has been frequently inundated by high water. The deposit laid down in time of flood is a fine dark colored laminated clayey silt. There are numerous oxbows along these streams, and places that are scoured by concentrated flow at high water. In such places the water stands for considerable time after the floods are over, till in the course of years they are gradually filled by a dark, fine clay of uniform composition.

The Terrace.-The terrace is composed in places of Nebraskan. drift left uneroded and in places of a dense dark deposit washed in at a former time when the river flowed at a higher level than at present. Loess is found also in places on the terrace, and also in places banked in against it as previously described.

Sequence of Post-Yarmouth Events.-From the beginning of the uplift that hastened the erosion of valleys in the Kansan and Nebraskan drifts till they reached a depth of twenty feet below the present level of the streams, until the present time there is in Cass county no distinctly separate effect traceable to the existence of Illinoian, Iowan and Wisconsin drift sheets, nor to the presence of Sangamon and Peorian interglacial intervals, and no separate effect traceable to changes in elevation ${ }^{85}$ either

${ }^{\circ} \mathrm{C}$. H. Gordon, Buried Rlver Channels in 'Southeastern Iowa; Iowa Geological Survey, Vol. TII, p. 239,1893 .

Charles R. Keyes, Geology of Lee County; Iowa Geological Survey, Vol. III, Plates 27 and $28,1893$.

J. A. Udden, Geology of Muscatine County ; Iowa Geological Survey, Vol. IX, Plate 7. p. 332,1899 .

W. H. Norton, Geology of Scott County ; Iowa Geologlcal Survey, Vol. IX, pp. 413418,1899 .

Frank Leverett, The Illinols Glacial Lobe; Monograph XXXVIII, U. S. G. S., Chap. 12, 1899 .

J. Ernest Carman, The Mississippl Valley between Savanna and Davenport; Illi-

nois Geological Survey, Bull. 13, pp. 57-78, 1909 . the Iowa Áademy of Science, Vol. XXI, for 1914, especially pages 177-179. 
to the north or to the south of Cass county. All such effects are lost as minor details in the general trend of events, all merged into one long-continued time of erosion. It is to a time preceding the silting up of the valleys, perhaps to the early part of it, that it seems necessary to refer the deposition of sand blown out over the low ground of Nebraskan drift, and, following this, the beginning of the deposition of a considerable body of loess out over the sand. A portion of the loess is undoubtedly related to thick beds of loess in central and eastern parts of the stare, which beds are found to be Peorian in age. Deposition of loess in some places and erosion of it in other places is judged to have continued with varying rapidity eren up to the present time. On the melting of the Wisconsin ice sheet there was an immediate and pronounced effect, traceable in the terrace.

The terrace along the Nishnabotna and the Nodaway, and along streams of southwestern Iowa, is continuous with the terrace along Missouri river, which in turn is traced to the same causes that produced the terrace deposits along Mississippi, Des Moines and Middle rivers: ${ }^{: 8}$ namely, the flooding of the valleys on the melting of the Wisconsin ice sheet, and the partial filling of the valleys with sediment. The great volume of water that sought an outlet southward through Missouri river into the Mississippi and thence to the gulf is well attested by the river gravels, terraces and deltas through which the present streams of comparatively insignificant size have since cut their trenches. ${ }^{\text {e? }}$ The backwater thus produced in the tributaries led to the silting up of their channels, such as those in Cass county, to the level of the present terrace.

In Cass county the drainage has a peculiar relation to drainage from the Wisconsin ice, and affords a chance to test the conclusion above stated. Neither the west branch of Nodaway river nor any of its tributaries, which drain the southeastern half of the county, rises near the area of the Wisconsin drift, drainage now, and probably formerly, being cut off on the northeast by Raccoon, North and Middle rivers with their tributaries. Conditions are different for the East Nishnabotna which flows

\footnotetext{
${ }^{8} \mathrm{~J}$ John L Tilton The Age of the Terrace South of Des Moines, Iowa; Proceedings of the Iowa Academy of Science, Vol. XXII, for 1915, pp. 233-236.

oTThe various folios of the Geologic Atlas of the U. S. Geological Survey coverin parts of eastern North and South Dakota are very significant in this regard.
} 
through the western part of the county. This stream rises not far from the margin of the Wisconsin drift. Though Brushy Fork in Carroll county now cuts off from this river the drainage from the area of the Wisconsin drift, the Nishnabotna may formerly have secured part of its sediment from the outwash area southwest of the Wisconsin drift. While the silting up of the Nishnabotna channel would lead to silting up along Indian creek, it would not lead to the silting up found in the Nodaway valley. To accomplish this Missouri river itself must be affected. It thus appears that a common cause was operative affecting this whole region.

After the melting of the ice the streams diminished in volume to their present size, and assumed the new task imposed upon them of removing the clay, silt and sand that clogged their courses and of establishing a new grade below the former terrace level. Whether this renewal of erosive stream action was due in part to a slight uplift, or wholly to a lessening of the load carried by streams, is not clear from data here obtainable. The task is now accomplished to such an extent that we find the streams flowing on gradients fairly well established; but the difficulty of accomplishing the task is still evident in the presence of numerous bayous and the marshy ground along the rivers, and in the cutting as well as filling that has resulted in the present flood plain eight feet below the level of the old flood plain. Parts of the old flood plain are now left as a terrace through which the water from the various ravines in the upland has trenched its way. Ridges from the terrace now reach out into this bottom land in places, while along the eastern side of Nishnabotna loess is still banked against the terrace.

Recent natural changes are insignificant in comparison with those above described. The most pronounced is the renewal of erosion along the edge of the upland, less marked here than farther east, which is traceable to effects of cultivation of the soil, and particularly to the destruction of the old blue-stem prairie grass with its long roots. ${ }^{68}$ Along ravines deposits are forming in some places and disappearing in others, under the changing influences of the hand of man. Along the river bottoms

${ }^{69} \mathrm{John}$ L. Tilton, Pleistocene Deposits of Warren County, Iowa, pp. 39-40. 
the streams occasionally cut horizontally, and in time of flood scour and fill. They have reached their grade, and show no present effects of changing elevation. The wind sweeps the dust up the valleys, adding an increment to the loess beds that during the year is inappreciable, though in the course of many years it is considerable. The chief factor now influencing change is Man.

\section{ECONOMIC GEOLOGY}

Soils

The distribution of the Pleistocene deposits just described is the key to the character of the soil.

Loess. - On the upland bordering the east side of the river valleys (chiefly the west side north of Atlantic and along Turkey creek as previously stated) and down the western slope of the upland, is the yellow loess, thin in the upland, and thicker on gentle hill slopes, with little distinction between soil and subsoil, but with the upper two feet darkened by humus that has been forming for ages. This soil is naturally well drained because of its porosity, while this property, due to the loose arrangement (structure) of the fine quartz and clay, also permits water to rise by capillarity from below to the roots of the plants. It is only when stirred while there is water on it that the clayey portion settles forming an impervious stratum over the bottom of the pool. Such land is the richest corn land in Iowa. This loess soil is the Marshall silt loam of the government classification of soils.

Along the western edges of the upland lies the Kansan gumbotil beneath the loess, and close enough to form a subsoil where the loess is thin. The leaching of ages has removed the lime formerly a part of it, and has removed other portions, not only the more readily soluble portions of a bowlder clay but even much of the silica from decaying pebbles and bowlders that may for. merly have been present, leaving the remainder more clayey than before. Concealed beneath the loess it cannot readily dry out and thus serves as somewhat of a reservoir of moisture and also as a base to the more porous loess above. The slight change in the character of the subsoil from loess to gumbotil is not sufficient to affect the character of the soil. 
Loess is found also in beds at lower levels, especially in the terrace east of the Nishnabotna. Here it is the same class of soil as in the upland, but the surface of the loess lies nearer the general level of the water table.

Gumbotil:-Along the upland where the loess is thin, especially along the upper slopes on the western sides of the valleys, the Kansan gumbotil forms a soil much like that formed by the loess, but with a subsoil more clayey than loess. The change in color from a light yellowish to a yellowish red is due to the increase of iron from the surface down into the deeper portions of the subsoil; with this change there is an increase in lime and potash. In classification this soil has been included in the southern Iowa Loess. ${ }^{\circ 0}$ By the United States Bureau of Soils it is called the Putnam silt loam ${ }^{70}$ and at times the Shelby silt loam. It is also called the Marshall silt loam. ${ }^{71}$ Mr. Coffee in discussing this soil recognizes its clayey character as not like that of a true loess.

When the gumbotil is charged with humus it makes a rich porous soil second only to that of loess, but the gradation downward into a distinct weathered bowlder clay reveals its true relation. The clay beneath serves as an imperfect water carrier to retain moisture for the plants above, and serves also as a reservoir of mineral matter that can by capillarity reach the plants above in solution. The treatment of this rich soil of gumbotil is readily mastered. The roads composed of it must be dragged while the gumbotil is drying, and corn planted in it must be cultivated after the soil is too.dry to.stick and not dry enough to cake. By cultivation rapid evaporation of moisture is prevented, while capillarity still brings up to the roots the moisture needed.

The Nebraskan gumbotil, which is found about eighty feet below the upland, is the same kind of soil material as the Kansan gumbotil, and deserves to be classed with it.

\footnotetext{
${ }^{80} \mathrm{~W}$. H. Stevenson, "The Princlpal Soil Areas of Iowa," Bull. 82, p. 378, 1911, Agricultural Experiment Station. Solls Section. Ames, Iowa.

"George Nelson Coffee, "A Study of the Soils of the United States," Bureau of sioils, Bull. No. 85, p. 51,1913 .

"Jay A. Bonsteel, "Important American Soils," Yearbook of the Department of Agriculture, 1911, p. 225. In "Soil Survey of Pottawattamie County, Iowa," U. S". Bureau of Soils, 1916, pp. 15-16. Marshall silt loam is said to be derived from Missouri loess, but seems to include the gumbotil, for whioh there is no special designation. 
Drift Soil.-In places along the hillsides the bowlder bearing portion of the drift lies close to the surface, the pebblès in places showing in the thin soil along the slopes. This type of soil in Cass county is not so abundant as it is farther east in southcentral Iowa where there is no loess. Where these patches of soil-are so inconspicuous as not to interfere, with cultivation the soil may still be considered a Putnam silt loam, though thin. Where the surface is too rugged for cultivation, and the soil now as before the advent of the white man is given over to timber, this light colored timbered soil is classed in the Miami series of soils.

Collwial Soil.-from loess, gumbotil and drift. Along the bases of gentle slopes in ravines a thick soil has gradually accumulated due to the creep of soil from the hillsides as the material alternately froze and thawed, and was alternately water soaked and dry. At times surface erosion supplied material that rain washed down the slope. All such deposits along the valleys and ravines are classed as colluvial deposits. Inasmuch as they partake of the general character of material in the upland, and are equally well drained, they also are classed as Putnam silt loam where the gumbotil is the chief source, and as colluvial Marshall silt loam where loess is the chief constituent. This deposit is to be distinguished from the beds of loess that are banked against the eastern valley sides along Nishnabotna river and Indian and Turkey creeks, which are of true loess undisturbed.

Alluvial Soil.-The terrace along the rivers is in places more sandy than the colluvial deposits, and in places more clayey, consisting of material brought down by the river when it flowed at this higher level, mingled with material washed from slopes nearer at hand. The terrace is high enough now to be well drained. Thus drained and aerated the material forms a soil that seems a continuation of the colluvial soil. It is recognized as an alluvial silt loam from dark colored prairie soils. The terrace generally has water bearing sand fifteen to twenty feet beneath its surface, giving an ever present supply of moisture near at hand. This soil is to be distinguished from loess banked in against it. 
Near the stream the flood plain receives, especially in the spring time, the present alluvial deposits of the stream. These form a slightly higher deposit close to the stream where the coarsest deposits are laid down, building up the natural levee. Back from the natural levee the low ground has favored the formation of swamp soils, especially in bayous, or old stream channels. Even this swamp soil becomes good soil for cultivation when properly drained. The straightening of the courses of Indian creek and of the Nishnabotna and the use of lateral ditches and tiling here and there to drain low places, is not only preventing floods but also opening to cultivation thousands of acres that prior to the drainage of these low places were unfit for cultivation.

Old soils from weathered Dakota sandstone and from Missouri limestone and shale are so concealed by the drift that they do not deserve consideration in this connection. It is only occasionally that over a few square feet their products are a considerable constituent in the soil.

CROPS.

In the past twenty-seven years corm ${ }^{i 2}$ has averaged 32.3 bushels per acre, the amount per year varying with the character of the season. The maximum of 38 bushels per acre was obtained in 1916. Wheat has averaged 15.8 bushels per acre, the variations between spring and fall wheat in a measure off-setting each other, the maximum reaching 23 bushels per acre. Oats has averaged 27.7 bushels per acre with a maximum of 47 bushels. Barley has averaged 25.4 bushels with a maximum of 34 . Potatoes have averaged 75.6 bushels, with a maximum of 177 bushels. Rye has averaged 21.3 bushels in the past fourteen years, with a maximum of 45 bushels. Tame and wild hay together have averaged 1.5 tons per acre. In the past few years alfalfa has been grown with an average of 3.5 to 4 tons per acre.

There is no record of the amount of yield of the different types of soil. With a continuation and an extension of the modern careful selection of seed corn and care in the selection of other grain for seed the average yield will undoubtedly increase. This average will be still further increased by the tiling of wet

${ }^{72}$ From the Anmual Reports of the Iowa Weather and Crop Service. 
places and by the drainage of the bottom land, thus saving the acreage in places that in other years has been too wet to mature a crop. The chief factors determining the yield are variation in precipitation combined with duration. of high temperature, which in a measure operate together, the highest temperature occurring when precipitation is least. Already the'farmers not only seek to maintain a good average yield by planting fields that give their best vields under different conditions, one when the season is wet and another when the season is dry, but they study the most suitable methods for cultivation under the different conditions. Even with this care the effects of drought with long periods of intense heat cannot be fully offset. Fortunately, however, such instances as the drought of 1894 and of 1910 are extremely rare, and the high temperature of 1901 is unusual. In 1901 potatoes and corn were the only crops affected noticeably. Generally, and almost without exception, the precipitation occurs in sufficient abundance during the growing months to meet the needs of the crops.

\section{Meteorology}

The location of Cass county upon the western side of the "Missouri divide", places it in Section 52 of the Weather

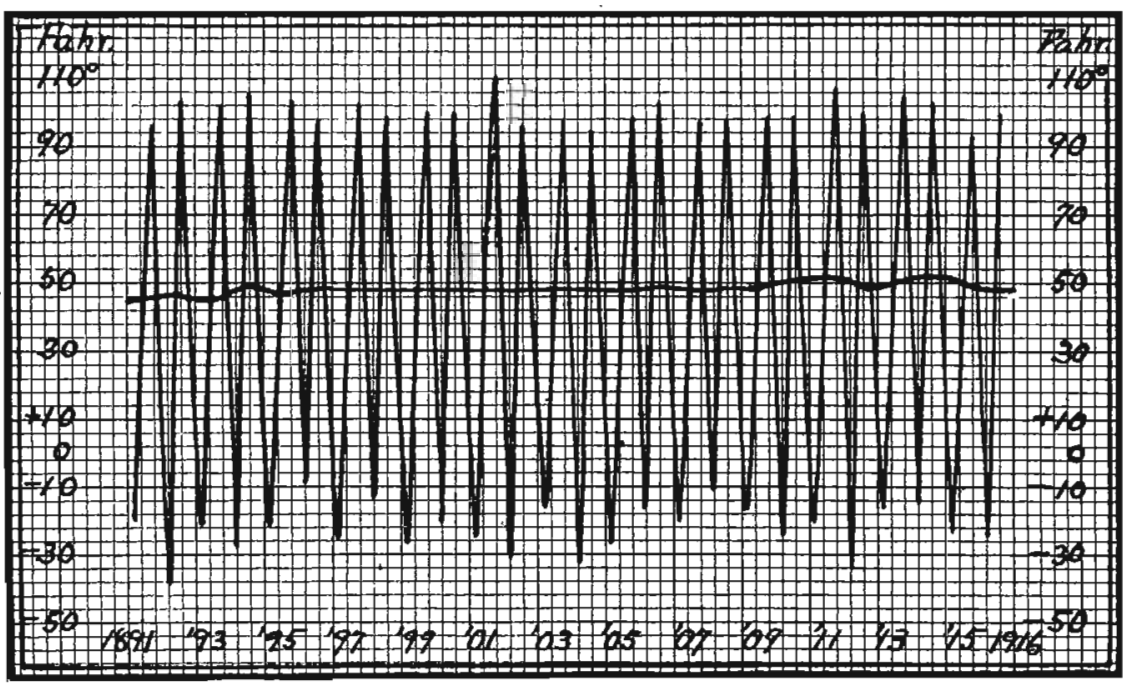

Frg. 35.-Diagram of maximum, minimum and mean temperatures for Atlantic, Cass county, 1891 to 1916 . 
Bureau, United States Department of Agriculture; it is also classed in the "Southern Division" in the reports of the State of Iowa. From the records of J. W. Love and of T. H. Whitney of Atlantic, which cover the years since 1890, the mean annual temperature is found to be $48.3^{\circ} \mathrm{Fahr}$., ranging from an average maximum of $99.8^{\circ}$ for these years to an average minimum of minus $12.2^{\circ}$ for the same length of time. The variations are best given in the form of a diagram.

The mean annual precipitation is 31.87 inches, distributed by months as follows:
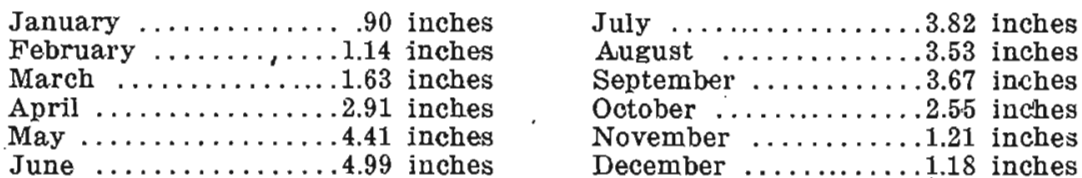

In sixteen years the direction of the wind has averaged Nw. 5 , Sw. 6, S. 4, Se. 1. In the same number of years there has been an average of ninety days per year with one one-hundredth of an inch or more of precipitation. In character the days have averaged as follows per year: clear, 109; partly cloudy, 108; cloudy, 148.

RECORD OF PRECIPITATION78 IN INCHES AT ATLANTIC, IOWA.

ALTITUDE 1164 FEET ABOVE SEA LEVEL.

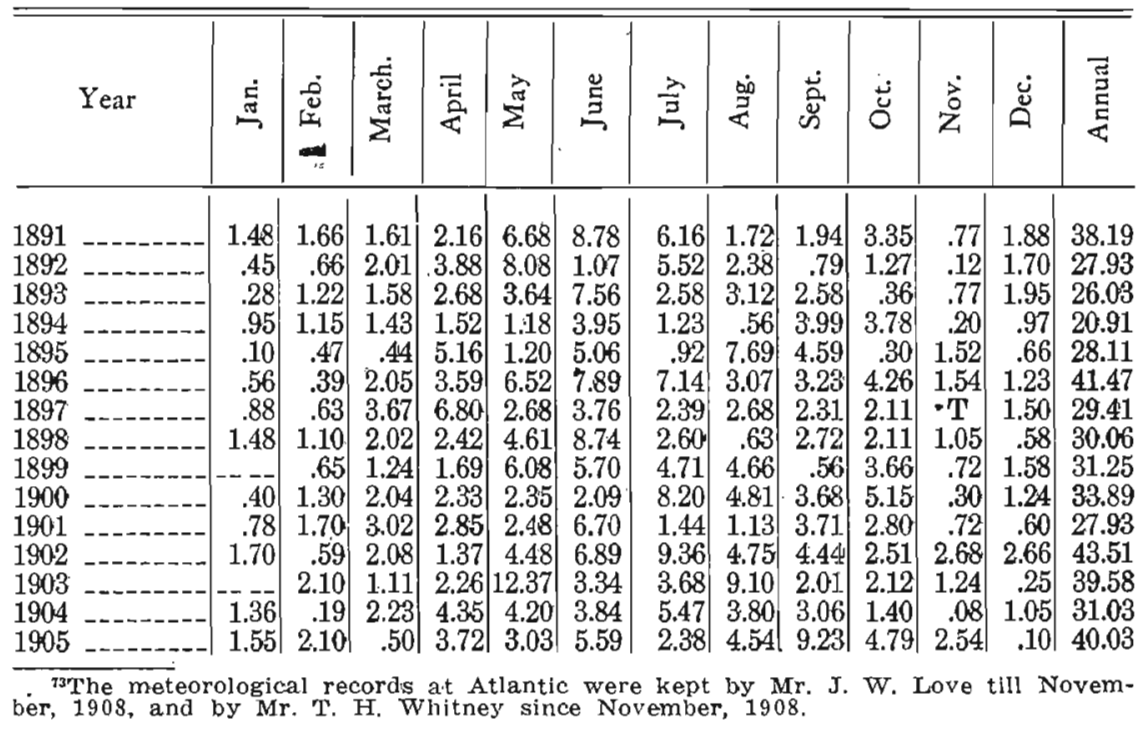


RECORD OF PRECIPITATION. (Continued)

\begin{tabular}{|c|c|c|c|c|c|c|c|c|c|c|c|c|c|}
\hline Year & 㥯 & 这 & 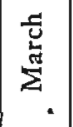 & 怘 & 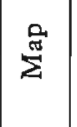 & 总 & $\frac{2}{3}$ & 这 & 莕 & ப் & $\dot{z}$ & $\dot{\tilde{Q}}$ & 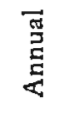 \\
\hline 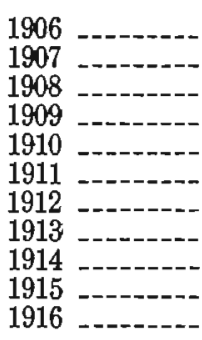 & $\begin{array}{r}.80 \\
.10 \\
.22 \\
1.90 \\
1.17 \\
35 \\
.52 \\
.89 \\
.86 \\
2.13 \\
2.54\end{array}$ & $\begin{array}{r}.99 \\
.98 \\
1.60 \\
1.40 \\
.28 \\
2.69 \\
1.74 \\
.69 \\
.78 \\
2.15 \\
.53\end{array}$ & $\begin{array}{r}1.97 \\
.77 \\
.85 \\
.97 \\
--.8 \\
.86 \\
2.61 \\
3.35 \\
2.17 \\
1.29 \\
.47\end{array}$ & $\begin{array}{r}4.34 \\
.94 \\
.93 \\
3.63 \\
.30 \\
3.40 \\
3.59 \\
3.29 \\
4.84 \\
1.53 \\
2.22\end{array}$ & $\begin{array}{l}2.65 \\
2.19 \\
8.80 \\
3.43 \\
3.37 \\
4.32 \\
.72 \\
6.82 \\
1.28 \\
8.27 \\
3.20\end{array}$ & $\begin{array}{l}5.87 \\
5.13 \\
7.22 \\
9.08 \\
2.71 \\
.31 \\
3.38 \\
3.10 \\
6.60 \\
3.01 \\
2.51\end{array}$ & $\begin{array}{r}3.91 \\
5.93 \\
2.23 \\
6.00 \\
.82 \\
.89 \\
1.82 \\
.49 \\
1.20 \\
9.58 \\
2.65\end{array}$ & $\begin{array}{r}2.53 \\
2.56 \\
3.57 \\
.44 \\
11.22 \\
3.95 \\
2.88 \\
1.49 \\
2.71 \\
3.88 \\
1.81 \\
\mid\end{array}$ & $\begin{array}{r}6.53 \\
3.00 \\
.73 \\
6.03 \\
2.95 \\
2.14 \\
6.05 \\
3.75 \\
6.49 \\
3.65 \\
5.31\end{array}$ & $\begin{array}{l}1.15 \\
1.77 \\
3.96 \\
2.90 \\
1.15 \\
1.85 \\
4.38 \\
1.78 \\
4.46 \\
1.49 \\
1.43\end{array}$ & $\begin{array}{r}1.53 \\
.88 \\
.29 \\
8.66 \\
.39 \\
.53 \\
.40 \\
1.28 \\
.16 \\
1.54 \\
1.61\end{array}$ & \begin{tabular}{r|}
1.30 \\
.26 \\
.46 \\
1.94 \\
.16 \\
3.40 \\
.36 \\
1.53 \\
1.40 \\
1.02 \\
.96
\end{tabular} & $\begin{array}{l}33.57 \\
24.51 \\
30.86 \\
46.58 \\
24.52 \\
24.69 \\
28.45 \\
28.46 \\
32.95 \\
39.54 \\
25.24\end{array}$ \\
\hline eans & .90 & 1.14 & 1.63 & 2.91 & 4.41 & 4.99 & 3.82 & 3.53 & 3.67 & 2.55 & 1.21 & 1.18 & 31.87 \\
\hline
\end{tabular}

RECORD OF PRECIPITATION" IN INCHES AT CUMBERLAND, IOWA.

ALTITUDE 1228 FEET ABOVE SEA LEVEL.

\begin{tabular}{|c|c|c|c|c|c|c|c|c|c|c|c|c|c|}
\hline Year & 莺 & 造 & $\begin{array}{l}\text { 点 } \\
\text { 芴 }\end{array}$ & 㤩 & 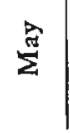 & 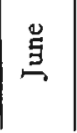 & 롤 & $\ddot{z}$ & 램 & ــ & $\frac{\text { 宫 }}{\text { 蕰 }}$ & \&્d & 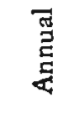 \\
\hline $\begin{array}{l}1900 \\
1901 \\
1902 \\
1903 \\
1904 \\
1905 \\
190 \\
1906 \\
1907 \\
1908 \\
1909 \\
1910 \\
1911 \\
1912 \\
19- \\
-\end{array}$ & $\begin{array}{c}.10 \\
.40 \\
1.10 \\
\mathrm{~T} \\
2.10 \\
1.00 \\
1.40 \\
.73 \\
.80 \\
2.12 \\
.90 \\
.40 \\
.35 \\
.90 \\
.61 \\
.76 \\
1.27\end{array}$ & $\begin{array}{r}.73 \\
1.50 \\
.21 \\
1.00 \\
.10 \\
2.25 \\
.50 \\
1.11 \\
1.80 \\
.85 \\
.60 \\
2.64 \\
1.70 \\
.70 \\
.70 \\
1.45 \\
.60\end{array}$ & $\begin{array}{r}2.12 \\
1.55 \\
4.33 \\
1.10 \\
3.20 \\
.90 \\
2.62 \\
.38 \\
2.31 \\
1.10\end{array}$ & $\begin{array}{r}1.91 \\
2.22 \\
.51 \\
1.65 \\
4.10 \\
3.52 \\
2.40 \\
1.24 \\
.77 \\
5.36 \\
.20 \\
3.65 \\
3.15 \\
2.10 \\
3.11 \\
1.98 \\
2.04\end{array}$ & $\begin{array}{r}2.78 \\
2.33 \\
2.26 \\
8.27 \\
3.42 \\
4.94 \\
1.73 \\
2.46 \\
12.00 \\
3.59 \\
2.73 \\
2.86 \\
1.29 \\
7.61 \\
1.10 \\
8.44 \\
3.18\end{array}$ & $\begin{array}{l}1.89 \\
5.14 \\
6.06 \\
2.96 \\
3.71 \\
5.81 \\
5.67 \\
6.28 \\
8.28 \\
6.92 \\
1.39 \\
.27 \\
3.54 \\
4.12 \\
3.56 \\
4.26 \\
2.58\end{array}$ & \begin{tabular}{|r}
4.33 \\
1.39 \\
8.99 \\
6.69 \\
4.71 \\
4.02 \\
3.17 \\
10.76 \\
4.42 \\
4.73 \\
2.50 \\
.63 \\
1.57 \\
.11 \\
1.10 \\
7.70 \\
1.41
\end{tabular} & $\begin{array}{c}3.59 \\
.71 \\
5.36 \\
9.32 \\
3.25 \\
3.73 \\
1.86 \\
1.87 \\
6.19 \\
.50 \\
7.10 \\
3.93 \\
3.61 \\
2.25 \\
2.50 \\
2.58 \\
1.71\end{array}$ & \begin{tabular}{|l}
4.63 \\
2.87 \\
5.46 \\
1.70 \\
2.03 \\
8.22 \\
3.33 \\
3.38 \\
1.52 \\
4.14 \\
5.00 \\
3.65 \\
4.94 \\
4.71 \\
5.07 \\
3.28 \\
2.47
\end{tabular} & $\begin{array}{l}4.40 \\
2.46 \\
3.23 \\
2.15 \\
1.32 \\
2.85 \\
1.10 \\
2.81 \\
4.14 \\
4.70 \\
1.56 \\
.77 \\
2.90 \\
6.27 \\
2.51 \\
.89 \\
.97\end{array}$ & $\begin{array}{r}.20 \\
1.24 \\
1.37 \\
.78 \\
-2.31 \\
1.32 \\
1.42 \\
.76 \\
3.36 \\
1.03 \\
.51 \\
.42 \\
.87 \\
--.62 \\
.62 \\
2.13\end{array}$ & $\begin{array}{r}.30 \\
.80 \\
1.80 \\
.20 \\
1.20 \\
.04 \\
2.00 \\
1.37 \\
.08 \\
1.80 \\
.20 \\
3.45 \\
.13 \\
1.71 \\
.80 \\
.11 \\
.91\end{array}$ & $\begin{array}{l}26.98 \\
22.61 \\
40.68 \\
35.82 \\
29.14 \\
39.59 \\
27.10 \\
33.81 \\
43.07 \\
39.17 \\
23.21 \\
23.06 \\
26.10 \\
33.32 \\
23.34 \\
32.47 \\
19.57\end{array}$ \\
\hline eans & .88 & $\mid 1.08$ & 1.69 & 2.35 & 4.18 & 4.26 & 4.01 & 3.53 & 3.91 & 2.65 & \begin{tabular}{|l|l}
$\mid$ & 1.08
\end{tabular} & .99 & 30.53 \\
\hline
\end{tabular}

From these tables the precipitation during the growing months is found to be as follows:

\footnotetext{
"The meteorological records at Cumberland have been kept by $\mathrm{Mr}$. J. H. Reppert.
} 


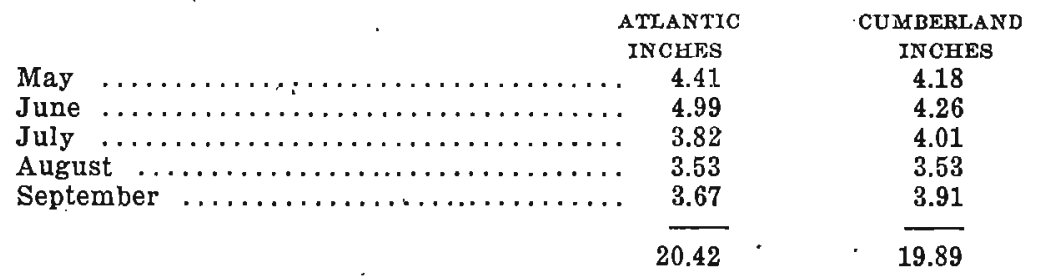

'The dates of the last killing frost in the spring and the first killing frost in the fall are as follows, for Atlantic:

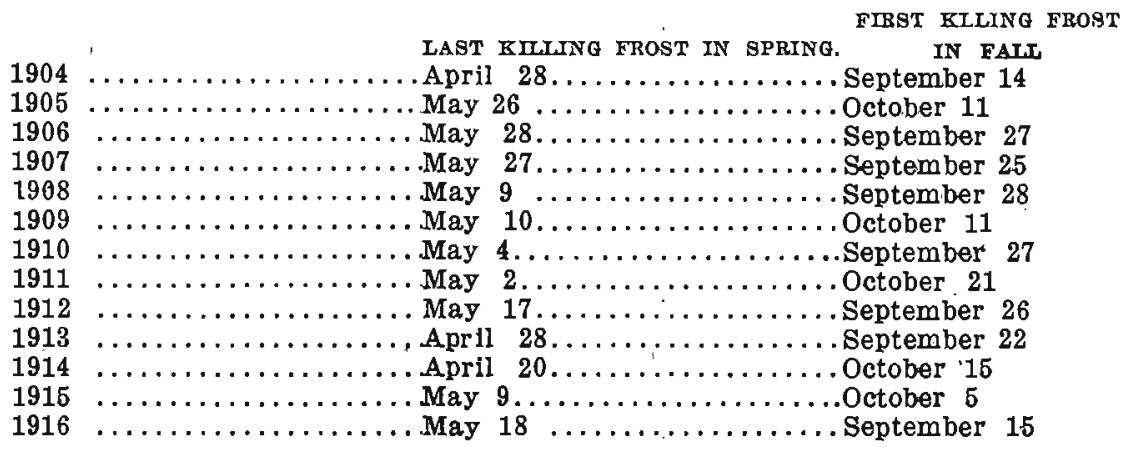

The earliest date of the last freezing temperature in the spring is April 20 (1914), and the latest date is May 28 (1906). The earliest date of freezing temperature in the fall is Septem. ber 14 (1904); the latest date is October 15 (1914).

\section{Native Flora and Fauna}

Here as elsewhere in southwestern Iowa the native timber is confined to ravines and river valleys, where the ground is pro. tected from the intense rays of the summer sun and the dry southwest winds. The groves that now beautify the homes on the uplands and add comfort there are all planted by man. Here the sofit maple, because of its rapid growth, is a favorite for groves, while the red and white elms, the box elder, sometimes the cottonwood, and occasionally the spruce, are used for ornament and individual shade. The native grasses are largely replaced by blue grass, timothy and clover on the upland, but on the low ground a wild hay is harvested in about the same quantities as the tame hay. In out-of-the-way places, along the shady hillsides and along roadways may still be seen the native flora; but it is undergoing a rapid change because of cultivation of the 
soil. This fact is emphasized in the appended list of some of the plants of Cass county. As the boggy ground along the larger streams is now drained the habitat of the cattail flag, water leaf and arrow leaf is also restricted in area.

The large forms of the wild fauna that frequented these valleys before the advent of the white man are now completely gone, except the pair of deer protected in the wilds of a small park of native plants preserved for years through the foresight and love of nature of Mr. F. C. Pellett and Mr. T. H. Whitney. Of the smaller forms the fox squirrel still peers through the branches, and the ground squirrel scurries to his hole. Amid the trees and brush the catbird, thrasher, oreole, wren, song sparrow, robin and bluebird contribute their abundant labor to the welfare of man and add the beauty of their song. The everpresent crow rivals the noisy blue jay and pugnaceous English sparrow for supremacy in the feathered tribe. The busy flicker, red headed and downy woodpeckers search for their hidden prey, the barn swallow, martin and chimney swift flit about, while in the quiet shades by the river the kingfisher and heron patiently wait their chance. The quail, protected by the game laws, is the last of the important game birds of the early days, excepting those that in migration pause on their way morth or south.

SOME OF THE COMMON PLANTS OF CASS COUNTY, IOWA. ${ }^{75}$

For the following list of plants I am almost entirely indebted to Miss Besse S. Tilton, teacher of science at the Atlantic High School, 1913 to 1917, and to Mr. Frank C. Pellett of Atlantic, a

\footnotetext{
${ }^{75}$ In the various proceedings of the Iowa Academy of Science may be found many papers on the fauna and flora of Iowa. Those which wholly or in part relate to the plants or animals of southwestern Iowa are as follows, in the order of their publication:

Vol. I, Part 2, 1890-91. I. H. Pammel, "Report of the Committee on State Flora," pp. 88-92. Herbert Osborn, "Catalogue of the Hemiptera of Iowa," pp. 120-131.

Vol. II, 1894. H. F. Wickham, "Coleoptera of Iowa," pp. 45-51.

Vol. III, 1895. L. H. Pammel, "Notes on the Flora of Western Iowa," pp. 106-135.

Vol. V, 1897. T. J. and M. F. L. Fitzpatrick, "Flora of Southern Iowa," pp. 134-173.

Vol. VI, 1898. T. E. Savage, "A Preliminary List of the Mosses of Iowa," pp. 154-164. T. J. and M. F. L Fitzpatrick, "The Flora of Southern Iowa, Part 2," pp. 173-202.

Vol. VIII, 1900. James E. Gow, "Preliminary List of the Flowering Plants of Adair County," pp. 152-159. "L. H. Pammel, "The Thistles of Iowa," pp. 214-239,
} 
naturalist whose writings are widely known throughout the middle West. To his long familiarity with the local flora is due the valuable comment stating plants that are now less abundant than formerly in this region.

Acer dasycarpum Ehrh.

Aesculus hippocastanum Linn.

Agrostis vulgaris Thurb.

Aletris farinosa Linn.

Allium tricoccum Ait.

Allium cernuum Roth.

Alopecurus pratensis Linn. Amaranthus

Amaranthus albus I
Soft maple. Common in groves.

Common horse chestnut or Buckeye. Rare.

Redtop.

Star Grass.

Wild Leek. Common in woods aloug streams.

Wild Onion. Common in open woods near water.

Meadow Foxtall.

Pigweed. There are several species.

Tumbleweed.

'T, J. and M. F. L. Fitzpatrick, "Betulaceae of Iowa," pp. 169-176; "The Fagaceae of Iowa," pp. 177-196.

Vol. IX, 1901. L. H. Pammel, "Preliminary Notes on the Flora of Western Iowa Especially from the Physlographical and Ecological Standpoint," pp. 152-180. H. H. Hume, "Ustilaginae of Iowa," pp. 226-240.

Vol. X, 1902. T. J. and M. F, L. Fitzpatrick, "The scrophulariacea of Iowa," pp. 136-176.

Vol. XII, 1904. Fred J. Seaver, "An Annotated List of Iowa Discomycetes," pp. 105-120.

Vol. XIII, 1906. Charles E. Bessey, "The Forest Trees of Eastern Nebraska," pp. $75-87$.

Vol. XIV 1907. J. P. Anderson, "Iowa Erysiphaceae," pp. 15-46. Robert E. Buchanan, "Notes on the Algae of Iowa," pp. 47-84. Is H. Pammel and Estelle $D$. Fogel, "A Catalogue of the Poisonous Plants of Iowa," pp. 147-172.

Vol. XVII, 1910, B. Shlmek, "Prairie Openings in the Forest," pp. 16-19. L. H. Pammel, "The Problem of Weeds in the West" pp. 34-46. A. G. Ruthven, "Contributions to the Herpetology of Iowa," p. 198-210 r "Van Hyning and Frank C. Pellett, "Annotated Catalogue of the Recent Mammals of Iowa," pp. 211-218.

Vol. XVIII, 1911. M. P. Somes "Notes on Some Iowa Reptiles," pp. 149-159.

Vol. XIX, 1912. T, H. Macbride, "Twenty-five Years of Botany in Iowa," pp. 43-63. Harriette S. Kellogg. "Native Dye-plants and Tan-plants of Iowa with notes on a few other species," pp. 113-128. A. G. Ruthven, "Contribution to the Herpetology of Iowa,", p. 207. S, B. Fracker, "A Systematic Outline of the Ruduvidae of North America," pp. $217-247$.

Vol. XX, 1913. Frank C. Pellett, "Food Hablts of the Skunk," pp. 307-309.

Vol. XXI, 1914. D. H. Boot, "Comparison of Field and Forest Flora in Monona County, Iowa, pp. $53-58$.

Vol XXII, 1915, L, H Pammel, G, B. McDonald and H. B. Clark, “The Native and Cultivated Forest Trees and Shrubs of the Missouri River Basin," pp. 23-56. Vol. XXIII, 1916. E. L. Palmer, "A Seed Key to Some Common Weeds and Plants," pp. 335-394.

Vol. XXIV, 1917. Lloyd Wells, "Odonata of Iowa," pp. 327-333. Dayton Stoner "Notes on Some Iowa Rodents," pp. 353-356.

of the Iowa Geological Survey there is one report of special interest to this part of the state: B. Shimek, "Geology of Harrison and Monona Counties," Vol XX, pp. $426-483$.

L. H. Pammel and others,. "Grasses of Iowa," Bull. No, 1, 1901; and Part 2, 1903. L. H. Pammel and others, "The Weed Flora of Iowa," Bull. No. 4, 1913. Dayton Stoner, "The Rodents of Iowa," Bull. No. 5, 1915. B. H. Balley, "Raptorial Birds of Iowa," Bull. No. 6, 1918 .

The Interesting and valuable writings of Frank $\mathrm{C}$. Pellett of Atlantic assume a new attraction to the people of Cass County since $\mathrm{Mr}$. Pellett is a resident of Cass County. "Our Back Door Neighbors" deserves speclai mention. 
Ambrosia artemisicelolla Linn.

Amorpha fruticosa Linu.

Ampelopsis quinquefolia Michx.

Anemonella thalletroldes Spach. Aquilegla canadensis Linn.

Anemone virginiana Linn. Arisema triphyllum Torr.

Asarum canadense Linn.

Ascleplas purpurascens Linn. Asclepias syriaca Linn. Aster sagittifolius Willd. Salicifolius Alt. Astragalus caryocarpus $\mathrm{Ker}$. Baptisia tinctoria $\mathbf{R}$. Br. Belamcantha chinensis Adans. Brassica

Capsella bursa-pastoris Moench. Cassia chamaecrista Linn.

Castilleia coccinea spreng. Caulophyllum thalictroides Michx. Celastrus scandens Linn.

Celtis occidentalis Linn. Cephalanthus occidentalis Linn. Claytonia virginica Linn.

Clematis virginiana Linn. Clemetis viorna Linn.

Cnicus lanceolatus Hofim. Convolvulus arvensis Linu. Cornus stolonifera Michs. Corydalis

Corylus americana Walt. Crataegus coccinea Linn. Datura stramonium Linn. Delphinium tricorne Michx. Dentaria laciniata Muhl. Dicentra cucullaria DC.
Ragweed.

False Indigo. Occasional, usually in moist places, occasional on higher ground.

Woodbine; Virginia Creeper. Extremely common climber.

Rue Anemone.

Wild Columbine. Once common; disappearing.

Anemone. Disappearing.

Indian Turnip; Jack in the Pulpit. Common in woods.

Wild Ginger. Extremely common in moist woods.

Common.

Commion.

Aster. Common.

Willow Aster. Common.

Milk Vetch. Common on roadsides.

Wild Indigo.

Blackberry Lily. Occasional; escaped.

Two or three species.

Sheipherd's purse. Common.

Partridge Pea. Common along sandy roadsides.

Painted Cup.

Blue Cóhosh. Common in woods.

Bittersweet. Common climbing vine in woods.

Hackberry. Common in high ground .

Buttonbush. Accasional on wet land.

Spring Beauty. Common spring flower in open woods.

Virgin's Bower. Common.

Leather Flower; Small Flowered Clematis. Common.

Bull Thistle.

Bindweed.

Red Osier Dogwood. Common.

Corydalis.

Hazelnut. Common in woodland borders.

Scarlet Haw. Common in woodland borders. Jimson Weed. Common.

Larkspur. Disappearing.

Toothwort. Occasional in woods.

Dutchman's Breeches. Once very common in woods.

Echinospermum virginicum Lehm. Beggar's Lice. Common in woods.

Erythronium americanum Ker. Adder's Tongue. Once extremely common in woods. 
Eupatorium perfoliatum Linn. Euphorbia cyparissias Linn. Feniculum

Fragaria virglniana Duchesne. Geranium maculatum Linn.

Hicorla ovata Britt.

Hicoria glabra Britt.

- Humulus lupulus Linn.

Hypoxis erecta Linn.

Hydrophyllum virginicum Linn. Impatiens pallida Nutt. Inomoea hederacea Jacq. Juglans nigra Linn.

Lactuca canadensis Linn. Lepidium

Lillium philadelphicum Linn.

Lithospermum hirtum Lehm. Lonicera

Malva

Menispermum canadense Linn. Melilotus alba Lam.

Mirabilis

Monarda fistulosa Linn.

Morus rubra Linn.

Negundo aceroides Moench. Nepeta cataria Linń. Oxalis violaeea Linn. Oxalis stricta Sav. Panicum capillare Linn. Pastinaca sativa Linn. Phlox maculatum LInn.

Phlox pilosa Linn. Phlox glaberima Linn.

Plantago major Linn.

Poa pratensis Linn.

Podophylum pelitatum Linn.

Polygonum

Polygonatum biflorum Ell.
Boneset. Common.

Graveyard Moss.

Wild Strawberry. Common.

Wild Geranium; Cranesbill. Occasional in open woods.

Sheil Bark Hickory. Common in some places, entirely absent in other woods but a few miles distant.

Pignut Hickory. Common.

Hop. Common along fences along roadsides and gardens.

Star Grass.

Waterleaf. Common in open woods.

Touch-me-not. Common in moist woods.

Morning-glory.

Black Walnut. One of the most common native trees.

Wild Lettuce.

Peppergrass.

Wood Lily. Occasional in open woods, but disappearing.

Hairy Puccoon.

Honeysuckle.

Mallow.

Moonseed. Common climbing vine.

Sweet Clover.

Four-o'clock.

Wild Bergamot. Common along roadsides and pastures.

Red Mulberry. Occasional in native woods.

Box Elder. Common.

Catmint.

Woodsorrel. Common.

Woodsorrel. Common.

Tumble Grass.

Parsnip.

Sweet William. Very common woodland flower.

Downy Phlox.

Plantain.

Blue Grass.

May Apple. Formerly common; disappearing.

Knotweed. Numerous species of smartweed, heartsease, lady's thumb, etc.

Solomon's Seal. Very common in open : woods. Disappearing. 
Populus deltoides Marsh. Potentilla canadensis Linn. Prunus americana Marsh.

Prunus virginiana Linn. Prunus serotina Ehrh.

Quercus rubra Linn.

Querzus macrocarpa Michx.

Ranunculus abortivus Linn. Ranunculus fascicularis Muhl. Rhus glabra Linn.

Rhus toxicodendron Linn. Ribes

Robinia pseudacacia Linn.

Rosa setigera Michx.

Rubus occidentalis Linn.

Rudbeckia hirta Linn.

Rumex

Sagittaria variabilis Engelm.

Salix

Sambucus canadensis Linn, Sanguinaria canadensis Linn:

Sanicula marilandica Linn.

Scrophularia marylandica Gray.

Silene stellata Ait.

Silphium perfoliatum Linn. Silphium laciniatum Linn. Smilacina racemosa Desf.

Smilax ecirrhata Watson. Smilax rotundifolia Linn. Solidago

Staphylea trifolia Linn.

Stellaria media Smith.

Symphoricarpus vulgare Michx.

Taraxacum officinale Weber.

Teucrium canadeuse Linn.

Thalictrium

Tilia americana Linn.

Tradescantia virginica Linn.

Trifolium pratense Linn.

Trifolium repens Linn.

Trifolium agrarium Linn.

Trillium nivale Riddell.

Triosteum perfoliatum Linn.
Cottonwood. Common along streams.

Five-finger. Common.

Wild Plum. Common in thickets along streams.

Choke Cherry. Common.

Wild Black Cherry. Common.

Red Oak. A common native tree.

Bur Oak. Common. Only two oaks are common in Pymosa township.

Buttercup.

Buttercup.

Smooth Sumac. Common.

Poison Ivy. Common.

Wild Gooseberry.

Black Locust. Common.

Wild Rose.

Black Raspberry. Common in open woods. Blackeyed Susan. Common.

Sorrel.

Arrowhead. Common in marshy ground.

Willow. Common. Several species.

Common Elder.

Bloodroot.

Black Snakeroot.

Figwort; Simpson Honey Plant. Common.

Starry Campion. Disappearing from woodland.

Cup Plant. Common.

Compass Plant. Common.

False Solomon's Seal. Common in open woods.

Smilax. Native.

Greenbriar. Common in woods.

Golden-rod. Several species. Common.

Bladder Nut. Formerly common.

Chickweed.

Coral Berry; Indian Currant. Common.

Dandelion.

Wood Sage; Germander. Common in open woods.

Meadow Rue.

Basswood; Linden. Common tree.

Spiderwort. Common on moist ground.

Red Clover.

White Clover.

Yellow Clover.

Dwarf White Trillium; Wake Robin. Getting rare.

Horse Gentian. Common in woods 
Typha latifolia Linn. Ulmus americana Linn.

Ulmus fulva Michx.

Verbascum thapsus Linn.

Verbena urticæfolia Linn.

Verbena stricta Vent.

Vernonia

Vibernum prunifolium Limn.

Viola canadensis Linn.

Viola pedata Linn.

Viola pubescens Ait.

Vitis cordifolia Michx.

Xanthoxylum americanum Mill.
Cat-tail Flag.

White EIm. Very common.

Slippery Elm. Common.

Mullein.

White Vervain. Common.

Hoary Vervain. Common.

Ironweed.

Black Haw. Disappearing.

Blue Violet. Common.

Birdfoot Violet.

Yellow Violet. Common in woods.

Frost Grape.

Prickly'Ash. Common shrub.

SOME OF THE BIRDS OF CASS COUNTY, IOWA.

For this list of birds I am indebted to Miss Besse S. Tilton, teacher of science at the Atlantic High School, 1913 to 1917, and to Mr. Frank C. Pellett ${ }^{76}$ of Atlantic.

No.

201 Butorides virescens virescens (Linn). Little Green Heron.

289 Colinus virginianus virginianus (Linn.). Bob-white.

316 Zenaidura macroura carolinensis (Linn.). Mourning Dove.

331 Circus hudsonius (Linn.). Marsh Hawk.

337 Buteo borealis borealis (Gmel.). Red-tailed Hawk.

339 Buteo lineatus lineatus (Gmel.). Red-shouldered Hawk.

360 Falco sparverius sparverius (Linn.). Sparrow Hawk.

373 Otus asio asio (Linn.). Screech Owl.

387 Coccyzus americanus americanus (Linn.). Yellow-billed Cuckoo.

388 Coccyzus erythrophthalmus (Wils.). Black-billed' Ouckoo.

390 Ceryle alcyon (Linn,). Kingfisher.

$394 \mathrm{c}$ Dryobates pubescens medianus (Swains). Downy Woodpecker.

406 Melanerpes erythrocephalus (Linn.). Red-headed Woodpecker.

412 Colaptes auratus auratus (Linn.). Flicker.

417 Antrostomus vociferus vociferus (Wils.). Whip-poor-will. Formerly common, now rare.

423 Chaetura pelagica (Linn.). Chimney Swift.

428 Archilochus colubris (Linn.). Ruby-throated Hummingbird.

444 Tyrannus tyrannus (Linn.). Kingbird.

456 Sayornis phoebe (Lath.). Phoebe. (Very rare, formerly abundant).

461 Myiochanes virens (Linn.). Wood Pewee.

477 Cyanocitta cristata cristata (Linn.). Blue Jay.

488 Corvus brachyrhyachos brachyrhynchos (Brahm). Crow.

495 Molothrus ater ater (Bodd.). Cowbird.

498 Agelaius phoeniceus phoeniceus (Linn.). Red-winged Blackbird.

501 Sturnella magna magna (Linn.). Meadowlark.

506 Icterus spurius (Linn.). Orchard Oriole.

507 Icterus galbula (Linn.). Baltimore Oriole.

511 b Quiscalus quiscula aeneus (Ridgw.). Bronzed Grackle.

Passer domesticus domesticus (Linn.). English Sparrow.

529 Astragalinus tristis tristis (Linn.). Goldfinch.

552 Chondestes grammacus grammacus (Say). Lark Sparrow.

${ }^{76} \mathrm{My}$ attention has recently been called to the list published by Mr. Pellett in Bird Lore, Vol. 15, No. 5 (1913), pp. 305-307. 
-

560 Spizella passerina passerina (Bech.). Chipping Sparrow.

563 Spizella pusilla pusilla (Wils.). Field Sparrow.

567 Junco hyemalis hyemalis (Linn.). Slate-colored Junco.

581 Melospiza melodia melodia (Wils.). Song Sparrow.

587 Pipilo erythrophthalmus erythrophthalmus (Linn.). Tohee.

593 Cardinalis cardinalis cardinalis (Linn.). Cardinal.

595 Zamelodia ludoviciana (Linn.). Rose-breasted Grosbeak.

598 Passerina cyanea (Linn.). Indigo Bunting.

604 Spiza americana (Gmel.). Dickcissel.

608 Piranga erythromelas (Vieill.). Scarlet Tanager.

611 Progne subis subis (Linn.). Purple Martin.

613 Hirundo erythrogaster (Bodd.). Barn Swallow.

616 Riparia riparia (Linn.). Bank Swallow.

622 Lanius ludovicianus ludovicianus (Linn.). Loggerhead Shrike.

631 Vireo griseus griseus (Bodd.). White-eyed Vireo.

652 Dendroica aestiva aestiva (Gmel.). Yellow Warbler.

681 Geothlypsis trichas trichas (Linn.). Maryland Yellow-throat.

687 Setophaga rusticilla (Linn.). Redstart.

704 Dumetella carolinensis (Linn.). Catbird.

705 Toxostoma rufrum (Linn.). Brown Thrasher.

721 Troglodytes aedon aedon (Vieill.). House Wren.

727 Sitta carolinensis carolinensis (Lath.). White-breasted Nuthatch.

735 Penthestes atricapillus atricaipillus (Linn.). Chickadee.

755 Hylooichla mustelina (Gmel.). Wood Thrush.

761 Planesticus migratorius migratorius (Linn). Robin.

766 Sialia sialis sialis (Linn.). Bluebird.

\section{Water for Farm Use}

Along the river valleys sand points placed at a depth of forty feet reach an abundance of water in the sands beneath the river beds. Apparently this water is free from ammonia, but it should be given a sanitary analysis to prove that it is suitable for domestic use. The only analyses available are those of the Central Iowa Poultry and Eggs Company of Atlantic, whose wells apparently penetrate this sand. The analyses of this water prove that at this point it is of a most excellent quality. The analyses are as follows, obtained through the courtesy of Mr. P. A: Casey, the Manager, an'd of the "Bureau of Animal Husbandry," Washington, under whose direction the analyses were made.

SAMPLE COLLECTED MAY 2, 1916.

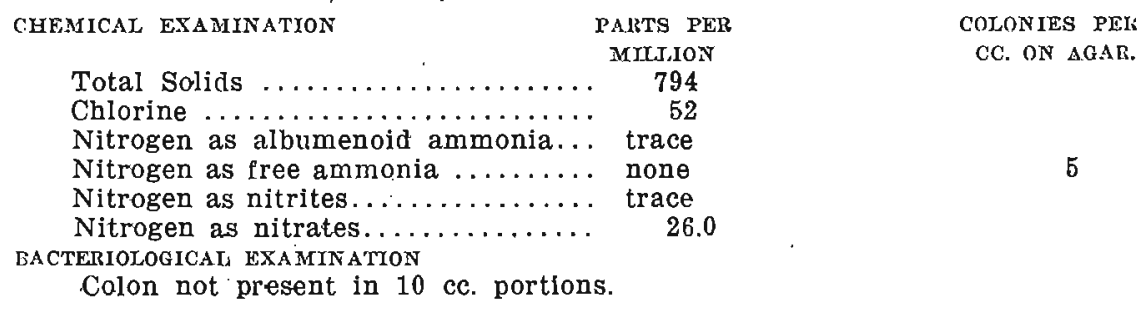


SAMPLE COLLECTED MAY 18, 1916.

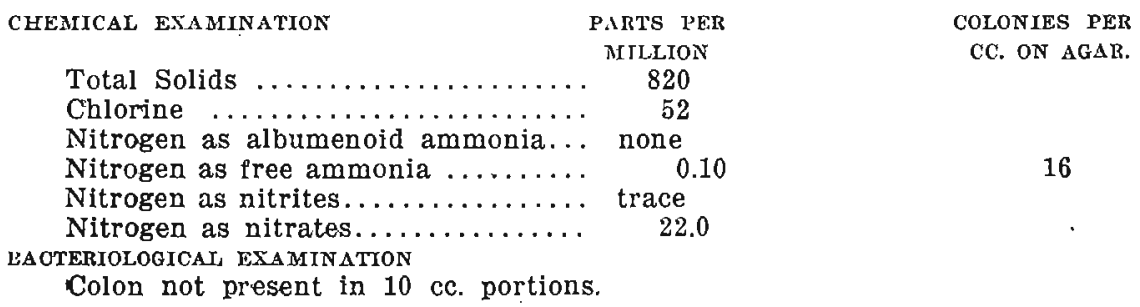

COLONIES PER CC. ON AGAR.

In the western part of the county wells on the upland and hillsides which pass through the loess into the Kansan drift reach water that is excellent in quality and is sufficient in abundance for all times except those of drought. Commonly, however, wells in the upland are drilled down into the Dakota sandstone, where there is always an abundance of water, generally of an excellent quality, at a depth of 117 to 170 feet beneath the upland. In the next two ranges of townships to the east there are in the upland many wells that penetrate the Dakota sandstone and loose sand that is described as quicksand. In the east range of townships there are also wells averaging 189 feet in Grant and 248 feet in Lincoln township; but in Massena and Victoria townships the inhabitants do not at present choose to go beneath the Kansan drift, which is here very thick. In Victoria township the eleven wells of which records were obtained have an average depth of 47 feet, the deepest being 109 feet deep and the shallowest 32 feet. The water in all of these wells is of excellent quality, when the top of the well is properly cared for; and the quantity is said to be ample in the case of those wells situated along the sides of shallow ravines.

There are four areas in which deep wells have supplied carbon dioxide gas or other evidence that the source was in an abundance of decaying vegetation. In section 5 of Grant township (northeast quarter of the mortheast quarter) a well 105 feet deep penetrates a deposit that contains wood. Carbon dioxide gas bubbles out in quantity sufficient to extinguish a lamp. The water is soft and at times seems oily. In section 24, Franklin township (southwest quarter of the northwest quarter), a well 184 feet deep, penetrating nine feet of sand- 
stone, gave a strong flow of gas from the sandstone. The nine feet of water obtained is described as hard and as containing iron. In section 25 (southeast quarter of the southwest quarter) a well of about the same depth gave a constant flow of carbon dioxide gas. Across the road south (section 36, northeast quarter of the northwest quarter) a well 178 feet deep which goes through the drift also gives a flow of this same gas. A severe stomach trouble associated with the drinking of water from two of the above wells seems due to the presence of ammonia in abundance from decaying vegetation. While strong men may be able to stand the irritating effect of water charged with ammonia, such wells yielding gas should be condemned as unsafe for drinking purposes for human beings although not for cattle, until on sanitary analysis they are found to be free from ammonia.

There is little to be gained from a tabulated list of records of wells that stop in the Kansan gumbotil or in the Kansan drift. Such wells, thirty feet or so in depth, are to be found everywhere in the upland. Records of deeper wells that reach through the drift have already been given. A few other wells that are especially deep will be described under deep wells and test borings.

\section{DEEP WELLS AND TEST BORINGS.}

At Atlantic a prospect hole was drilled in 1888 by the Rust Artesian Well Company of Ithaca, New York, for the Atlantic Coal and Mining Company. The prospect hole is 1,310 feet deep, reaching from 1,150 feet above sea level to 160 feet below sea level. It is located just east of the pumping station and electric light plant, and a few rods north of the railroad track, in section 5 of Grove township (northeast quarter. of the southeast quarter). The record of the well, published on pages 11211122 of volume XXI, Iowa Geological Survey, by H. E. Simpsor and.W. H. Norton, is here reproduced in full. 
RECORD OF STRATA IN DEEP WELL AT ATLANTIC, IOWA

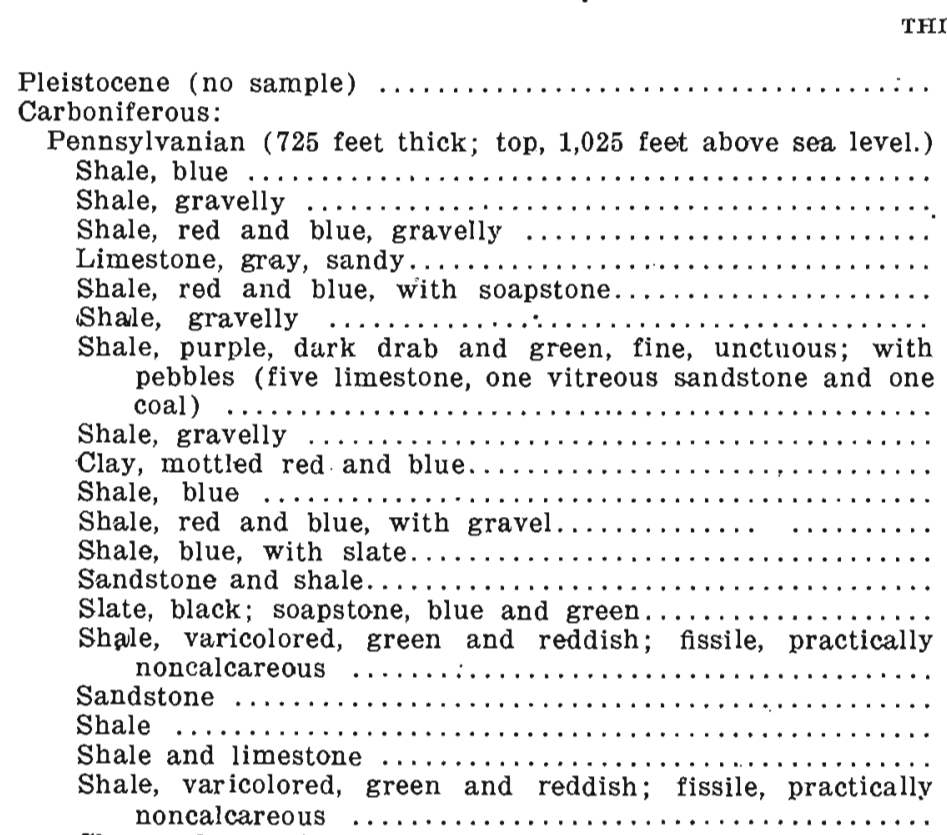

Carboniferous:

ennsylvanian (725 leet thick; top, 1,025 feet above sea level.) $35 \quad 160$

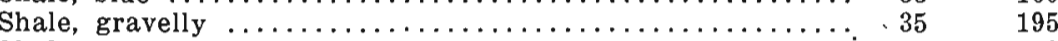

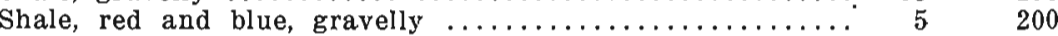

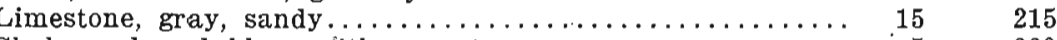

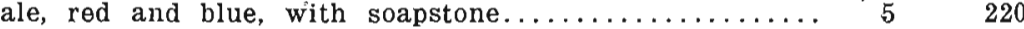

$5 \quad 225$
pebbles (five limestone, one vitreous sandstone and one

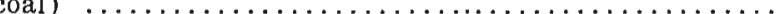

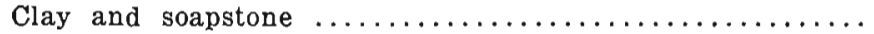

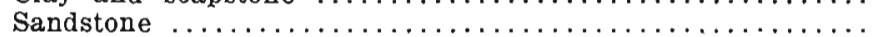

Shale, blue $\ldots \ldots \ldots \ldots \ldots \ldots \ldots \ldots \ldots \ldots \ldots \ldots \ldots \ldots \ldots$
Shale, dark gray, very finely laminated, somewhat calcareons

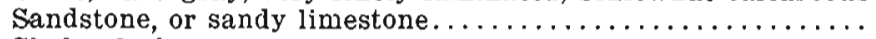

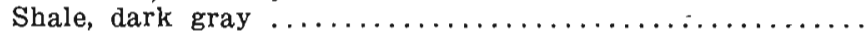

Shale, dark brown-gray, noncalcareous, arenaceous, pyriti-

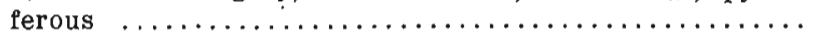

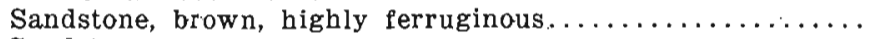

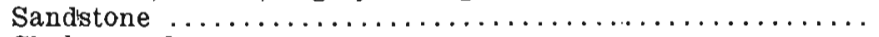

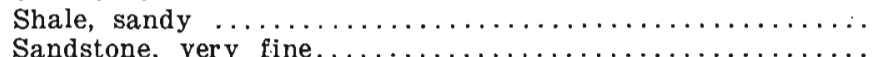

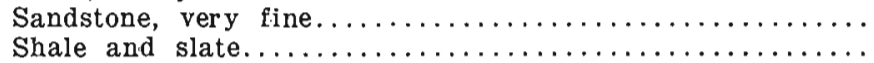

Shale, iron gray, finely laminated, noncalcareous.........

Sandstone, white, very fine. $\ldots \ldots \ldots \ldots \ldots \ldots \ldots \ldots \ldots \ldots$

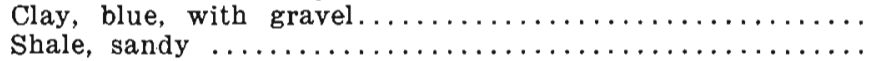

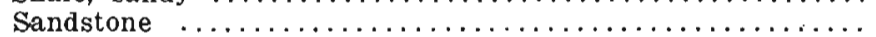

Shale, finely arenaceous, ocherous, some black..........

Shale, black, carbonaceous $\ldots \ldots \ldots \ldots \ldots \ldots \ldots \ldots \ldots \ldots \ldots$

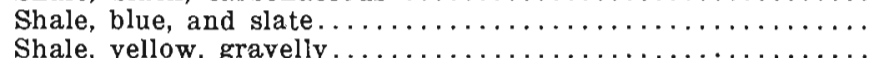

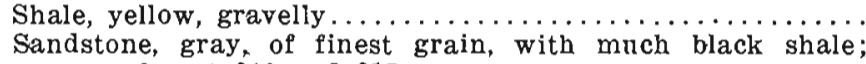

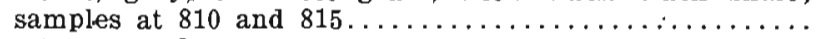

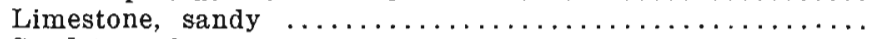

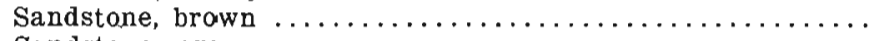

Sandstone, gray $\ldots \ldots \ldots \ldots \ldots \ldots \ldots \ldots \ldots \ldots \ldots \ldots \ldots \ldots$
Mississippian $(420$ feet thick; top, 300 feet above sea level) Limestone, white, nonmagnesian; white chert constitutes the

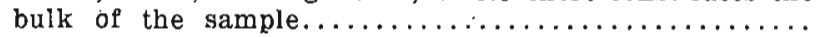

$\begin{array}{rr}15 & 480 \\ 25 & 505 \\ 12 & 517 \\ 23 & 540 \\ 10 & 550 \\ 15 & 565 \\ & \\ 20 & 585 \\ 5 & 590 \\ 10 & 600 \\ 30 & 630 \\ 30 & 660 \\ 15 & 675 \\ 10 & 685 \\ 10 & 695 \\ 15 & 710 \\ 15 & 725 \\ 5 & 730 \\ 10 & 740 \\ 10 & 750 \\ 10 & 760 \\ 40 & 800 \\ & \\ 25 & 825 \\ 5 & 830 \\ 5 & 835 \\ 15 & 850\end{array}$


THICIKNESS DEPTI

FEET FEET

Limestone, blue-gray, argillaceous; quartzose residue, with large fragments of dark shale; probably from above...

Limestone, yellow-gray; sample chiefly dark brown flint with some chalcedonic silica; a very little quartz sand...

Flint, brown-gray, calcareous; some chalcedonic silica; much

shale in fragments $\ldots \ldots \ldots \ldots \ldots \ldots \ldots \ldots \ldots \ldots \ldots \ldots \ldots \ldots \ldots$
Flint, gray and black chalcedony; drusy quartz; some shale

Flint, brown, calcareous; some chalcedony; a little shale....

Flint and chalcedony; 5 samples; drillings largely milk-white translucent chalcedony, with brown calcareous flint and some limestone. .......................

Limestone, nearly white; much white chert; 2 samples...

Chalcedony and flint; drillings remaining after original washing made up of chalcedonic silica and blue-gray and yellow siliceous eragments which effervesce with cold dilute hydrochloric acid, but do not disaggregate; pure limestone practically absent .................

Shale and flint; shale blue-gray, somewhat calcareous.....

Limestone, soft, light yellow-gray; with silica as above, and some fragments of shale; 4 samples...............

Limestome, brown; much white chert................

Limestone, lighter colored; drillings chiefly chert; only finest sand is limestone and even this is siliceous.....

Limestone, light yellow, nearly pure; considerable shale in small fragments .......................

Limestone, as above; much chalcedony and chert........

Limestone, white, chalky, and light yellow.............

Chert; drillings of chert and chalcedony; at 1,145 feet a few rounded grains of crystalline quartz and particles of finegrained sandstone; 4 samples, all of which in mass effervesce freely in acid......................

Flint, black, yellow and red flint and jasper, with sand of rounded grains of quartz; fragments of limestone, chert

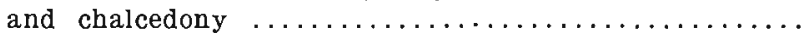

Limestone, blue-gray, cherty, and argillaceous...........

Chert, white and brown; some shale in sample..........

Limestone, cherty, gray in mass.................

Limestone; siliceous material constitutes one-tenth of sample

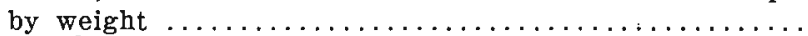

Chert and shale, buff; chert effervescent; shale pink, in fine grains, but slightly calcareous ................

Limestone, highly arenaceous and siliceous; chert and chalcedony; two-fifths of sample by weight insoluble.....

Sandstone, highly calciferous; limestonè arenaceous; quartz in minute angular particles; white and yellow-gray;

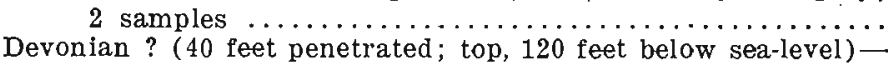

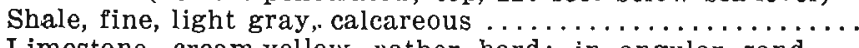

Limestone, cream-yellow, rather hard; in angular sand...

75

5

10

5

5

45

15

1,030

1,045

30

1,075

$5 \quad 1,080$

$40 \quad 1,120$

$5 \quad 1,125$

与 1,130

$5 \quad 1,135$

$5 \quad 1,140$

51,145

25

1,170

$10 \quad 1,180$

$10 \quad 1,190$

$10 \quad 1,200$

$25 \quad 1,225$

$20 \quad 1,245$

$10 \quad 1,255$

$5 \quad 1,260$

$10 \quad 1,270$

$15 \quad 1,285$

$25 \quad 1,310$

There are six other wells in the county or close to it that reach a depth of three hundred feet or more. The meagre information now obtainable concerning them is as follows: 


\begin{tabular}{l|l|l}
\hline LOCALION & LOG IN FEET \\
\hline
\end{tabular}

T. 76 N., R. 26 W., Sw. 600 feet deep 1/4. of the Sw. or. of section 9, Grove township.
Drilled in 1902 by Park Meridith, Atlantic.

T. 76 N., R. 25 W., Se. 370 feet deep

Drill hole was for coal. $1 / 4$. of the Se. qr. of section 36, Franklin township. Mr. Spees; on low upland.

A few rods west of $T .75520$ feet deep. N., R. 37 W., Sw. $1 / 4$ of the At $200 \mathrm{ft}$ struck top of Sw. qr. of section 7 . C. $H$. limestone.

Rossell in Pottawattamie At $400 \mathrm{ft}$ struck bottom of county. On upland. limestone.

At 530 it. got water; of salty taste.
T. 75 N., R. 37 W., Se. $1 / 4$ of the Se. qr. of section 10, Cass township. Old city well at Lewis.
70 ft. Soil; clay and Old city well, drilled in pebbles; sand, 1900 by Wo. Britton, white.

$31 / 2$ ft. Sandstone, hard dark brown.

$188 \%$ ft. Iimestone, shale etc.

562 ft. In black shale.

T. 75 N., R. 34 W., Sw. 306 ft. deep: mostly blue $1 / 4$ of the $\mathrm{Nw}$. qr. of section 27, Massena township. On upland.

T. 74 N., R. 34 W., Se. $1 / 4$ of the Se. qr. of section 5 , Victoria township. On upland. clay, a little sandstone, no heavy limestone, some coal.

$385 \mathrm{ft}$. deep. (A t $\mathrm{th}$ is depth found thin coal under sandstone). Cedar Rapids, Ia. Struck water at $83 \mathrm{ft}$., and none below that; well not now in use.

Struck 4 in. of coal at 410 ft.
Water rose 190 it.; has to be pumped $340 \mathrm{ft}$. It is good for washing and cooking.

\section{Water for Municipal Use}

Atlantic, Anita, Cumberland, Griswold, Lewis and Marne lave municipal water systems each owned by the city and managed by the city council through a waterworks committee. At Wiota and Massena the inhabitants are dependent on wells and cisterns. 
To reach the deep waterbearing strata penetrated at Stuart, Iowa, the deep well at Atlantic must be sunk 1,746 feet deeper than its present depth; but when that increased depth is reached the water to be obtained here is so saline that it is not acceptable. The present solution of the problem for a municipal water supply at Atlantic is much more satisfactory. The same fact holds with reference to deep wells at each of the towns in the county. The water from river sand properly guarded is better than the saline water found in such deep wells in this part of Iowa.

\section{ATLANIIC ${ }^{\mathrm{it}}$. \\ Population 5,039}

The wells which supply the city of Atlantic are located in the northern part of the city, on the terrace that borders the south side of Troublesome creek. There are forty six-inch wells in all, some of which are fifty-five feet deep and some ninety-two feet deep. The first twenty to twenty-five feet is said to be of "filled in material," then comes five feet of blue clay and five or six feet of sand and gravel. Beneath this is a sandstone, and shale, regarding which there is no complete record. From these wells the water is pumped through the city mains under a pressure of 85 to 90 pounds per square inch. The railroad uses 150,000 gallons per day, at a cost of three cents per thousand, and the city 600,000 gallons per day, on which the charge is thirty cents per thousand for the first five thousand, and ten cents per thousand for the next five thousand. In the eity there are at the present time one hundred and twenty-five hydrants and twelve hundred users. A five mill tax for water and a five mill tax for light are expected to liquidate the indebtedness in ten years.

In the following table a series of analyses of the city water is given, together with a standard analysis and an analysis of water from the creek near at hand for comparison. These give the changes in the tests while the plant was, being perfected. At times of flood, water from the creek formerly contaminated the wells, but the difficulty is now overcome. 
ANALYSES OF CITY WATER, ATLANTIC, IOWA.

\begin{tabular}{|c|c|c|c|c|c|c|c|c|c|}
\hline Parts Per Million & 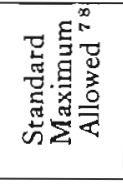 & 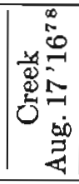 & 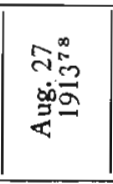 & 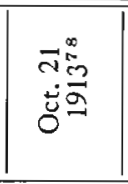 & 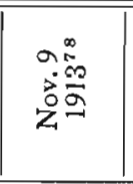 & 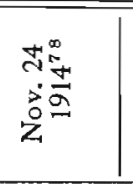 & 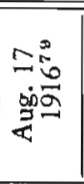 & 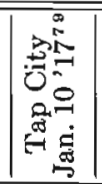 & 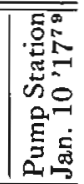 \\
\hline $\begin{array}{l}\text { Frce Ammonia } \\
\text { Nitrogen in Nitrites } \\
\text { Albumenoid Ammonia } \\
\text { Nitrogen in Nitrates } \\
\text { Ohlorine } \\
\text { Phosphates } \\
\text { Residue on evaporation.- } \\
\text { Volatile solids } \\
\text { Fixed solids } \\
\text { Iron, ferrous } \\
\text { Hardness } \\
\text { Quality }\end{array}$ & \begin{tabular}{c}
.0250 \\
.00010 \\
.1750 \\
.7500 \\
3.50 \\
1.75 \\
350. \\
\hdashline- \\
\hdashline 2.50 \\
150.
\end{tabular} & $\begin{array}{l}.085 \\
.008 \\
.075 \\
3.0 \\
4 . \\
---- \\
---- \\
---- \\
---- \\
---- \\
---- \\
----\end{array}$ & \begin{tabular}{c}
.6500 \\
$*$ \\
.0025 \\
1.2000 \\
3.15 \\
.75 \\
333. \\
91. \\
242. \\
4.98 \\
\hdashline$\vdots$
\end{tabular} & \begin{tabular}{l}
.0590 \\
.00010 \\
.0165 \\
1.25 \\
8.00 \\
.15 \\
251. \\
151. \\
100. \\
\hdashline-2. \\
-2.
\end{tabular} & \begin{tabular}{l}
.0850 \\
.00015 \\
.0075 \\
1.55 \\
8.15 \\
$\dagger$ \\
231. \\
97. \\
134. \\
\hdashline \\
\hdashline 8
\end{tabular} & $\begin{array}{l}.0950 \\
.00005 \\
.0450 \\
2.0000 \\
9.50 \\
+ \\
264 . \\
105 . \\
159 . \\
-\end{array}$ & $\begin{array}{l}.025 \\
.003 \\
.010 \\
3.0 \\
9.0 \\
----- \\
---- \\
---- \\
---- \\
---- \\
----\end{array}$ & $\begin{array}{l}.060 \\
.006 \\
.010 \\
4.0 \\
10 . \\
---- \\
--=- \\
---- \\
-\overline{3.0} \\
----- \\
-----\end{array}$ & 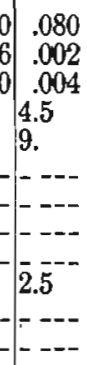 \\
\hline $\begin{array}{l}\text { Bacteria per c. c. at } 37 \\
\text { Bacteria per c. c. at } 20^{\circ} \\
\text { Colon Bacilli, acid colo } \\
\text { Gas ............. } \\
\text { *None. } \\
\text { †High. } \\
\$ \text { Not very satisfactory } \\
\text { \$Sewage indications. } \\
\text { ¡Poor. }\end{array}$ & $\begin{array}{l}\text { C., on } \\
\text { C., on } n \\
\text { onies per } \\
\ldots \ldots \ldots\end{array}$ & $\begin{array}{c}\text { litmu } \\
1 \text { c. } \\
\ldots \ldots\end{array}$ & $\begin{array}{l}\text { Is lact } \\
\text { nt aga } \\
\text { c.... }\end{array}$ & agar & $\cdots$ & & & $\begin{array}{r}5 \\
300 \\
0 \\
0\end{array}$ & $\begin{array}{r}26 \\
35 \\
2 \\
0\end{array}$ \\
\hline
\end{tabular}

Significance of Water Analyses.-In water analyses the free ammonia represents organic material that has already decayed; the albumenoid ammonia represents organic matter that has not yet decayed. The nitrites are formed during incomplete decay, and the nitrates are formed in the final step of decay. Consequently a perfectly pure water would give no traces whatever of ammonia, nitrites and nitrates. An excess, especially of ammonia, is an irritant to the digestive tract which may not affect a person in good health but prove harmful to a person who is not strong. Such water may also contain food for disease germs amid which they will multiply. There is a small amount of chlorine in even the best of well water, the amount varying for different localities. Excess of chlorine is an indication of contamination from the surface. In the case of wells for domestic purposes surface contamination is indicated also by minute living organisms than can be seen swimming and crawling about in water pumped from the well, which some

"Analysis made by C. N. Kinney, Des Moines.

${ }^{70}$ Analysis made by State Board of Health, Iowa City. 
people seek to exclude by straining the water, instead of carefully cleaning the well out, making the planking tight, and grading around the well so that water flows away from the well and does not stand in pools.

In the case of the city wells at Atlantic there has been an endeavor to exclude surface water by cementing carefully the openings from the pits into the wells and to keep as far as possible all surface and oreek water out of the pits in time of flood. The last two analyses, those of January 10, 1917, were made after the final cementing of the pits. A comparison of them indicates that flushing of the pipes had not been completed. A statement of the last bacterial analyses is included in the above table. To attain the elimination of bacteria it is in some places customary to inject into the water a small amount of chlorine gas, a precaution that is not taken at Atlantic. The last analysis given indicates that Atlantic now has a municipal supply that may be considered satisfactory, though it will require the continuance of the present care to keep the water unimpaired.

\section{ANITA $^{\text {so }}$ \\ Population 1,210}

Anita gets its municipal water supply from eight bored wells six inches in diameter, thirty-six feet deep, extending into the sand and gravel beneath Turkey creek in the southwest part of the town. The water is pumped by a 25 -horsepower St. Mary (Ohio) gasoline and oil engine operating a Gardiner pump (Quincy, Illinois) the capacity of which is rated at 250 gallons per minute. It is pumping 6,000 gallons per day into two pressure tanks (Curtis, St. Louis, Missouri) 34 feet in length, nine feet in diameter, with rated capacity of 18,000 gallons each, at 120 pounds pressure. Thirty-five dollars per month cover the entire cost of operating this plant. There are twenty hydrants and at present seventy-one users. There is a minimum rate of two dollars per year, which allows the use of 4,000 gallons at fifty cents per thousand gallons, beyond which the price is forty-five cents per thousand gallons up to 6,000 gallons, and forty cents per thousand gallons from 6,000 to 10,000

${ }^{80}$ Data furnished by J. C. Jenkins, City Clerk. 
gallons, above which there are special rates. There is a five mill tax for running expenses, and a sinking fund of three mills for interest on the $\$ 19,000$ bonds.

At the wells there are twenty feet of black washed soil, ten feet of gray sand and yellow clay, and five feet of sand and gravel. Apparently this bed of sand is not a lens of small extent if we may judge by the abundance of water that it carries. The water-bearing sand and gravel appear to be post-Kansan. Immediately beneath the five feet of sand and gravel is blue Nebraskan clay which extends to a depth of 100 feet, at which depth there was encountered a layer of preglacial sand that contained water saturated with iron. Consequently the boring was closed and the supply was taken from the sand and gravel at thirty feet. No analysis of the water is available.

At the old city well in the northeastern part of town at a depth of 180 feet there was reached a water-bearing bed of sand at the base of the blue clay. The pumping of water from this well has been discontinued.

\section{CUMBERLAND ${ }^{\wedge 1}$}

\section{Population 574}

Cumberland gets its water from a six-inch well near the business portion of the town, drilled to a depth of 163 feet. To obtain the 10,000 gallons of water needed per day a RawleighSchryer ten-horsepower gas-oil engine is used to run a Gould's pump, diameter 33/4 inches, 16 -inch stroke, speed 275 revolutions per minute. The water is pumped into a steel tank placed on a tower sixty feet high on ground which is sixty feet above the main street.

A windmill with twelve-foot wheel has been placed over a well 214 feet deep close by the stand pipe with a view to obtaining as much water as possible by windpower. This pump has a cylinder three inches in diameter and an eight-inch stroke. There are thirteen street hydrants on a six-inch main. The cost of running is such that the ninety users will yield a profit

${ }^{81}$ Data furnished by W. R. Noland, Superintendent of Water System. . 
of seventy cents per thousand, without allowance for hydrants. To obtain the plant complete the town has been bonded for $\$ 12,500$.

The log reported for the well is as follows:

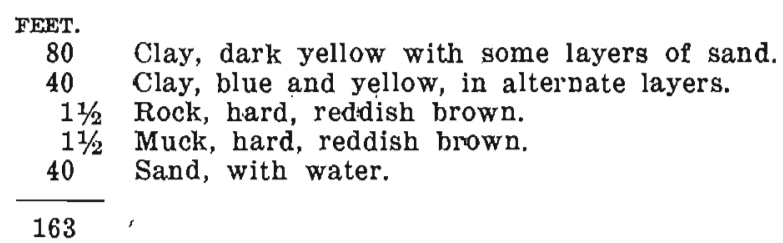

The water is soft enough to be used without breaking it; pnmping at the rate of three gallons per minute does not lower it in the well. The water is judged to come from preglacial deposits.

The following is a copy of an analysis by Professor C. N. Kinney, reported December 5, 1914.

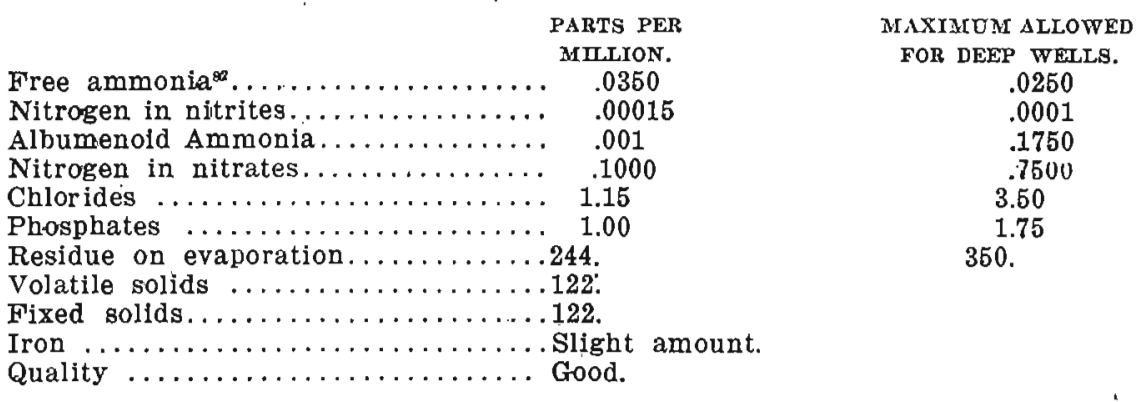

\section{GRISWOLD ${ }^{\text {RG }}$}

Population 1,148

The municipal supply of Griswold is obtained from an eightinch cased well sunk to a depth of 140 feet from the level of the terrace on which the town is situated. A twelve-horsepower Hercules gas engine (Evansville, Ind.) operates a Deming (Salem, Ohio) pump having an eight-inch cylinder and a twentylour inch stroke, twenty-four revolutions per minute, thus deiivering 120 gallons per minute. The water is pumped into a standpipe, capacity 58,000 gallons, from which 1.17 consumers are supplied. The flat rate is $\$ 5,00$ per year. for general domes-

\footnotetext{
See previous discussion of slgnificance of water analyses.
}

suata furnished by D. H. Scott, City Clerk. 
tic purposes and $\$ 2.50$ per bath room. There is also a five mill water tax. The entire receipts net $\$ 1,500$ per year, with cost of running but $\$ 500$. Under such receipts and expenditures the original cost of $\$ 13,000$, was paid long ago, the city now having a yearly income of $\$ 1000$ from the plant.

The log of the well is as follows:

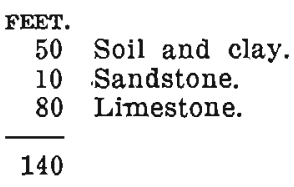

Evidently the water comes from the Dakota sandstone. Unfortunately the water has not been analyzed. It is heavily charged with iron.

\section{LEWIS $^{84}$}

\section{Population 652}

The city well is located in the public square, 1,102 feet above sea level and about 105 feet above the level of the water above the dam. It is a well ten feet in diameter and sixty-four feet deep, dug in 1913, and walled with concrete blocks locked together.

A six-horsepower Fairbankś-Morse gasoline engine is used to run a: Deming pump, diameter four inches, stroke two feet, at the rate of twenty revolutions per minute. The pump is kept Junning a considerable portion of each day, forcing water into the 40,000 gallon tank, which is 16 feet in diameter and 80 feet kigh. About 20,000 gallons are used per day. There are seven hydrants and 143 consumers; water rate $\$ .75$ per thousand gallons.

The log of the well is as follows:

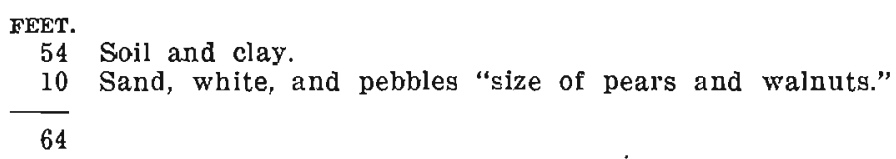

The well constantly has seven feet of water that cannot be pumped out. The water apparently comes from preglacial sand and gravel and also from Dakota sandstone and sand de-

\footnotetext{
*Data furnished by Mr. Fletcher.
} 
rived from it. From the record of Mr. J. C. Livingston given below it will be seen that the Dakota sandstone is immediately beneath where the new well stops. The Dakota sandstone is abundant in all directions.

Mr. J. C. Livingston reports the following log of the "old" city well drilled about 1900 by Mr. William Britton of Cedar Rapids, Iowa. The well is not now in use.

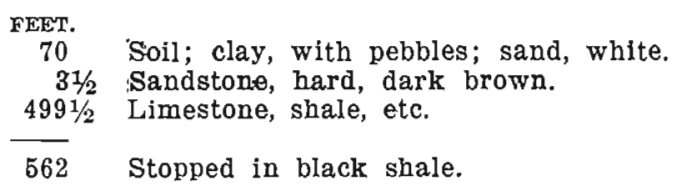

Water was struck at a depth of 83 feet, and none below that. Fourteen inches of coal was found at a depth of 410 feet.

\section{MARNE $^{\mathrm{ss}}$}

\section{Population 297}

The municipal supply of water at Marne is obtained from a si.x-foot well dug thirty-five feet deep, on a small flat near the railroad track, about 1,200 feet above sea level. A six-horsepower combined pump and engine (The Thomas Company, Beloit, Wisconsin) pumps the water through a four-inch main io a tank in the northern part of the town which is twenty feet in diameter, sixteen feet high, with a capacity of 1,200 barrels and rests on a base twenty feet above the ground. The thirty users pay $\$ 7$ per year flat rate. There are seven hydrants. The income from the water rates is $\$ 210$ per year, to which is added a five mill tax which yields $\$ 160$, making the total income $\$ 370$, which just about pays the cost of operation. The plant cost as follows :

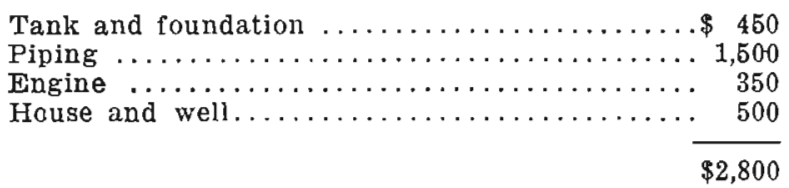

sata furnished by Andrew Lastime, City Clerk. 
The following analysis was made by Professor C. N. Kinney of Des Moines, January 15, 1913 :

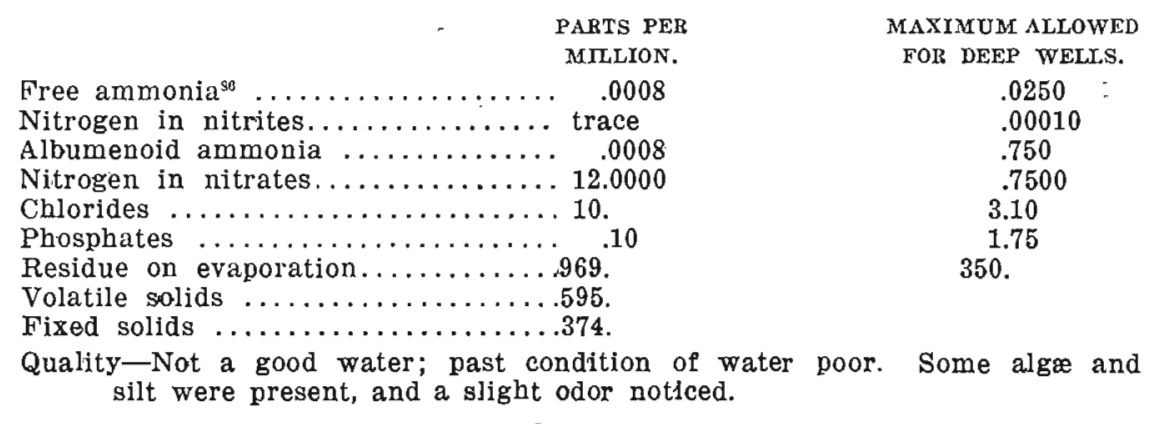

One reason, and probably the only reason, why the water was not a good water was evident in the former lack of care of the top of the well. The difficulty has been remedied.

\section{Springs}

At Crystal Lake, a mile south of Lewis, the base of the Dalsota sandstone is about fifteen feet above the bottom of the ravine near at hand. From the base of the sandstone pipes lying on the shale beneath carry streams of the purest water into a bathing pool made by damming up a portion of the ravine. The further addition of lunch counters, swings and various accessories of a picnic ground have converted this shady retreat beneath the sandstone cliff into a delightful pleasure resort.

Not so fortunate is that other old Indian spring at Spring Creek a mile west of Lewis where the special beauty of sandstone cliffs is not so extensive as at Crystal Lake. At Spring Creek the water from the sandstone seeps through a heavy cleposit of talus on the side of a ravine in a pasture.

Near Galion at a point three miles south of Lewis and four and a half miles east, the cliff and the grove are as attractive as at Crystal Lake, but the base of the sandstone is near the level of the creek bed. With considerable labor it would be rossible to remove the mud and protect the springs at the base of the sandstone.

Along the Nodaway river from the central part of Edna township (section 15) to Massena there are numerous springs giving the Nodaway a never-failing supply. Nearly all of this

\footnotetext{
${ }^{85}$ See previous discussion of significance of water analysis.
} 
water comes from the Dakota sandstone, which is visible at numerous places along the course of the stream; but near Massena it is possible that water from preglacial deposits mingles with that from the Dakota sandstone. In several places along the stream small ponds have been easily prepared to the delight of ducks, swine and cattle. Half a mile east of Cumberland water from a similar'source forms pools in the river bed in dry seasons.

North of Cumberland the creek is abundantly supplied with spring water for two miles upstream from the west center of section 15. As wells in this portion of the township go to sandstone it is probable that a considerable portion of this water comes from the sandstone. A portion of the water on the north side of the river comes from the preglacial deposits, which iocally are evident and two miles to the northeast furnish an abundance of carbon dioxide gas to the wells.

\section{Oil}

No evidence of oil is reported at the prospect hole at Atlantic which as stated on page 253 is 1,310 feet deep. Scum caught back of sticks in the water of ravines was tested and found to give no trace whatever of oil. The so-called oil reported on the water from wells was not accompanied by any evidence that :t was due to other cause than decay in swampy deposits peneirated by the wells. The accompanying gas was carbon dioxide. Two of these three wells (section 36, Franklin township and section 5, Grant township) have already been mentioned with reference to preglacial swamps. The other well reached the Dakota sandstone in Pleasant township (northeast quarter of the northeast quarter of section 20) at a depth of fifty to sixty feet.

\section{Coal}

The fault plane which is traced northeast-southwest from section 33, Edna township, to section 1, Victoria towrship, divides Cass county into two distinct but unequal parts.

North of the Fault Plane.-Nowhere north of the fault plane does the Nodaway coal exist. it having been eroded away ages ago. The coal nearest the surface in the northeast half of the 
county is the four-inch seam at the base of the Bethany Falls (Earlham) limestone. Near Anita this seam is close to the base of the Dakota sandstone and glacial drift at a depth of 189 feet below the upland. Hence it is absent to the northeast of the place named. At Atlantic it is the coal recorded at a depth of 260 feet in the test boring. At Griswold it is estimated to be about 724 feet below the town, or 430 feet above sea level.

About seventy-one feet below the above named seam is the horizon of the twenty-inch seam of coal mined at the Eureka toal shaft, located two and a half miles east of the northeast corner of Lincoln township, where it was found at a depth of 260 feet below the upland: With an average increase in depth of 21 feet per mile to the southwest this seam of coal is at a depth of 783 feet beneath the level of the upland, or at 534 feet above sea level, along a line from northwest to southeast, near the center of Cass county, and at a depth of 984 feet below Griswold, or at 114 feet above sea level. In the record of the Atlantic test-boring this coal is not mentioned, but the slate recorded at a depth of 365 feet, 105 feet below the first mentioned coal seam, may possibly be related to this second seam. Variations in dip and in thickness of shale make up the difference of 34 feet between 71 and 105 feet.

The possibility of the presence of coal at greater depths must for the present be treated as a rumor. ${ }^{87}$ Slate at 675 feet, at 740 to 760 feet and at 825 feet, are all that is mentioned in the record of the Atlantic test boring. These records of slate are where coal should be expected if it is present at all. It is evident that a "chuck drill" and not a core or "diamond drill" was used, for samples were taken only occasional!y.

According to the record of the Clarinda diamond drill hole ${ }^{s s}$ there are two other thin seams of coal that should be encountered in the southwestern part of the county. The first is a sixinch seam 200 feet above the coal at the base of the Bethany Falls (Earlham) limestone. This seam reaches the base of the Dakota sandstone, or the base of the glacial drift where the Dakota sandstone is absent, at about the middle of the area of

${ }^{87}$ C. R. Keyes, "Coal Deposits of Southwestern Iowa," Iowa Geological Survey, VoI. II, p. 443 . Survey, Vol. XIX, p. 618 . 
the Douglas division (see map) or along a line northwest-southeast through a point about a mile southwest of Cumberland, and two miles southwest of Marne. It is at a depth of 524 feet at Griswold. The horizon of the second, a four-inch seam, is 104 feet above the base of the Oread limestone, or at a depth of 151 feet beneath Griswold.

It is evident that none of these seams of coal are worthy of consideration for mining at the present time, unless it be the twenty-inch seam, the second one named above, which in time of need can be reached in Grant township, and in the northeast half of Benton and of Lincoln townships. Water from the Dakota sandstone and from the preglacial sands will cause trouble in mining.

South of the Fault Plane.-In the portion of Victoria and Edna townships southeast of the fault plane the Nodaway coal seam is present at a depth of approximately thirty feet below the beds of the deepest ravines, except where it has been removed by preglacial erosion, the main lines of which are about ten feet deeper. Beneath the Nodaway coal the depth to the fonr-inch seam of coal above the Deer Creek limestone is 40 feet, or 104 feet above the base of the Oread lirnestone. The further depth to the six-inch seam in the Douglas formation is 372 feet, the further depth to the four-inch seam of coal beneath the Bethany Falls (Earlham) limestone is 200 feet, and the further depth to the twenty-inch seam (Eureka) about 71 feet.

The above figures are subject to some variation: but it is believed they are sufficiently exact to prevent useless prospecting, and to guide prospecting in Grant, Benton and Lincoln townships in time of need. It is possible that people in Massena and Union townships may think coal is easily accessible there because it is mined at Bridgewater in Adair couniy. Expenditure for prospecting will not be wise, for Bridgewater, like Briscoe, is on the opposite side of the fault plane and under conditions described for the southeastern parts of Edna and Victoria townslips.

Well Records with Reference to Coal.-The record of the Atlantic test hole has already been considered. 
At Lewis the deep well is said to have encountered at a depth of 410 feet a fourteen-inch seam of coal, which is apparently at the base of the Bethany Falls (Earlham) limestone. The thickness named, if correctly stated, is such that it includes considerable shale with the coal.

It is stated that coal was found in a well 385 feet deep in section 5, Victoria township. This is at the northenst border of the area of the six-inch seam that comes up beneath the Dakota sandstone in the area of the Douglas division. It dips to the southwest, and is too thin to be profitably mined.

It is stated that three seams of coal were encountered in a test boring 370 feet deep below a low upland, on Mr. Spees' farm, section 36 (southeast quarter of the southeast quarter), Franklin township. One seam was found at a depth of 193 feet. This is apparently the top seam, which in that locality-is the six-inch seam in the Douglas formation and is not far below the base of the Dakota sandstone. Though depths are not given the second seam may well be that at the base of the Bethany Falls (Earlham) limestone, and the third the seam reached at Eureka.

In section 27 (southwest quarter of the northwest quarter), Massena township, is a well 306 feet deep. Here coal is said to have been encountered somewhere beneath a little sandstone, which was beneath a thick blue clay. The Nodaway coal seam is beneath Dakota sandstone and a little Missouri shale in this locality.

Analyses of Coal.-The following are analyses cf coal ${ }^{89}$ from the Plowman shaft at Briscoe. They indicate a good average coal as compared with other Iowa coal.

ANALYSES OF COAL FROM THE PLOWMAN SHAFT.

\begin{tabular}{|c|c|c|}
\hline - TOP OF SEAM. & MIDDLE OF SEAMI & BOTTOM OF SEAM \\
\hline$\ldots \ldots 8.97$ & 9.09 & 8.72 \\
\hline Total combustibles........ 80.48 & 74.95 & 77.39 \\
\hline Ash $\ldots \ldots \ldots \ldots \ldots \ldots \ldots \ldots \ldots$ & 15.96 & 13.89 \\
\hline Volatile combustible matter...36.44 & 32.04 & 32.01 \\
\hline Fixed carbon $\ldots \ldots \ldots \ldots \ldots \ldots 44.04$ & 42.91 & 45.38 \\
\hline Coke-fixed carbon plus ash. .54 .59 & 58.87 & 59.27 \\
\hline Sulphur in sulphides....... 3.15 & 2.44 & 3.67 \\
\hline Sulphur in suIpliates........ .11 & .13 & .27 \\
\hline Total sulphur $\ldots \ldots \ldots \ldots \ldots 3.26$ & 2.59 & 3.94 \\
\hline Authority $\ldots \ldots \ldots \ldots \ldots$ G. E. Patrick & G. E. Patrick & G. E. Patrick \\
\hline
\end{tabular}




\section{Sandstone}

A mile south of Lewis are the old sandstone quarries where in the early history of the region the dark reddish brown Dakota sandstone was quarried for building purposes. A few buildings may still be found in which this stone was used. Though easily worked it is too soft, too porous and too unsatisfactory in color for a building stone, and is no longer quarried.

\section{Limestone}

Limestone has been quarried on the west bank of the Nishnabotna at Lewis; just south of section 32 (souttieast quarter of the southeast quarter), Noble township; in the southern half of section 36, Noble township; and in the southern part of section 31, Edna township, at the Fox quarries; but quarrying has long since ceased at each place, and the old quarry faces are largely concealed by talus. All the limestone is a light grayish Fusulina limestone.

In the old quarries at Lewis (northeast quarter of the southeast quarter of section 9) only six feet of limestone and shale appear. The top of the limestone is seventeen feet above the water in the river and about three feet above the general leve] of the bottom land. The limestone is at present better seen just north of the bridge over Spring creek in section 9 . The lower bed is four feet, ten inches thick, the upper five and a half feet thick. The two are separated by two feet of a gray shale.

What little quarrying has been done on Rose Branch was in Montgomery county. No strata in place are now visible, but the fragments at hand are of the same character of gray Fusulina limestone as that formerly quarried at Leris, and are undoubtedly from the same beds.

The full section at the Fox quarries (northeast quarter of the northeast quarter of section 31, Edna township) is given in the chapter on stratigraphy. At this place there are several beds that have been quarried, all of which are of the same general character of gray Fusulina limestone as the beds already named.

'The lowest beds, twenty-three feet above the river, offer layers four inches, ten inches, and twenty inches thick. Next 
above these lowest limestones are two heavily bedded layers with two feet between them not exposed. These beds of limestone are divided into three layers that are respectively two feet, one foot and two and one-fourth feet thick. Near the top of the bluff are two thin layers one of which is seven inches thick and one two inches thick. At the very top of the bluff is two feet of a decomposed limestone.

A small quantity of limestone could be obtained in sections 32 and 33 , Grove township, where a stratum three feet thick outcrops in the side of the ravine.

The demand for the sandstone and limestone for building purposes has been replaced by a demand for the mucle more satisfactory cement and brick; but a new local use for the limestone has arisen. Limestone crushed fine is needed or: ground that is acid, especially if alfalfa is to be raised on it.

The only deposits that are suitable for cement are those at the Fox quarries, where the right mixture of shale and limestone can be obtained; but the beds exposed are only twentythree feet thick, and they are located too far from a market to deserve consideration.

\section{Clay}

The Atlantic Brick and Tile Company plant was operated by Mr. C. E. Taylor, whose clay pit ${ }^{90}$ is located west of the city and close to the river. Here twenty-four feet of loess, the lower four feet of which is brown, the remainder yellow, lies exposed to view with base four feet above low water in the river. Beneath the loess is said to lie three or four feet of yellow sand, then two inches of gravel, which rests on four feet of a coarse river sand consisting of grains of various colors, indicating that the gravel is derived from glacial drift, and containing iron. Beneath this bed was something that Mr. 'Taylor could not penetrate. The plant is used for the manufacture of brick and tile. The manager is experimenting to obtain a mixture that will make a harder brick than the loess alone produces, and is evidently succeeding in his undertaking. At present he is operating four kilns.

\footnotetext{
DoIt has recently changed hands, and is now operated by the Atlantic Building
Supply Company. 18
} 


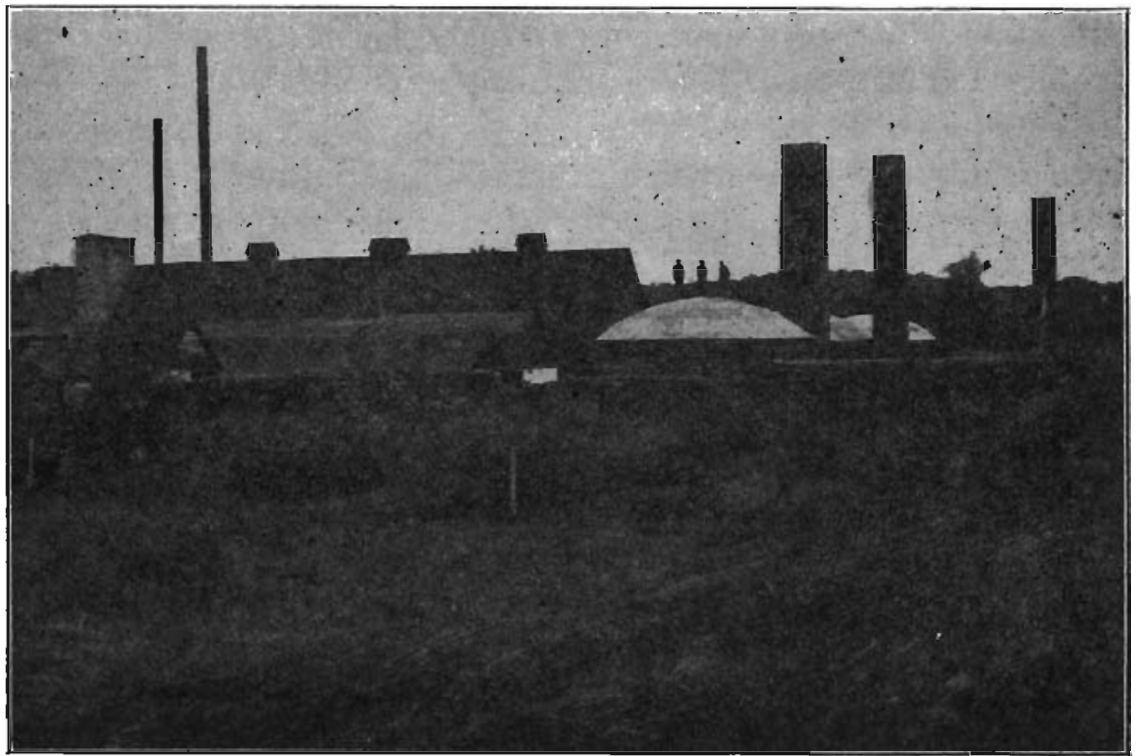

Fig. 36.-Brickyard at Atlantic, Cass county.

The pit at Anita is also in loess, from which Mr. C. L. Martin makes common brick.

The clay pit at Lewis is in loess banked against the side of the valley, on the second bottom, close to the river. As the brick made were too soft to compete with brick shipped in, the plant has remained idle since about 1912. The plant consists of a mill, two drying sheds, a rectangular kiln, two complete and two incomplete circular down-draft kilns.

There is a small body of shale one mile east of Griswold and nearly two miles south, and another body of shale two miles north and one mile west of Griswold than can be mixed with the loess to produce a harder brick than can be produced from the loess alone. Weathered Nebraskan drift is better material than loess for the manufacture of brick and tile. Dift generally contains too many pebbles, but places are common where there are few pebbles. 
TABLE OF CLAY PRODUCTION IN CASS COUNTY SINCE 1900.

(Compiled from the various volumes of the Iowa Geological Survey).

\begin{tabular}{|c|c|c|c|c|c|c|c|}
\hline 莫 & 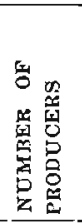 & 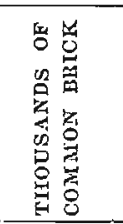 & 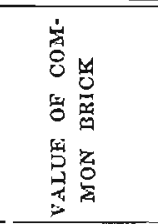 & 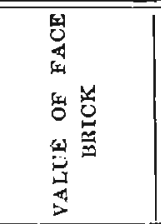 & 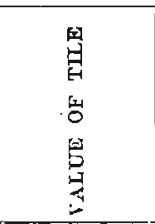 & 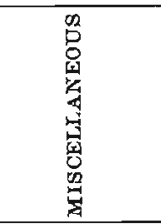 & 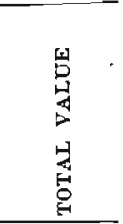 \\
\hline 1900 & & 895 & a 5975 & & & & \\
\hline 1901 & $\begin{array}{l}3 \\
5\end{array}$ & $\begin{array}{r}89 b \\
2039\end{array}$ & $\begin{array}{r}\$ 5,275 \\
14,412\end{array}$ & $\cdots \cdots \cdots$ & $\cdots \cdots \cdots$ & & $\$ 5,275$ \\
\hline 1902 & 5 & 1,670 & 12,405 & $\begin{array}{l}\cdots \cdots \\
\cdots \cdots\end{array}$ & & & $\begin{array}{l}14,414 \\
12,405\end{array}$ \\
\hline 1903 & 2 & 1,406 & 10,596 & & $\ldots \ldots \ldots$ & & 10,596 \\
\hline 1904 & 4 & $\cdot 2,020$ & 16,100 & $\ldots$ & $\$ 825$ & $\ldots \ldots \ldots$ & 16,925 \\
\hline 1905 & 4 & 1,593 & 11,420 & $\ldots$ & 1,969 & $\ldots \ldots$ & 13,389 \\
\hline 1906 & $\ldots \ldots$ & $\ldots \ldots$ & $\ldots \ldots \ldots \ldots$ & $\ldots \ldots \ldots$ & $\ldots \ldots \ldots$ & $\ldots \ldots \ldots \ldots$ & $\ldots \ldots \ldots$ \\
\hline 1907 & 7 & $\ldots \ldots \ldots$ & 13,193 & $\ldots \ldots \ldots$ & 1,682 & $\ldots \ldots \ldots$ & 14,875 \\
\hline 1908 & 2 & 5,500 & $\ldots \ldots \ldots$ & $\$ 7,000$ & 2,700 & $\$ 4,000$ & 19,200 \\
\hline 1909 & 3 & $\ldots \ldots$ & 9,465 & $\ldots \ldots \ldots$ & 6,653 & $\ldots \ldots \ldots$ & 16,783 \\
\hline 1910 & 1 & $\ldots \ldots$ & $\ldots \ldots \ldots$ & $\ldots \ldots \ldots$ & $\ldots \ldots$ & $\ldots \ldots \ldots$ & $\ldots \ldots \ldots$ \\
\hline 1911 & 2 & $\ldots \ldots$ & $\ldots \ldots \ldots$ & $\ldots \ldots \ldots$ & $\ldots \ldots \ldots$ & $\ldots \ldots \ldots$ & $\ldots \ldots$. \\
\hline
\end{tabular}

For 1912-1915 the only information published states there was one producer each year in the county.

\section{Sand}

The sand beneath the river bed along the Nishnabotna affords an ample supply for all needs at Atlantic, Lewis and Griswold, and is accessible to all who reside in the western half of the county. At the present time there is a sand pump and outfit located a mile west of Griswold, just west of the county line, where it obtains a white sand of waterworn quartz pebbles.

A second source of supply is the white sand in the upper portion of the Dakota sandstone. In section 17 (southwest quarter of the southeast quarter), Noble township, a considerable bed of this sand, so incoherent that it is easily obtained with a shovel, is valuable for local use. In the northeastern part of section 29, Edna township, is a sand bed suitable for use. Generally along the Nodaway, as well as elsewhere, the sandstone exposed contains too much iron to be satisfactory in color, and is generally too consolidated for use without crushing. 


\section{ACKNOWLEDGMENTS}

It has been the intention to acknowledge sources of information in the text as far as possible. In addition to this the writer wishes to express his appreciation of the universal courtesy which he has received from people in all parts of the county. He also wishes to express his appreciation of the care and skill of the Assistant State Geologist, Dr. James H. Lees, who has superintended the publication of the report. 
$\begin{array}{lllllll}A & U & D & \cup & B & O & N\end{array}$

$\begin{array}{clllll}C & \mathrm{U} & \mathrm{N} & \mathrm{T} & \mathrm{Y}\end{array}$

(n)

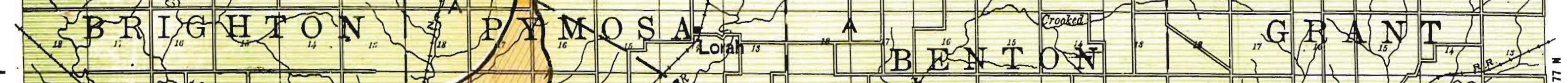
$>$ (n)

$=2$

$=2$ (2)

0 (

0 Ans. A 1.3. (1)

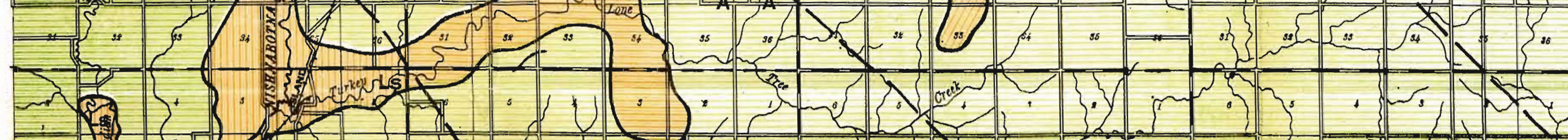
(2)

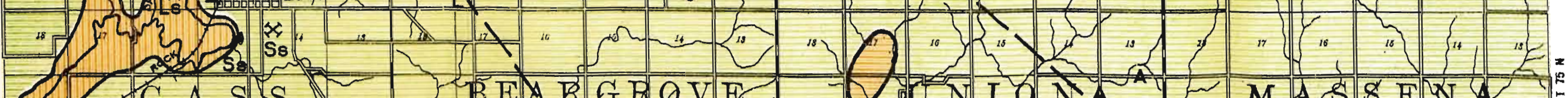

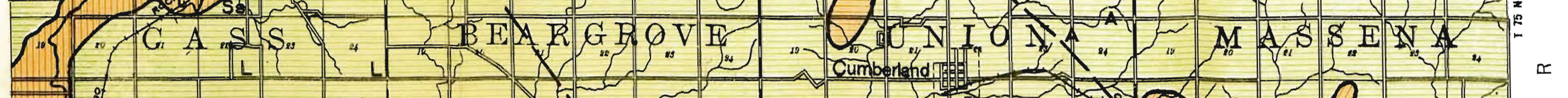
(I)

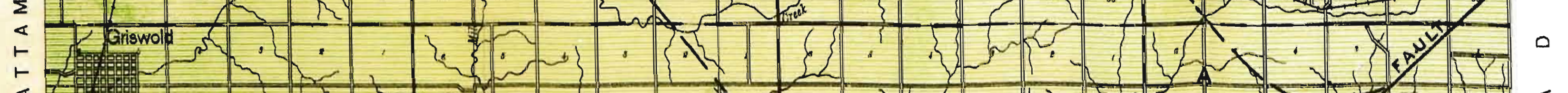

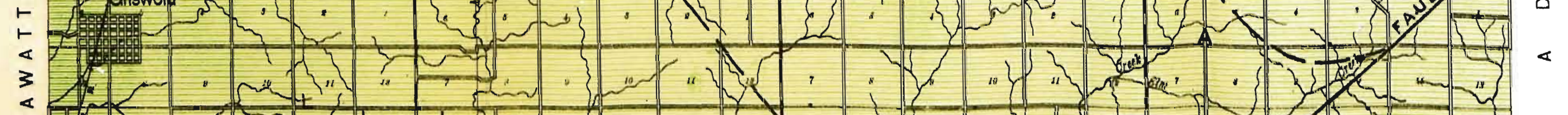
LE

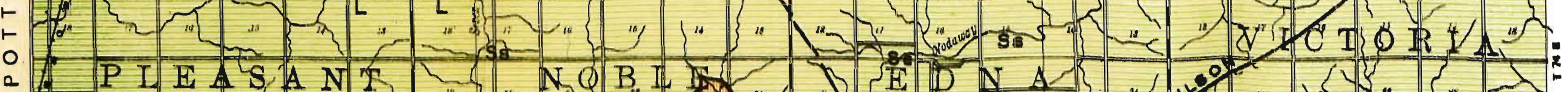

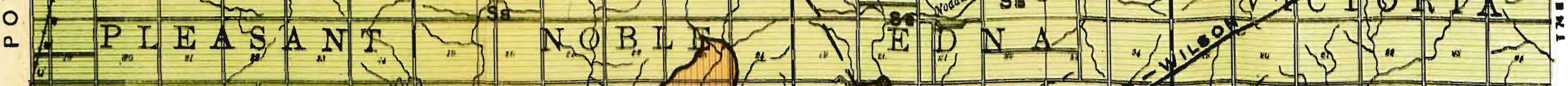

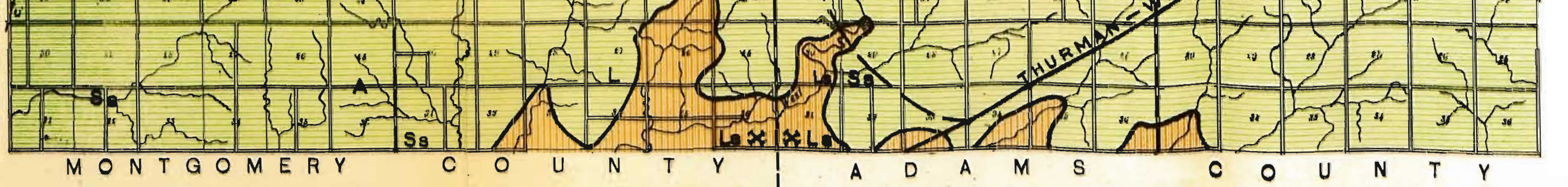

